\title{
HUMAN COMMUNITY: TOPICAL ISSUES OF THE SCIENTIFIC RESEARCHES
}

Collective monograph

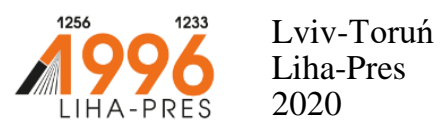




\section{Reviewers:}

Prof. nadzw., dr hab. Stanistaw Kunikowski, Rektor of Cuiavian University in Wloclawek (Republic of Poland);

Prof. dr hab. Joanna Marszałek-Kawa, Uniwersytet Mikołaja Kopernika w Toruniu / Nicolaus Copernicus University (Republic of Poland).

Human community: topical issues of the scientific researches : collective monograph / K. S. Brenzovych, N. R. Holubiak, M. M. Korol, M. M. Palinchak, etc. - Lviv-Toruń : Liha-Pres, 2020. - 108 p.

ISBN 978-966-397-219-0

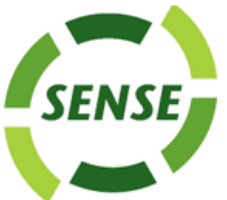

Liha-Pres is an international publishing house which belongs to the category "C" according to the classification of Research School for Socio-Economic and Natural Sciences of the Environment (SENSE) [isn: 3943, 1705, 1704, 1703, 1702, 1701; prefixMetCode: 978966397]. Official website www.sense.nl. 


\section{CONTENTS}

THE AMERICAN SEGMENT

OF GLOBAL MIGRATION PROCESSES

Brenzovych K. S.

PUBLIC CONTROL OF PUBLIC AUTHORITIES:

SIGNIFICANCE FOR UKRAINE

Holubiak N. R.

.22

CURRENT STATUS AND ANALYSIS OF CHINA'S REGIONAL AND BILATERAL TRADE AGREEMENTS

Korol M. M.

RELIGION AND CHURCH IN CENTRAL

AND EASTERN EUROPE

Palinchak M. M.

.58

LUGANIAN CHARACTER TWENTY YEARS LATER:

NECESSARY CORRECTION

Yeremenko O. M., Kroytor A. V. 82 



\section{THE AMERICAN SEGMENT OF GLOBAL MIGRATION PROCESSES}

\section{Brenzovych K. S.}

\section{INTRODUCTION}

Global migration processes are showing striking dynamics. From 1990 to 2017 , the number of international migrants increased by 105 million, or $69 \%$. In 2017, there were 258 million migrants worldwide, and $57 \%$ of them were moving to developed countries. In other words, every $29^{\text {th }}$ person in the world is a migrant and lives outside his or her motherhood ${ }^{1}$.

Influenced by the globalization, economic integration, scientific and technological progress the geographical flows of population movements are being transformed, number of migrants is growing; new types of migration and factors that cause it are emerging. In today's world, migration is already considered as a normal, natural process of redistribution of human capital. A particularly important role of population movements in the intellectualization of the economic potential of the world economy should be underlined.

Migration is mostly driven by economic factors, such as search of ways to improve one's well-being and the intention of finding place, where the one's labor will be used in the most efficient way. Labor as one of the most mobile factors of production, tends to center where its use will be most effective. Therefore, labor migration flows tend to be directed towards countries with high levels of productive forces development.

The American region, consisting of developed Northern America, represented by the USA and Canada, and less developed Latin America, (another approach is to divide Americas for North, inclusing Mexico, Central and Southern parts) is an interesting study object from the point of variety of types, motives and corridors of migration. The region is characterized by significant differentiation of levels of economic development of the coutries, differences in national political systems. The assessment of migration processes within the former NAFTA (followed by USMCA) will allow to reveal the effect of regional economic integration factor in the distribution of migration flows.

${ }^{1}$ United Nations, Department of Economic and Social Affairs, Population Division (2017). International Migration Report 2017. URL: https://www.un.org/en/development/desa/population/ migration/publications/ migrationreport/docs/MigrationReport2017_Highlights.pdf 


\section{General features of migration processes in the Americas}

Military conflicts, international contradictions, environmental disasters are also among the factors causing the worldwide movement of population. In the face of local military and political conflicts, or worsening criminogenic situation in certain regions of the world, the migration growth is also happening between the neighboring countries and countries, which are close in terms of development of productive forces, levels of average per capita income, or are approximated by historical and cultural characteristics.

The consequences of migration processes for hosting countries and countries of emigration also differ, as the influence of immigration on the economy of the country depends on the structure of migration flows and motives for migration. Thus, constant and relatively small-scale incoming movement of the working age population, motivated by the desire to find job and stay in the hosting country for a longer time, willingness to be integrated into a socio-economic environment of the country, can contribute to economic growth in the hosting country. It has been calculated, that increase in the foreign-born population by one percentage point elevates income per capita by approximately six percent in the long-run ${ }^{2}$.

On the other hand, emigrtion from the country with a high unemployment level, can temporarily reduce social tension at the local labor market and increase foreign exchange earnings in the form of migrant transfers to the country. However, uncontrolled flow of youth and children (the categories that most often leave their homeland due to the political or environmental crisis), threaten the host country with destabilization of the socio-demographic situation. It may cause increased tax burden on the working population of the country, because of growing expenditures on social services, unemployment benefits, education and medicine, housing construction for immigrants. Therefore, the larger and more diverse the composition of the countries belonging to the investigated macro region, the more differences in the levels of their development - the more difficult it is to make generalizations about the impact of migration on its development, the greater are the features and differences between migration processes in certain countries.

Traditionally, Western Europe, Northern America, Australia, the Middle East's oil-exporting countries and other global or regional leaders in terms of economic and social development, are also among the major centers of gravity for migration in the modern world. The main flows of international migrants are directed to those countries, and the share of foreign migrants in the population structure is much higher than average in the world. Migrant concentration is the

${ }^{2}$ Estevadeordal Antoni. Latin America: The opportunity of migration. June 14, 2019. URL: https://theglobalamericans.org /2019/06/latin-america-the-opportunity-of-migration/. 
highest in such coutries as: the UAE in the Middle East, Gabon in Africa, in the USA in America, Switzerland in Europe, Australia in the Asia-Pacific region. As can be seen from Figure 1, the largest number of migrants in the world is coming from Asia (over 80 million), Europe (78 million), North America (58 million). Europe and North America have a positive migration balance and together host two-thirds of international migrants. The Latin American region has the largest negative migration balance among all regions of the world (over 39 million people in 2017). According to report of International Organization for Migration, with only $7.2 \%$ of the total global population (over 550 million inhabitants in 2014), the region of North America, Central America and the Caribbean hosts about $25 \%$ of all migrants in the world and experiences unique migratory flows ${ }^{3}$.

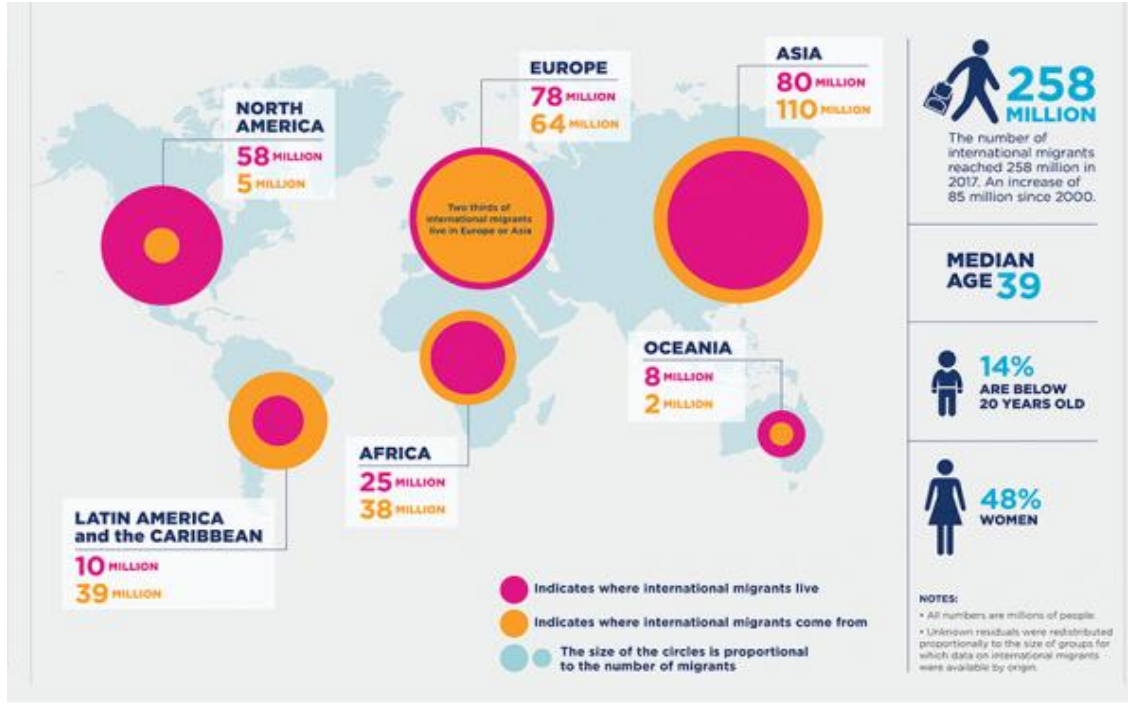

Figure 1. Number of international migrants in $2017^{4}$

The United States, as the undisputed economic leader of the region, is also the largest recipient of migrants in the world. In 2017, the country became a new home to 49.8 million migrants, or $19 \%$ of all migrants in the world. According to data of the US Citizenship and immigration service, more than

${ }^{3}$ Central and North America and the Caribbean. URL: https://www.iom.int/central-andnorth-america-and-caribbean.

${ }^{4}$ International migrant stocks. Migration data portal. URL: https://migrationdataportal.org/ themes/international-migrant-stocks 
700000 persons are naturalized in the US yearly. In 2018, the Immigration service received more than 8.7 applications from foreign citizens. Quarter of them were asking for official employment authorization ( 2.1 million), more than 750000 were naturalized, and more than 1 million persons have their temporary residence approval ${ }^{5}$.

The methodology of the Internation Labor Organization examines global migration flows in the context of migrant movements:

1) According to the direction of migration between the parts of the world 'from - to' (North - North, South - South, North - South, South - North);

2) According to the movement of migrants between regions of the world in their different combinations (Europe-Asia, Asia-Europe, Latin AmericaNorth America, etc.).

Analysis of the data by the first approach makes it possible to determine the following breakout of migration flows within the Americas: South-South destinations account for $38 \%$ of international migrants, about $34 \%$ goes to South-North direction, $22 \%$ of migrants move from North to North, and 5\% from North to South. In addition, over a quarter of all migrants in the world accounted for North (USA, Canada) and Latin America (the rest of the countries, including Mexico). $23 \%$ of all migrants went to North America, $4 \%-$ to Latin America ${ }^{6}$.

Data estimation by regional migration corridors by number of migrants also shows that Latin America-North America is one of the biggest migration corridors in the world. It takes fourth position after Asia-Asia, Africa-Africa, Europe-Europe corridors. In addition, Mexico-US bilateral migration corridor is among the top 10 corridors with the highest average growth rate of migrants in 2010-2017.

Flows within the American region (Including Northern and Latin Americas) should be considered in two conditional directions in terms of the proximity of the levels of economic development of countries:

1. "Horizontal" - migration between countries, which are close in terms of economic and social development. That is, between the developed US and Canada, or between the underdeveloped Latin American countries;

2. "Vertical" - includes upward (or "bottom up" migration - migration flows from less developed countries of Latin America to the USA and Canada),

${ }^{5}$ US Citizenship and Immagration Services report 2018. URL: https://www.uscis.gov/ sites/default/files/USCIS/statistics/2018_USCIS_Statistical_Annual_Report_Final_-_OPQ_5.28.19_ EXA.pdf

${ }^{6}$ United Nations, Department of Economic and Social Affairs, Population Division (2017). International Migration Report 2017. URL: https://www.un.org/en/development/desa/population/ migration/publications/migrationreport/docs/MigrationReport2017_Highlights.pdf 
or downward ("from top to bottom", as from the developed USA and Canada to Mexico, or to countries of Latin America).

In the case of horizontal migration between the United States and Canada, the movement of the population is mainly happens due to intellectual migration (migration of highly skilled workers, young people for the purpose of education). Horizontal migration between underdeveloped Latin American countries, in addition to economic factors, is also determined by security aspects (people are moving from regions affected by local conflicts and from areas with a negative criminogenic situation to more safe and stable regions) and ecological aspects (natural disasters).

Table 1 provides detailed information on migratory flows within the Americas (excluding small island territories). The country of origin of the migrants is delayed horizontally, while the country of destination is shown vertically. Thus, the intersection of the columns shows information on the movement of migrants from one country to another (the number of migrants from a given country of origin in the hosting country as of the end of 2017 year).

The top-10 migration corridors within the Americas (North, South, Central and Caribbean) as of the number of migrants are:

1) Mexico-USA (12 680 thousands);

2) Dominican Republic - USA (1 070 thousands);

3) Venezuela - Columbia (990 thousands);

4) USA - Mexico (900 thousands);

5) Canada - USA (890 thousands);

6) Haiti -USA (670 thousands);

7) Haiti-Dominican Republic (340 thousands);

8) USA-Canada (310 thousands);

9) Costa Rica - Nicaragua (290 thousands);

10) Chile - Argentina (220 thousands).

Within these ten corridors, the share of migrations from the USA to Canada and from Canada to the USA comprise only 7\%, while migrations from the countries of South and Central America (mostly Mexico) to the developed USA and Canada - 83\%, the rest migrations happen between the countries of the Central and Southern America and to Mexico. Almost $15 \%$ of the population of North America is foreign-born. In fact, about $72 \%$ of all migrants born in Latin America and the Caribbean reside in North America, the vast majority of which are from Mexico and Central America ${ }^{7}$.

${ }^{7}$ Central and North America and the Caribbean. URL: https://www.iom.int/central-andnorth-america-and-caribbean. 


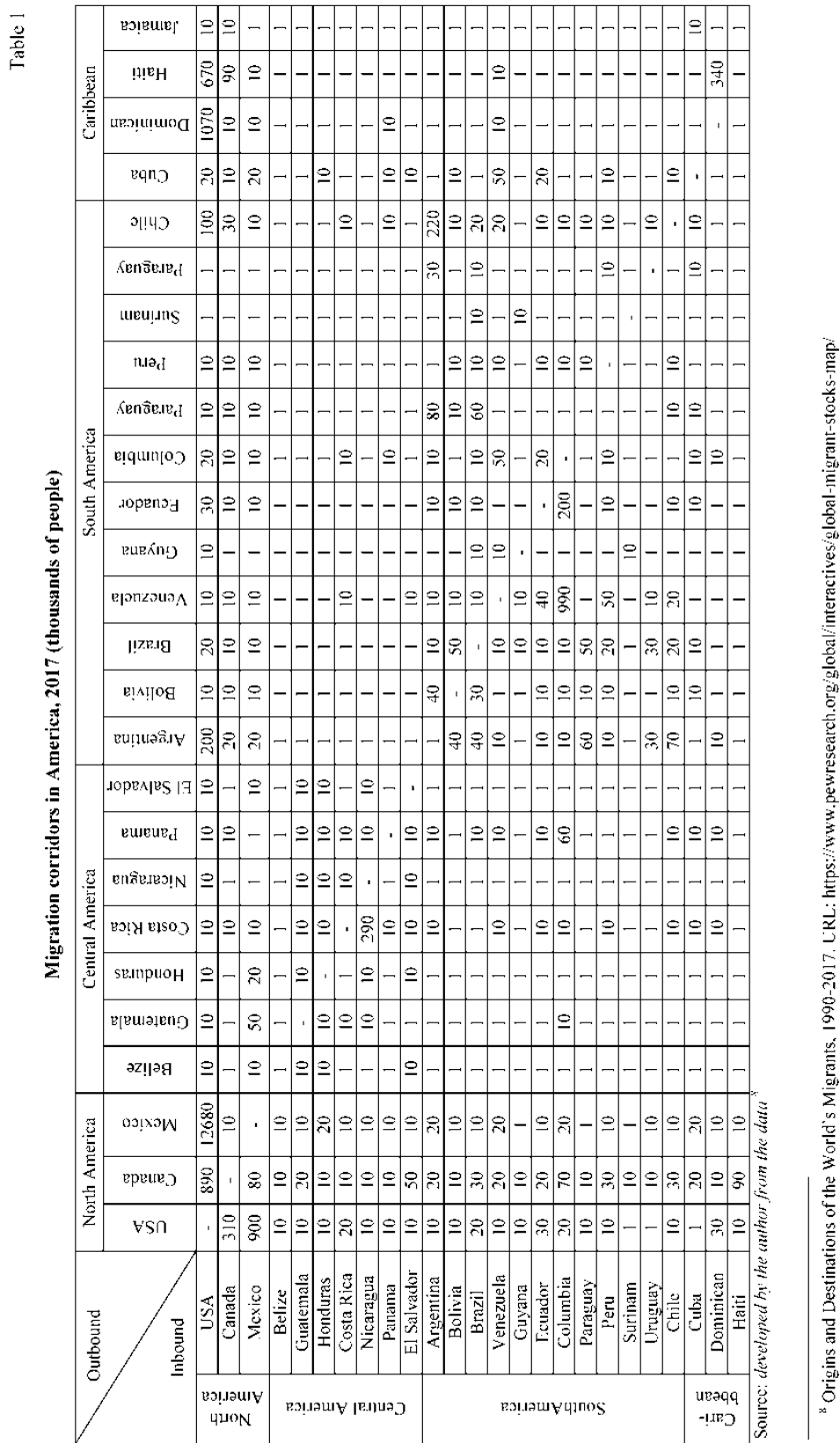


The issue of emigration from the US is rather rarely discussed in the scientific literature, as the US is traditionally considered an a country of immigrant, leading hosting country in the world. The positive migration balance is about 47 million people (as of 2017, over 3 million Americans resided outside the United States, while nearly 50 million foreigners resided in the United States). Mexico hosts the most migrants from the developed United States and Canada - more than any other country in the region (more than 1 million Americans and Canadians lived in Mexico in 2017). Mexico has also an unofficial status of an "illegal migration corridor", a transition point for people moving to the developed United States and Canada from the rest of Latin America.

Thus, the study migration flows in America as part of the world process should be considered in the following contexts:

1) Mutual migration between the economically developed US and Canada - predominantly "family" migration, including affluent families, politically driven migration, and intellectual (student and skilled);

2) migration in the US-Canada-Mexico triangle;

3) migration from Latin American countries (except Mexico) to the USA and Canada;

4) internal migration in the Latin American countries, and in particular the migration crisis caused by the socio-economic crisis in Venezuela.

\section{Migration in the USA-Canada-Mexico triangle}

Migration flows between the US and Canada are traditionally driven by economic factors. The number of Canadian residents who move to the US almost three times exceed the number of US citizens who are migrating to Canada. The structure of American migration to Canada is stable and involves, for the most part, households which are looking for more comfortable living conditions, or have to reside in the USA due to change of place of work or for the study purposes. No language barrier, democratic migration legislation, and a supportive social environment facilitate the easy and comfortable coming of American citizens to permanent or temporary residence, work or study.

The victory of Republican D. Trump at the US presidential elections has somewhat altered the trajectory of migration between these countries and has led to a significant increase in the number of migrants from the USA. In less than a year of the Republican presidency, the number of people who left the US for Canada increased by 2000 persons. In 2017, more than 1,000 Americans received Canadian citizenship, and the number of US student visas issued by the Canadian government increased too.

Even with relatively small quantitative changes, given the overall magnitude of migration from the US, experts see it as a rather threatening trend. 
Similar growth in emigration from the United States due to political motives and disagreement with the basic foundations of the policies of the newly elected president and parliament have occurred before, but it is for the first time that these processes have such a significant scale?

During 2017-2018, procedures that are more complicated and more strict requirements were introduced for immigrants to the United States. That caused a significant increase in migration to Canada, mainly students and professionals from other countries who have previously studied or worked in the United States. Over 2017-2018, the number of international students in Canada has increased significantly (by $20 \%$ in $2017-2018$ and by $18 \%$ in $2018-2019$ ). The Canadian economy has received over $\$ 31$ billion from international students in $2017^{10}$.

Due to the introduction of harsh measures in the US migration policy, the new type of migrations - so-called "technical refugees" or high-tech visa applicants appeared in Canada. Those are foreign high-skilled workers who have been previously working for US companies in the US, and were forced to leave work because of a legal requirement or lack of favorable conditions for their families at the USA territory. Instead, American companies, reluctant to lose skilled workers, offer them jobs at their offices in Canada, where they may apply for citizenship and family benefits in the nearest future.

US companies are expanding their presence in the Canadian market so that they can easily hire skilled workers from other countries. Sixty-three percent of employers surveyed in the Envoy study are increasing their presence in Canada, either by sending more workers there or by hiring foreign nationals there. More than half of those did both. Another 65 percent of hiring professionals said Canada's immigration policies are more favorable to US employers than US policies. Of those surveyed, 38 percent are thinking about expanding to Canada, while 21 percent already have at least one office there ${ }^{11}$.

The share of Canadian citizens in the overall immigration structure to the US is only $2 \%$, and their number has remained virtually unchanged for almost 40 years. However, the USA remains the main migration corridor for Canada ${ }^{12}$.

The USA is an undoubtable global and regional immigration center. The U.S. foreign-born population reached a record 44.4 million in 2017 (Figure 2).

${ }^{9}$ About 2,000 more Americans than normal have moved to Canada since Trump's election. Global news. URL: https://globalnews.ca/news/4396938/move-to-canada-donald-trump/

${ }^{10}$ Top ten origin countries of international students at year's end in Canada in 2017. Statista. URL: https://www.statista.com/statistics/555132/top-10-origin-countries-of-internationalstudents-at-years-end-canada/.

${ }^{11}$ Canada is becoming a tech hub. Thanks, Donald Trump! URL: https://www.vox.com/ 2019/3/19/18264391/us-tech-jobs-canada-immigration-policies-trump

12 Alperin E., Batalova J. Canadian Immigrants in the United States.Migration Policy Institute. URL: https://www.migrationpolicy.org/article/canadian-immigrants-united-states 
Since 1965, when U.S. immigration laws replaced a national quota system, the number of immigrants living in the U.S. has more than quadrupled. Immigrants today account for $13.6 \%$ of the U.S. population, nearly triple the share $(4.7 \%)$ in 1970. However, today's immigrant share remains below the record $14.8 \%$ share in 1890, when 9.2 million immigrants lived in the U.S ${ }^{13}$.

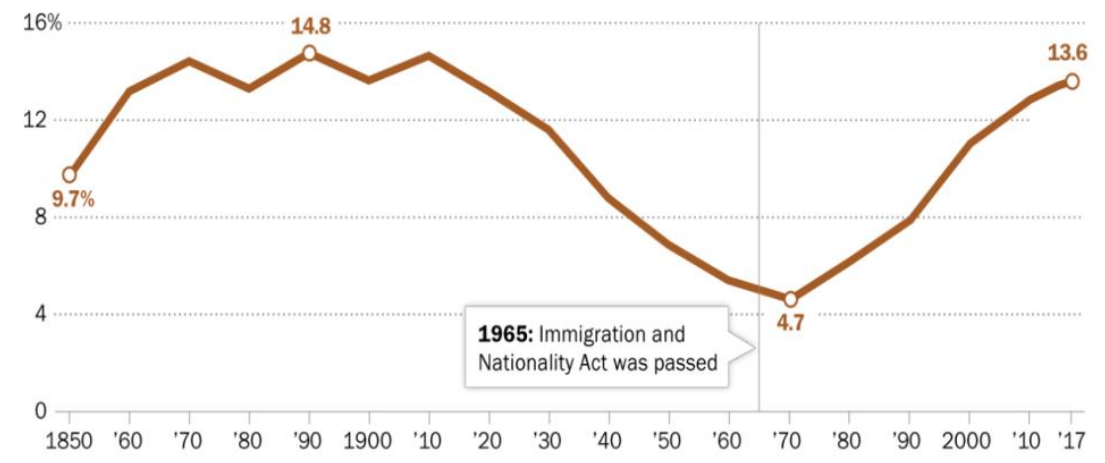

Figure 2. Immigrant share in the USA population, 1850-2017, \%

Source: Radford Jynnah. Key findings about U.S. immigrants (2019)

The dynamics of migration to the United States over the past half century indicates significant changes. First, the geographical structure of immigration has changed. Whereas in 1960, the majority of migrants came from Europe and neighboring Canada (83\%), now $77 \%$ are Latin American and Southeast Asian nationals. Second, the duration of immigrant stay in the United States has increased. In 2017, $72.2 \%$ of immigrants had lived in the U.S. for over 10 years, up from 56.2\% in 1990 (but similar to the share in 1970). An increase in this figure correlates with an increase in the share of children born by migrants in the general population of the country, which is now $12 \%$ (according to the forecast, it will be 18\% in 2050). The level of English proficiency of migrants at a level sufficient for professional communication remains at the level of 1990th (only every second migrant is fluent in English), and $43 \%$ of immigrants in the US are Spanish. At the same time, the increase in the education level of migrants is a positive trend. About $17.8 \%$ of immigrants over the age of 25 have a bachelor's degree (compared to $13.7 \%$ in 2000), and $13.4 \%$ have a master's and doctoral degree.

${ }^{13}$ Radford Jynnah. Key findings about U.S. immigrants. Pew Research Center. URL: https://www.pewresearch.org/fact-tank/2019/06/17/key-findings-about-u-s-immigrants/ 
Though there is almost no detailed statistics available on the reasons why people are migrating to the US, the enquiries show that the improvement of financial situation remains the main reason for moving to the USA for $55 \%$ of respondents, while for $24 \%$ of them reunification with family is the goal ${ }^{14}$.

Canada, the second largest economic development in America after the United States, and is unique in terms of migration trends and migration policy. With the number of immigrants per capita being more than three times higher than in the USA, the country is much more loyal in the attitude of citizens to migrants, and the population growth which is reached mostly due to migrants, is not considered by the government as a negative trend. Canada's population grew by 168,687 in the second quarter of 2018 , of which $82 \%$, or 138,978 , was attributed to international migration. As can be seen from Figure 3, migration growth has far exceeded Canada's natural population growth since 1998.

The Government of Canada is considering immigration as a mayor driver of economic growth. Inbound migrations is seen as a way to tackle the problem of aging of population. Through governmental migration assistance programs, Canada intends to increase the worker-to-retiree ratio. The government creates favorable conditions for the arrival and employment of migrants in those professions whose shortcomings are most obvious (in the fields of health care, trade, science and maintenance). Canada has the highest migrant naturalization rate in the world - more than $86 \%$ of those applying for citizenship receive a positive response. In addition, effective policy migration has resulted ensuring the uniformity of migrant displacement. While in 1997 most $(90 \%)$ of economic migrants were concentrated in British Columbia, Ontario and Quebec, currently the share of other regions as centers of migrant residence reached $40 \%{ }^{15}$.

At the same time, Canada has a much lower level of illegal border crossings. Undoubtedly, the absence of a direct land border with Latin American countries and the the US serving as a "filter" to illegal border crossings are the obstacles to illegal migration.

Since Canada has less vulnerable borders, it has not had anywhere near the difficulties with irregular migrants. It is only recently, because of Trump's intention to send illegal immigrants home, that Canada is now seeing more than 50,000 asylum seekers illicitly crossing into Canada each year, mostly via a rural road in Quebec ${ }^{16}$.

${ }^{14}$ Radford Jynnah. Key findings about U.S. immigrants. Pew Research Center. URL: https://www.pewresearch.org/fact-tank/2019/06/17/key-findings-about-u-s-immigrants/

${ }^{15}$ Annual report to Parliament on Immigration 2018. URL: https://www.canada.ca/content/ dam/ircc/migration/ircc/english/pdf/pub/annual-report-2018.pdf.

${ }^{16}$ Smith, Stephen. International migration to Canada reached record levels in second quarter of 2018. Canada immigration newsletter. September 27, 2018. URL: https://www.cicnews.com/ 
Among the reasons why Canada has no significant problems with illegal migrants compared to the US are the particularities of regulating inward migration. Unlike the United States, where the President is unable to address the major issues of migration restriction alone without the consent of parliament, the prime minister of Canada has "virtually unimpeded in ruling on immigration totals and student and worker visas... Canadian immigration policy is unusual because it's dominated by the government and civil servants. The public is rarely engaged in meaningful ways" ${ }^{17}$ help create jobs in all countries of the Union, will reduce the level of illegal migration from Mexico to the United States.

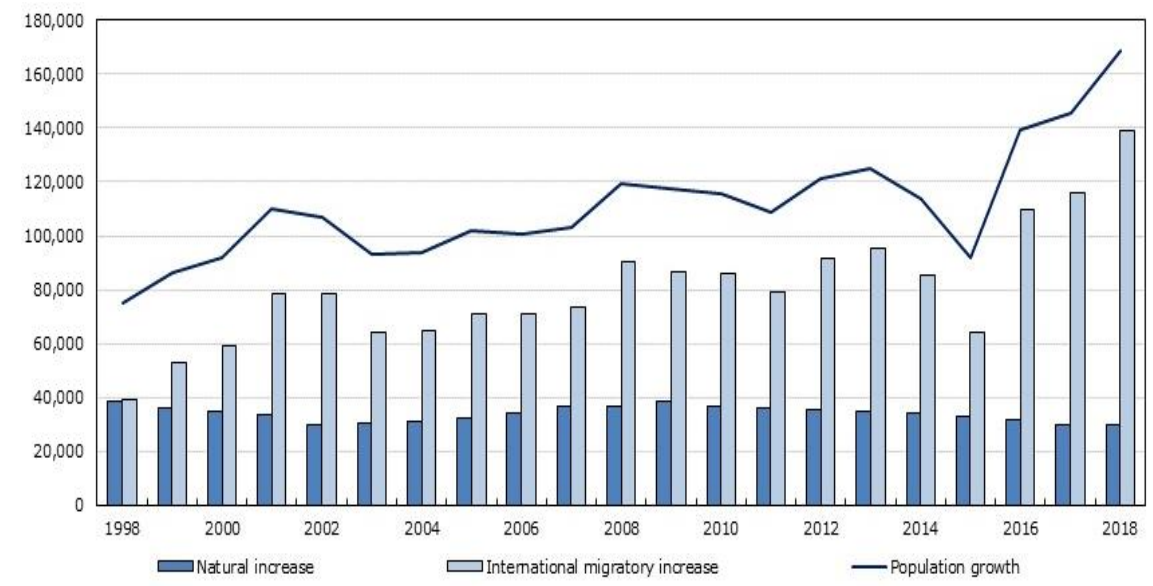

Figure 3. Factors of population growth in Canada, 1998-2018 ${ }^{18}$

The assessment of migration processes in America should take into account the impact of the conditions created by the NAFTA agreement. Yes, the purpose of the union was to abolish tariffs on mutual trade between the US, Canada and Mexico, liberalize trade in agricultural products, textiles and cars, protect intellectual property rights, introduce labor and environmental

2018/09/international-migration-to-canada-reached-record-levels-in-second-quarter-of-2018-

0911230.html\#gs.6eau54

${ }^{17}$ Douglas Todd: Canada vs U.S. on immigration: Five differences, five similarities. URL: https://vancouversun.com/opinion/columnists/douglas-todd-whats-different-and-similar-in-canadaand-u-s-immigration-policy

${ }^{18}$ Smith, Stephen. International migration to Canada reached record levels in second quarter of 2018. Canada immigration newsletter. September 27, 2018. URL: https://www.cicnews.com/ 2018/09/international-migration-to-canada-reached-record-levels-in-second-quarter-of-20180911230.html\#gs.6eau54 
standards. It was expected that the intensification of investment activities, expansion of production facilities will US government concludes significant losses to the US labor market through the action of the agreement and initiates the revision of the agreement. To confirm such a negative impact the US government shows that trade deficits with Mexico had eliminated 682,900 good U.S. jobs, most (60.8\%) in manufacturing, as jobs making cars, electronics, apparel and other goods moved to Mexico, and job losses piled up in the United States, especially in the Midwest where those products used to be made. Moreover, despite the expected decrease in immigration, the situation went opposite: while in 1990 only 4.5 million Mexican migrants were living in the U.S, by 2008 the number reached 12.67 million, which is roughly $9 \%$ of Mexico's total population. This was due, inter alia, to the introduction of a wide variety of types of work visas in the United States ${ }^{19}$. Other reasons for the increased migration from Mexico to the United States include the bankruptcy of more than 2 million Mexican farmers due to their inability to compete with highly efficient and heavily subsidized U.S. agriculture ${ }^{20}$.

With regard to Canada, the agreement had no significant impact on migration processes in the country, as trade liberalization facilitated the expansion of Canadian exports to the United States and job creation.

On April 18, 2017, President Trump signed the Buy American and Hire American Executive Order, which seeks to create higher wages and employment rates for U.S. workers and to protect their economic interests by rigorously enforcing and administering our immigration laws. However although the terms of the agreement were revised under the "Buy American and Hire American" idea, the Article 16 of the USMCA (NAFTA 2.0) concerning the granting of temporary work permits to migrants in the Union countries (TN Visa) remained unchanged. At the same time, the United States has taken a number of measures aimed at stabilizing the job cuts and encouraging US companies to hire Americans and expand production without moving it to Mexico. Thus $40 \%$ to $45 \%$ of car and truck parts have to be made by workers earning at least $\$ 16$ an hour. The goal is to level the playing field between American and Mexican autoworkers and to incentivize manufacturers to build more in the United States. The deal also mandates that $75 \%$ of a vehicle's parts must be made in North America, up from the current 62.5\% rule. Trump's administration argues that this will help incentivize billions in new auto sector production in the $\mathrm{USA}^{21}$.

\footnotetext{
${ }^{19}$ NAFTA, the Cross-Border Disaster. URL: https://prospect.org/article/nafta-cross-borderdisaster

${ }^{20}$ McBride J., Sergie M.A. NAFTA's Economic Impact. Council on Foreign Relations. October 1, 2018. URL: https://www.cfr.org/backgrounder/naftas-economic-impact

${ }^{21}$ What's new in the US, Canada and Mexico trade deal? URL: https://edition.cnn.com/ 2018/10/01/politics/nafta-usmca-differences/index.html.
} 


\section{The threats of migration crisis in Latin America}

The problem of migration from Central and South America is another aspect of migration processes in the Americas. It is one of the most discussed topics in the circle of national governments and international organizations. Experts say that the growth of migration processes within the region and the reduction of migration to the main recipients of migrants from Latin America - the US and Spain, occurred against the backdrop of the global financial crisis of 2008-2009, when these developed countries somewhat lost their "attractiveness" for immigrants. The crisis drove increases in intraregional flows and in these conditions, the more developed and stable countries in the region have improved their economic situation due to the influx of migrants from neighboring countries. In the case of Central America, poverty is a major factor in emigration, especially in Honduras and Guatemala, whose poverty rates stand at $74 \%$ and $68 \%$, respectively. The extreme vulnerability - particularly in rural areas - to climate events such as hurricanes, earthquakes and droughts, relatives residing and in other countries of the region are also contributing factors to intraregional migrations in America. Nearly $82 \%$ of migrants from NCA countries ("Northern Central America (NCA)" refers to El Salvador, Guatemala and Honduras) have family members in the United States, providing networks that support migration $)^{22}$.

There is migration toward countries with better economic development like Argentina, Chile, and to a lesser extent towards Brazil, because of the language. In the Colombian case, migration has slowed down, at least theoretically, due to the recent peace agreements, which are somewhat being undermined. Moreover, there is still a robust internal migration flow within the region, particularly involving countries like Venezuela, Colombia and Ecuador. In 2017, $16 \%$ of emigrants lived in other Latin American-Caribbean countries, down from $26 \%$ in 1990. Argentina was the top destination country for this group of emigrants, with 1.8 million people from other Latin American countries living there in 2017, up from 830,000 in $1990^{23}$.

Since 2015, migration processes in Latin America have become threatening, and the current stage of these processes is defined as a crisis. Central American countries are among the poorest in the world, while the United States is one of the richest countries with the largest economy in the world. Thus, according to the World Bank data, over $60 \%$ of Honduras's

${ }^{22}$ Economic Commission for Latin America and the Caribbean (ECLAC). Atlas of migration in Northern Central America (LC/PUB.2018/23). Santiago, 2018. URL: https://repositorio.cepal.org/ bitstream/handle /11362/44288/1/S1801071_en.pdf

${ }^{23}$ Latin America, Caribbean no longer world's fastest growing source of international migrants. Pew Research Center. JANUARY 25, 2019. URL: https://www.pewresearch.org/fact$\operatorname{tank} / 2019 / 01 / 25 /$ latin-america-caribbean-no-longer-worlds-fastest-growing-source-of-internationalmigrants/. 
population lives below the poverty line. One in five lives in poverty for about $\$ 1.90$ a day. Poverty levels are also rising in the other two countries - Mexico and El Salvador. They are also the main sources of migration to the United States, but in these countries this index is much lower - approximately $40 \%$ of people live below the poverty line ${ }^{24}$.

Thus, the largest number of migrants (legal and illegal) go to the United States. Although, according to the US Border Patrol, the overall number of detained migrants entering the country annually has dropped significantly (from $1,600,000$ people in 2000 to 400,000 in 2018, see figure 4), illegal migration through the South from Mexico and Central America is considered to be the greatest threat for the country's security. The lowest level of illegal migration was recorded in 2017 after the presidential election was won by D. Trump, known for his anti-migration rhetoric.

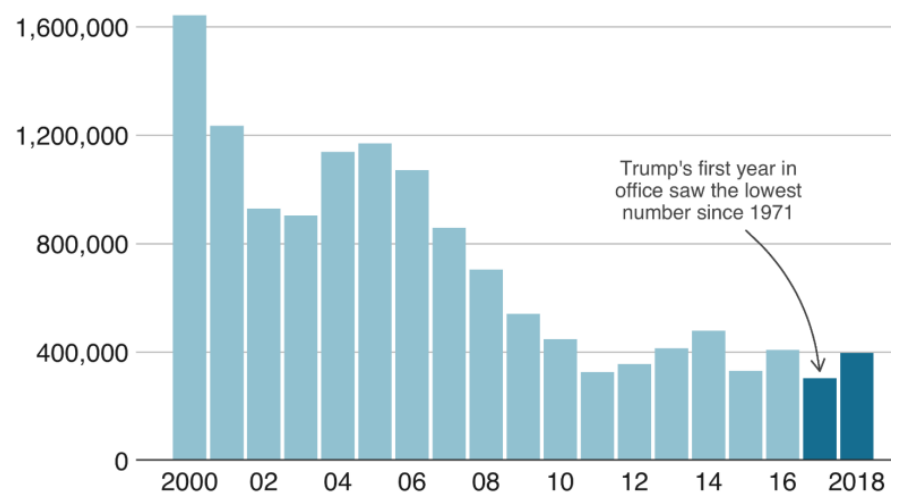

Figure 4. Apprehensions on US-Mexico border (2000 -2018), number of migrants ${ }^{25}$

According to US Border Patrol data, it has made 593,507 southwest border apprehensions from October 2018 to June 2019, which is almost twice more than in the previous US fiscal year $(303,916)$. The number fell dramatically in President Trump's first year but rose again last year. The number of migrants apprehended at the border surged in May to the highest level since 2006, with 132,887 detained - including 11,507 unaccompanied children. It was the first time that detentions had exceeded 100,000 since April 2007.

\footnotetext{
${ }^{24}$ Міграційна криза в США: пояснюємо, що відбувається. URL: https://www.bbc.com/ ukrainian/features-44572475.

${ }^{25}$ Is there a crisis on the US-Mexico border? URL: https://www.bbc.com/news/world-uscanada-44319094
} 
The migration in Venezuelian case is the most urgent problem in America and world as well. Venezuela is suffering from an acute socio-economic crisis. According to the Central Bank of Venezuela, hyperinflation in 2018 amounted to $130,000 \%$, while GDP decline was $23 \%$. Most people (64.3\%) had lost weight in $2017-11.4 \mathrm{~kg}$ on average, with the poorest losing most ${ }^{26}$.

The economic crisis that began in 2012, deepened after the election of President Nicolas Maduro, and was also connected with the fall of in oil prices, which is a major part of the country's exports. The short-sighted position of the country's leaders in public finances, including the increase in government spending on social goals, together with declining export earnings, has worsened all macroeconomic indicators.

Between 10 and $12 \%$ of Venezuelans currently live abroad in more than 90 countries. Traditionally, the majority were in Colombia, the United States and Spain - but Peru has seen the biggest influx since $2015^{27}$. Figure 5 shows the mayor migration flows from Venezuela.

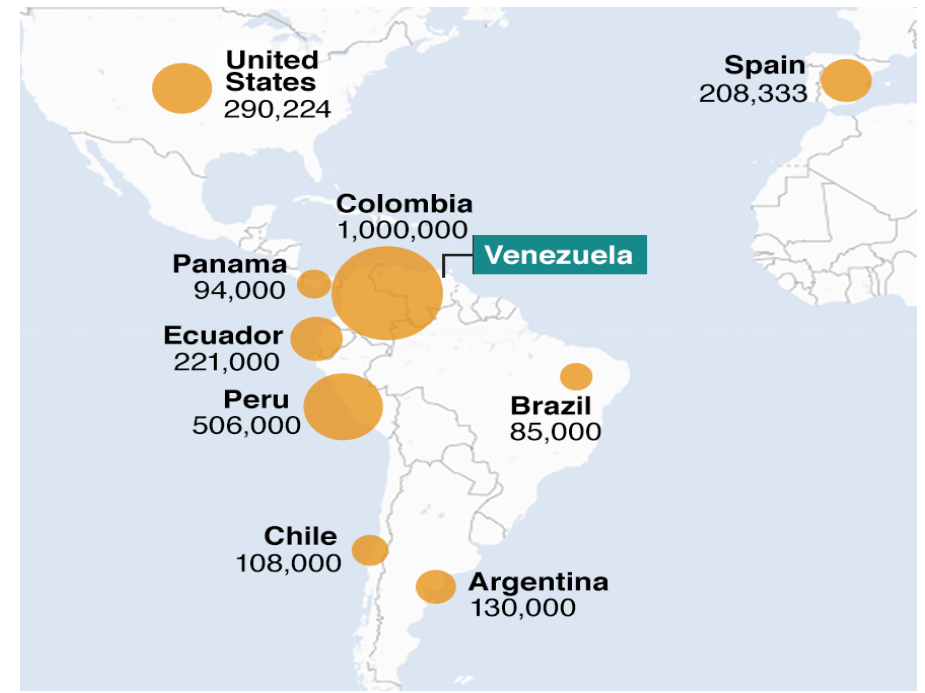

Figure 5. Main destinations for Venezuelan migrants in $2018^{28}$

26 Venezuela: All you need to know about the crisis in nine charts. URL: https://www.bbc.com/news/world-latin-america-46999668.

27 How the Venezuelan migration crisis affects South America. URL: https://www.straitstimes.com/world/americas/how-the-venezuelan-migration-crisis-affects-south-america

28 Venezuela: All you need to know about the crisis in nine charts. URL: https://www.bbc.com/news/world-latin-america-46999668. 
Thus, as of August 2018, 2.3 million Venezuelian people resided abroad, and by June 2019, this number had already increased to 4 million. Colombia hosted 1 million Venezuelans at the end of 2018, 221,000 persons were tempoparily staying in Ecuador, 506,000 in Peru ${ }^{29}$.

No more than $40 \%$ of Venezuelans outside the country have legal status or are registered as refugees, the rest are staying at the territories of other countries illegally. Until recently, neighboring Peru, Ecuador and Colombia favored refugees and allowed them into the country by internal passports. However in the summer of 2019, the governments of the country imposed stricter requirements for migrants to cross their borders.

In the context of relatively stable migration movements within Latin American countries, the influx of skilled workers into their countries contributes to their economic growth. On the contrary, in case the spontaneous flow of migrants who are now leaving Venezuela, the socio-economic tensions in the host countries are increasing and there is a real threat to their stability and safety. The negative impact of the Venezuelan migration crisis on Colombia is estimated at $\$ 1.5$ billion, which is $0.5 \%$ of the country's GDP. According to the World Bank report, the cost of additional education, health, water, early childhood, humanitarian, employment, and institution building services resulting from migration from Venezuela is estimated at between $0.2 \%$ and $0.4 \%$ of Colombia's GDP. This data will certainly increase given the growing number of persons leaving Venezuela ${ }^{30}$. Similarly, the government of Bolivia predicts that properly addressing the Venezuelan migrant situation will take about $\$ 550$ million, or 0.5 percent of the countries annual GDP from 2019 to $2021^{31}$.

The influx of refugees from Venezuela to other Latin American countries may have negative effect on the economic growth of hosting counties in the future. Therefore, the countries targeted by the major refugee flows from Venezuela are taking an active position in resolving the crisis and expressing support at the level of governments and international organizations. In this regard, the consequences of the migration crisis are considered in the short and long term and the solution of problems should be sought in two ways. On the one hand, the internal economic, social and demographic situation in countries with a threatened state of emigration should be stabilized in order to slow it

${ }^{29}$ Rocio Cara Labrador. The Venezuelan Exodus. July 8, 2019.URL: https://www.cfr.org/ article/venezuelan-exodus

${ }^{30}$ Axel van Trotsenburg. Facing an Unprecedented Migration Crisis in Latin America and the Caribbean. URL: https://www.worldbank.org/en/news/opinion/2019/03/29/america-latina-y-elcaribe-frente-a-una-crisis-migratoria-sin-precedentes

${ }^{31}$ Estevadeordal A. Latin America: The opportunity of migration. June 14, 2019.URL: https://theglobalamericans.org/2019/06/latin-america-the-opportunity-of-migration/ 
down. On the other hand, the prevention of the negative impact of immigration on host countries and the integration of refugees into national social systems should be addressed.

Migration risks in the region are also exacerbated by the fact that the region is one of the most unsustainable in environmental terms. In the close time of 20-30 years, according to the UN estimates, Latin America may face environmental migration. By 2050 in the face of overall increase in environmental migration, the displacement of the population due to unfavorable environmental conditions in the place of permanent residence may reach the volumes of labor migration. Thus eight countries in the region, seven in Central America and the Caribbean (Guatemala, Costa Rica, El Salvador, Nicaragua, Jamaica, Haiti, and the Dominican Republic) and one in South America (Guyana), are amongst the 25 countries most at risk of natural disasters. It is predicted, that changes in demographic trends will continue to incentivize migration from countries with higher fertility rates and a growing workforce, to countries with relatively older populations and labor market deficits ${ }^{32}$.

The issue of migration in Latin Americais is no longer regarded as a regional problem and is becoming the subject of debates, issue for funding programs by specialized organizations and agencies. According to the United Nations Refugee Agency (UNHCR), as of February 2019, the country's economic and social crisis had led to the exodus of 3.4 million persons. Therefore, the magnitude of this crisis makes it the second biggest globally after the Syrian crisis ${ }^{33}$.

Migration in Latin America is also considered in the context of achieving the 2030 Sustainable Development Goals - infrastructure, justice, poverty, hunger, equality between men and women, water, energy, employment, innovation, and peace. In particular, SDG 11 (sustainable cities and communities) is very relevant for migrants because cities and communities could develop a more welcoming environment for migrants, open to integration. Also goal 16 (peace, justice and strong institutions) and goal 17 (partnerships for the goals) are very important when it comes to migration ${ }^{34}$.

The deployment of the Syrian and Venezuelan crises has divided the world community into two camps. The result of such polarization were seen at the adoption of the UN Global Compact for Safe, Orderly and Regular

${ }^{32}$ Estevadeordal A. Latin America: The opportunity of migration. June 14, 2019. URL: https://theglobalamericans.org /2019/06/latin-america-the-opportunity-of-migration/

${ }_{33}$ Axel van Trotsenburg. Facing an Unprecedented Migration Crisis in Latin America and the Caribbean. URL: https://www.worldbank.org/en/news/opinion/2019/03/29/america-latina-y-elcaribe-frente-a-una-crisis-migratoria-sin-precedentes

34 Drivers of migration in Latin America. URL: https://www.caritas.eu/drivers-ofmigration-in-latin-america/ 
Migration (GCM), aimed at ensuring the safe, orderly and humane movement of people around the world. At the first stage of its adoption, the United States was the only country that did not agree to develop the text of the Agreement and discuss it. However, at the time of the final adoption of the treaty in December 2018, only 164 countries have endorsed the document at the UN General Assembly. According to the supporters of the Compact, who are basing from existing visions and estimates of the impact of migration on host countries, migration will facilitate the economic development of host countries due to the youth immigration; "rejuvenate" the structure of the hosting population. At the same time, the economies of countries of origin will be "supported" through money transfers made by migrants to their native countries.

Representatives of the countries opposed to the Compact (Czech Republic, Austria, Hungary, Slovakia, Latvia, Poland, Belgium, Bulgaria, Estonia, Slovenia, Italy, Switzerland, Ukraine) expressed fear that the implementation of the measures envisaged treaty may stimulate a new wave of migration, threatening peace and sovereignty of the host countries. Among the countries surveyed in the American macro-region, only the US and the Dominican Republic have declined the pact. It should be noted that both countries are currently facing the flows of illegal migrants from neighboring less developed countries (most migrants to the USA are coming from Mexico, while a great number of people coming to Dominican Republic are the citizents of Haiti).

\section{CONCLUSIONS}

The population of America (the America's) is just over $18 \%$ of the world's population, with migrants from the region making up $16 \%$ of the total international migrants. At the same time, the United States, belonging to the investigated here part of the world, is the country with the largest migrant population in the world of about 50 million foreigners. The US government, both at the level of internal decision-making and in dealing with the world community, argues that the influx of migrants poses a real threat to the national economy, denying participating in the drafting of a UN Global Compact for Safe, Orderly and Regular Migration. On the contrary, the neighboring Canada sees the international migration as a driver of further economic growth and actively supports immigration at the level of government programs.

The situation with the movement of the population in the poorest Latin American countries differs from the above. If, in relatively developed Mexico, emigration is largely economic in nature, then in the current political and economic crisis of Venezuela, the population movement already has a humanitarian motives - escape from persecution, famine, inhumane living 
conditions. The mentioned migration crisis in terms of the level of danger and the attention of the world community to it equates to the Syrian one and threatens the neighboring countries, which have so far freely and voluntarily received refugees from Venezuela, with significant economic losses. Like the Syrian one, it cannot be resolved without eliminating internal economic threats in the country. The flow of refugees will continue unless the the economic situation within the country will be stabilized and the consequences will certainly go much further across the borders of the region.

\section{SUMMARY}

The paper deals with the problem of intraregional migration in the Americas, including migration within the USA-Canada-Mexico triange under the influence of NAFTA agreement, upward migration from less developed countries of Latin America to the USA and Canada and gorizantal regional migration between the counrties of Latin America. Special attention is granted to the study of migration policy of the USA and Canada, as well as to policies of Latin American counrties, which are suffering from the flow of refugees of Venezuelian migration crisis.

The study shows that migration processes in the North America and the Latin America have different factors and outcomes. While the USA is struggling against the illegal migration from Mexico, Canada is approving most of the applications regarding the citizenship and is using migration as an instrument of economic growth. It is also found that the regional crisis in Venezuela is influencing the attitude to migrants in the global society.

\section{REFERENCES}

1. United Nations, Department of Economic and Social Affairs, Population Division (2017). International Migration Report 2017. URL: https://www.un.org/en/development/desa/population/migration/publications/ migrationreport/docs/MigrationReport2017_Highlights.pdf.

2. Estevadeordal Antoni. Latin America: The opportunity of migration. June 14, 2019. URL: https://theglobalamericans.org/2019/06/latin-america-theopportunity-of-migration/.

3. Central and North America and the Caribbean. URL: https://www.iom.int/central-and-north-america-and-caribbean.

4. International migrant stocks. Migration data portal. URL: https://migrationdataportal.org/themes/international-migrant-stocks.

5. US Citizenship and Immagration Services report 2018. URL: https://www.uscis.gov/sites/default/files/USCIS/statistics/2018_USCIS_Statisti cal_Annual_Report_Final_-_OPQ_5.28.19_EXA.pdf. 
6. United Nations, Department of Economic and Social Affairs, Population Division (2017). International Migration Report 2017. URL: https://www.un.org/en/development/desa/population/migration/publications/mi grationreport/docs/MigrationReport2017_Highlights.pdf.

7. Origins and Destinations of the World's Migrants, 1990-2017. URL: https://www.pewresearch.org/global/interactives/global-migrant-stocks-map

8. About 2,000 more Americans than normal have moved to Canada since Trump's election Global news. URL: https:/globalnews.ca/news/ 4396938/move-to-canada-donald-trump/.

9. Top ten origin countries of international students at year's end in Canada in 2017. Statista. URL: https://www.statista.com/statistics/555132/top10-origin-countries-of-international-students-at-years-end-canada/.

10. Canada is becoming a tech hub. Thanks, Donald Trump! URL: https://www.vox.com/2019/3/19/18264391/us-tech-jobs-canada-immigrationpolicies-trump.

11. Alperin E., Batalova J. Canadian Immigrants in the United States.Migration Policy Institute. URL: https://www.migrationpolicy.org/ article/canadian-immigrants-united-states.

12. Radford Jynnah. Key findings about U.S. immigrants. Pew Research Center. URL: https://www.pewresearch.org/fact-tank/2019/06/17/key-findingsabout-u-s-immigrants/.

13. Annual report to Parliament on Immigration 2018. URL: https://www.canada.ca/content/dam/ircc/migration/ircc/english/pdf/pub/annualreport-2018.pdf.

14. Smith, Stephen. International migration to Canada reached record levels in second quarter of 2018. Canada immigration newsletter. September 27, 2018. URL: https://www.cicnews.com /2018/09/international-migration-tocanada-reached-record-levels-in-second-quarter-of-2018-

0911230.html\#gs.6eau54.

15. Douglas Todd: Canada vs U.S. on immigration: Five differences, five similarities. URL: https://vancouversun.com/opinion/columnists/douglas-toddwhats-different-and-similar-in-canada-and-u-s-immigration-policy.

16. NAFTA, the Cross-Border Disaster. URL: https://prospect.org/ article/nafta-cross-border-disaster.

17. McBride J., Sergie M.A. NAFTA's Economic Impact. Council on Foreign Relations. October 1, 2018. URL: https://www.cfr.org/backgrounder/ naftas-economic-impact.

18. What's new in the US, Canada and Mexico trade deal? URL: https://edition.cnn.com/2018/10/01/politics/nafta-usmca-differences/index.html.

19. Economic Commission for Latin America and the Caribbean (ECLAC). Atlas of migration in Northern Central America (LC/PUB.2018/23). 
Santiago, 2018. URL: https://repositorio.cepal.org/bitstream/handle/11362/ 44288/1/ S1801071_en.pdf

20. Latin America, Caribbean no longer world's fastest growing source of international migrants. Pew Research Center. JANUARY 25, 2019. URL: https://www.pewresearch.org/fact-tank/2019/01/25/latin-america-caribbean-nolonger-worlds-fastest-growing-source-of-international-migrants/.

21. Міграційна криза в США: пояснюємо, що відбувається. URL: https://www.bbc.com /ukrainian/features-44572475.

22. Is there a crisis on the US-Mexico border? URL: https://www.bbc.com/ news/world-us-canada-44319094.

23. Venezuela: All you need to know about the crisis in nine charts. URL: https://www.bbc.com /news/world-latin-america-46999668.

24. How the Venezuelan migration crisis affects South America. URL: https://www.straitstimes.com /world/americas/ how-the-venezuelan-migrationcrisis-affects-south-america.

25. Rocio Cara Labrador. The Venezuelan Exodus. July 8, 2019. URL: https://www.cfr.org/article/venezuelan-exodus.

26. Axel van Trotsenburg. Facing an Unprecedented Migration Crisis in Latin America and the Caribbean. URL: https://www.worldbank.org/en/news/ opinion/2019/03/29/america-latina-y-el-caribe-frente-a-una-crisis-migratoriasin-precedentes.

27. Drivers of migration in Latin America. URL: https://www.caritas.eu/ drivers-of-migration-in-latin-america/.

Information about the author: Brenzovych K. S., $\mathrm{PhD}$ in Economics,

Associate Professor at the International Economic Relations Department, Uzhhorod National University 14, Universytetska str., Uzhhorod, 88000, Ukraine 


\section{PUBLIC CONTROL OF PUBLIC AUTHORITIES: SIGNIFICANCE FOR UKRAINE}

\section{Holubiak N. R.}

\section{INTRODUCTION}

The degree of development of civic society and the formation of good governance are strong indicators of democratic development of the country and approach to the stage of consolidated democracy according to the assessment of the project "Nations-in-transit" by "Freedom House". During the transformation period, many social and political issues of the country remain unchanged, such as the form of relations of civic society with public authorities; how open are the public authorities towards cooperation with the public; what is the level of involvement of citizens into political process; how important is the level of public trust in the state institutions.

History of state-building in Ukraine shows the obvious improvement in the development of civil liberties and civic activity of the population which appears particularly "acute" on the background of public protests, so-called "maidans" and becomes a reference point for future reforms. However, the next step to secure the effective change is the activation of mechanisms of public control in order to ensure real public involvement in the political process and political decisions. In other words, the phenomenon of control directly correlates with openness and transparency of policy, political trust and responsibility, level of political participation and political awareness of citizens.

Thus, the nature of "public control" is a part of civic society and the highest form of civic activity, as evidenced by the importance of the implementation of public control and the effectiveness of public control tools. Let us try answering the following questions: To what extent are the mechanisms of public control regulated in Ukraine? Who should carry out the public control? How significant are the results of public control for the political process? How do the problematic aspects and progressive changes in the controlling influence on public authorities correlate?

The European experience shows that this form of citizen participation in public administration can be successful and effective under the following next conditions: the need for public control as a form of public administration that provides feedback and external evaluation of decisions made; awareness of citizens, public organizations and territorial communities of their responsibility for the state; the existence of a developed legal framework that requires local 
governments to involve members of the public in the formulation and implementation of public policy; legislative regulation of the procedure for using public control mechanisms; providing professional training and professional development of public experts ${ }^{1}$. Therefore, there is an interdependence of good governance, social responsibility and civic position, as the lack of proper feedback leads to negative consequences and stagnation in the political system.

\section{Theoretical and conceptual understanding of "Public control"}

The concept of "control" is an interdisciplinary subject of study of social and human sciences (philosophy, sociology, law, management, political science). This issue originates in the studies of the classics of sociological thought as one of the main elements of the conceptual theoretical sociology. Social control serves as a generic concept for different varieties of control in society. The term "social control" was introduced into scientific circulation by French sociologist and psychologist G. Tarde to describe means of return to normal behavior, complied with the rules of society. In sociological interpretation, control is seen as a mechanism of self-regulation of the system that ensures the stable interaction, contributes to solving conflicts and prevents deviant acts ${ }^{2}$.

Control as part of the social system performs a regulatory function. Based on the nature of the interdependence of people and the need to act together, society shapes certain social roles and patterns of behavior. Consideration of a certain level of social communication actualized the reference to methods of symbolic interactionism. The order of life is the product of everyday interaction of people, including that on the political level. Interest in the procedural aspects justifies the use of the term "control" as one of the techniques for regulation of social relations. For example, American sociologist W. I. Thomas considers technique of group control as a social necessity, i.e. opposes it to the crisis of voluntary act through attribution of unwanted and the appearance of desired effects ${ }^{3}$. T. Shibutani assures of the importance of the study of social control, because human behavior is organized in response to the expectations that are attributed to others. It means that from the standpoint of

1 Середа Т. Стратегічні орієнтири взаємодії органів державного управління 3 громадськістю у процесі реалізації конституційно-правової реформи / Т. М. Середа. Теорія та практика державного управління. 2018. Вип. 2. С. 81.

${ }^{2}$ Корж К. М. Концептуалізація соціального контролю як технологічного засобу стримування соціальних відхилень соціологічних теоріях кінця XIX - початку XX століття / К. М. Корж. Актуальні проблеми соиіології, психології, педагогіки. 2011. Вип. 13. С. 32-41.

Політична думка XX - початку XXI століть: методологічний та доктринальний підходи: у 2-х т./ за заг. ред. Н.М. Хоми. Львів: Новий Світ-2000, 2016. Т. 1. С. 66. 
interactionism, result of the interaction consists not only in establishing aims or behavior under the influence of external factors, but also in a certain degree of consensus, sequence of mutual acceptance of roles ${ }^{4}$.

In the context of law, control is understood as a mechanism to maintain regulatory order; system of sanctions against violators; one of the foundations of the constitutional system; type of social control; part of the institute of democracy; activities of citizens while solving the national issues and so on. In particular, control is functionally performed on the brink of the concepts "act - norm" in form of identifying and bringing acts into compliance with norms on the one hand, and norms into compliance with acts on the other hand.

In political science, a subject of public control is treated as a derivative concept from the social contract theory, technology of feedback, tool of interaction between civic society and public authorities, communication mechanism, as the highest form of political participation.

In order to analyze the relations between civic society and state, let us turn to the paradigm of constructivism, which deals with public policy as a communication space for public activity and construction of political discourse. According to constructivists, changes in the principles of operation of public institutions increase the mobilization capacity of social communities. It means that emphasis on the mode of communication between public authorities and the public not only reflects the level of relations, but plays an important role in its changing and openness 5 .

In particular, Karl Popper regards public control as one of the main features of democratic political regime. In his book "The Open Society and its Enemies", the researcher wrote: "By democracy I do not mean something as vague as "the rule of the people" or "the rule of the majority", but a set of institutions (among them especially general elections, i.e., the right of the people to dismiss their government) which permit public control of the rulers and their dismissal by the ruled, and which make it possible for the ruled to obtain reforms without using violence, even against the will of the rulers"6.

Theoretician of communicative process J. Habermas pays particular attention to the creation of a large number of "public spheres", which allow citizens of the XXI century using open communication in public institutions to control state power at various levels and vast territory which would guarantee their civic rights. "Development of all forms of influence on government

${ }^{4}$ Політична думка XX - початку XXI століть: методологічний та доктринальний підходи: у 2-х т. / за заг. ред. Н.М. Хоми. Львів: Новий Світ- 2000, 2016. Т. 1. С. 73.

${ }_{5}^{5}$ Поцелуйко А. О. Образ держави в соціальному конструктивізмі та структурному функціоналізмі / А. О. Поцелуйко. Грані. 2015. № 7. С. 36.

${ }^{6}$ Поппер К. Відкрите суспільство та його вороги / пер. 3 анг. О. Коваленко: в 2 т. К. : Основи, 1994. Т. 1. С. 179. 
requires constant self-criticism and self-control, since democracy will carry out all its functions accordingly only under conditions of constant "public censor"

A strong civic society, and not the state is the guarantor of the formation and development of democratic institutions. According to L. Diamond, the first and primary function of civic society is to provide a basis for limiting state power, and thus for society controlling the state. In his opinion, an important aspect of quality of democracy is active and pluralistic civic society, in which citizens take seriously not only their responsibility to express their interests and values, but also the control of public authorities and the monitoring of their activities. This is a function of independent media, NGOs, think tanks and others ${ }^{8}$.

F. Fukuyama argues that people tend to pursue their own interest while being part of the public authorities, but the reason for this is the weakness of institutions for counteraction, prevention and control. The democratization process involves several necessary conditions, namely a high level of education in society, well-established data exchange, control of public authorities, and stability of the legal system. In other words, civic society is often forced to take over the functions of watchdog demanding accountability and transparency in government ${ }^{9}$. The American political scientist R. Inglehart stresses the importance of political culture and political trust, because "democracy is not attained simply by making institutional changes through elite-level maneuvering. Its survival depends also on the values and beliefs of ordinary citizens" $"$.

Western theoreticians of civil society A. Arato and J. L. Cohen define public control as an important part of state development, strengthening of its principles, institutions and regulations, which changes theoretical and methodological understanding of the interaction between man, society and the state. So, institute of control establishes the legal order and the principle of balance between the interests of society and government in a democratic regime ${ }^{11}$.

${ }^{7}$ Габермас Ю. Структурні перетворення у сфері відкритості: дослідження категорії «громадянське суспільство» / пер. $з$ нім. А. Онишко. Львів : Літопис, 2000. С. 68.

8 Даймонд Л. В напрямку демократичної консолідації. Глобальне відродження демократії / за ред. Л. Даймонда, М.Ф. Платтнера Львів; Ахілл, 2004. С. 292.

${ }^{9}$ Fukuyama F. What is Corruption? Against Corruption: a collection of essays : websites. URL: https://www.gov.uk/government/publications/against-corruption-a-collection-of-essays/ againstcorruption-a-collection-of-essays

${ }^{10}$ Инглхарт Р., Вельцель К. Модернизация, культурные изменения и демократия. Последовательность человеческого развития. М.: Новое издательство. 2011. С. 71.

${ }^{11}$ Коэн Д., Арато Э. Гражданское общество и политическая теория / пер. с англ. Мюрберг И. И. и др.. Москва : Весь мир, 2003. С. 34. 
The idea of control is central to the notion of democracy, since the ideal is one of giving kratos to the demos: giving maximal or at least significant control over government to the people. But it turns out that the notion of kratos or control is definable in various ways and that as the notion is differently understood, so the ideal of democracy is differently interpreted. Irish philosopher and political theorist, P. Pettit distinguishes between three different notions of popular control, arguing that only one is really suitable in democratic theory. Under the first conception of popular control, it means that the people have a causal influence on government; under the second, it implies that the people exercise intentional direction over government; and under the third (institutional control), it requires that the people enjoy an intermediate degree of power. That the only plausible candidate for interpreting the ideal is that of institutional control ${ }^{12}$.

As for the participation of citizens in managing state affairs, we should mention the research by S. R. Arnstein "A Ladder of Citizen Participation", which substantiates the difference between formal participation and having the real power. The lower levels of "manipulation" and "therapy" describe the nonparticipation forms that substitute for the effective forms of influence. According to scientist, the highest step of civic administration is citizen control that allows citizens to get a majority in political decision-making or even full extent of power ${ }^{13}$.

Thus, the priority importance of control consists in creating the conditions for the stability of the system, directing social and political processes to openness and transparency, implementing positive changes. Therefore, control functions are based on a set of rules and values that are generated in the community and imply assessing the activity of authorities and ensuring fundamental rights and freedoms of citizens.

\section{Regulatory and procedural characteristics of Public control}

Maturity and degree of formation of civic society depends on the level of "public authorities-public" dialogue, state of development of institutes of direct democracy and their legality under current legislation. In our research, the importance of addressing public control as an influence tool is confirmed by its multifunctional purpose, namely performing diagnostics of the state of cooperation between authorities and civic society; elaborating practical recommendations for further development of public sector; developing prognoses of public policy and possible transformations.

${ }^{12}$ Pettit P. 2008, Three Conceptions of Democratic Control / P. Pettit. An International Journal of Critical and Democratic Theory, 2008. Vol. 15, No. 1, pp. 46-55.

${ }_{13}$ Arnstein Sh. R. A Ladder of Citizen Participation / Sh. R. Arnstein. Journal of the American Institute of Planners, 1969. No 35 (4), pp. 216-224. 
In Ukraine, it is necessary to single out the laws that directly regulate forms of public control and also the legislative acts that create conditions for implementing technologies of feedback between authorities and the public. It should be noted that the public control system includes inspection, verification, monitoring, examination and supervision of public authorities, local governments and their officials. However, only public examination is defined by law as the feedback procedure at the regulatory level. According to the adopted Governmental Resolution of Ukraine "On approval of the Order on promoting the public examination of activity of the governmental authorities" № 976 of November 5, 2008, public examination is defined as a component of democratic governance that allows civil society institutes and public councils to perform the evaluation of activity of executive authorities, efficiency of making and executing decisions, the preparation of proposals for solving socially important issues for consideration by the executive authorities in their work ${ }^{14}$.

The Constitution of Ukraine (Art. 38) guarantees the right of citizens to participate in the administration of state affairs, in All-Ukrainian and local referendums, to freely elect and to be elected to bodies of state power and bodies of local self-government ${ }^{15}$. The mechanisms of public control include direct forms of will expression of the public (elections, referendums, public hearings, petitions, mass-meetings, etc.) and indirect activities through public organizations $^{16}$. Some researchers identify direct (investigative journalism, access to information, public discussions, jury trials, citizens' legislative initiative) and indirect (public councils, the institute of Ombudsperson, associations of related structures) forms of public control ${ }^{17}$. Of course, these forms are regulated by the respective constitutional norms (freedom of information, individual and collective petitions, the right to participate in administration of state affairs) and specialized legislation, such as the Laws of Ukraine "About Local Self-Government", “On Public Appeal”, “On Information", etc.

It should be pay attention to the specific forms of implementation of public control in the areas of improvement of settlements; environmental protection and others. In particular, such control is exercised by public

14 Про затвердження Порядку сприяння проведенню громадської експертизи діяльності органів виконавчої влади: Постанова Кабінету Міністрів України від 5 листопада 2008 р. № 976. Офіційний вісник України. 2008. № 86. С. 100.

${ }^{15}$ Конституція України : станом на 1 верес. 2016 р. / Верховна Рада України. Харків : Право, 2016. 82 с.

${ }^{16}$ Стрілець Ю. П. Види і форми контролю в місцевому самоврядуванні / Ю. П. Стрілець. Теорія та практика держсавного управління. 2011. Вип. 3. С. 353.

17 Пухкал О. Г. Громадський контроль як важливий чинник демократизації та ефективності державного управління / О. Г. Пухкал. Інвестиції: практика та досвід. 2010. № 14. C. 56. 
inspectors. This is largely due to the fact that the effectiveness of public control in these areas requires a certain level of skills.

The subject of public control in the mechanism of public administration has two meanings. The first is the total large number of subjects exercising public control in the public-legal sphere, the second is that every sphere of government is the subject of public control by several subjects, or even every citizen $^{18}$.

Different interpretations of forms and subjects are primarily due to the lack of uniform regulation of the institute of public control. For example, the draft Law of Ukraine “On Public Control” (№ 2737-1 of 13.05.2015) considers the following measures of public control: analytical and monitoring investigations; public examination; verification ${ }^{19}$. Draft law № 4697 of 14.04.2014 includes the following mechanisms of public control: access to information; creation and operation of public control organizations; participation of subjects of public control in the work of advisory bodies; individual and collective petitions; submission of requests by citizens; implementation of general and special procedures of public control, etc; the separate article highlights general (hearing reports on the results of work, public hearings, public monitoring) and special (public examination, verification and investigation) procedures ${ }^{20}$.

The last issue was initiated in 2018 by People's Deputy of Ukraine S. Kaplin. In particular, he prepared a draft law of Ukraine № 9013 of 07.08.2018 "On civil control over the activities of the authorities, their officials and services", which was submitted to the Committee on Legal Policy and Justice of the Verkhovna Rada of Ukraine. That is, instead of the concept of public, the term civic control is introduced, the content of which is civic control over the activity of the authorities, their officials. The draft law changes the conceptual approach to public control, its tasks, methods, mechanisms of implementation $^{21}$. All this does not contribute to the integrity and systematic character of public control.

However, let us note some progress in taking into account the interests of citizens during implementation of administrative decisions associated with the Law of Ukraine "On principles of prevention and combating corruption"

18 Кравчук В. Полісуб'єктність громадського контролю у механізмі державного управління/ В. Кравчук. National law journal: theory and practice. 2016. № 5 (21). C. 11-15.

19 Проект Закону України «Про громадський контроль» від 13.05.2015. № 2737-1 URL: http://w1.c1.rada.gov.ua/pls/zweb2/webproc4_1?pf3511=55101

${ }^{20}$ Проект Закону України «Про громадський контроль» від 14.04.2014 № 4697. URL: http://w1.c1.rada.gov.ua/pls/zweb2/webproc4_2?pf3516=4697\&skl=8

${ }^{21}$ Проект Закону України «Про громадянський контроль за діяльністю органів влади, їх посадових і службових осіб» від 07.08.2018 № 9013. URL: http://w1.c1.rada.gov.ua/ pls/zweb2/webproc4_1?pf3511=64506 
(2011, repealed in 2016), which provides for performing the public anticorruption examination, public discussion of legislation on giving preference to economic entities, etc. ${ }^{22}$. In addition, the conditions for performing public control are created by the Law of Ukraine "On Access to Public Information" (2011), the approval of the Concept of the draft Law of Ukraine "On Fundamentals of the State Communication Policy" (2010).

The new stage for normative regulation of public control started after the Revolution of Dignity, which demonstrated a higher level of civic selforganization and activity. The so-called "loud laws", namely "On Cleaning Power" (2014), "On the Open Use of Public Funds" (2015), "On Prevention of Corruption" (2015), embody the principles of "publicity, transparency and openness", lay the foundation for electronic declaring of officials, citizen participation in the budget process at the local level, which provides for the access to information on the budgeting process and its implementation, determination of efficient use of public funds.

Since 15 July 2016, it was announced the process of disclosure and initiated the launching of the electronic asset declarations system for those persons authorized to perform public functions, either at national or local level. National, regional and local authorities, as well as members of their families, are obliged to disclose their assets (real estate, monetary funds, cash, loans, etc.) and to declare possible conflicts of interest (job position, contracting services, participation in the civil council, etc.). This data remains open and available on a single state database of asset declarations ${ }^{23}$.

Also we would like to draw attention to the recently adopted document "National Strategy for Civil Society Development in Ukraine in 2016-2020 years" approved by the Decree of the President of Ukraine on February 26, 2016. This strategy clearly defined in Part 4 "Strategic Directions and Tasks", which include ensuring effective procedures for public participation in the formation and implementation of state, regional policies, addressing issues of local importance and implementation of public control over the activities of the body ${ }^{24}$.

At present, the development of concepts of e-democracy, e-government and e-citizen is a promising direction for the institutionalization of public control over the activities of the state. Within these concepts the possibility of

22 Про засади запобігання і протидії корупції : Закон України від 07.04.2011 № 3206VI. Голос Украӥни. 2011. № 107.

${ }^{23}$ Ukraine: Handbook on Transparency and Citizen Participation. Partnership for Good Governance. Council of Europe. 2017a URL:https://rm.coe.int/handbook-ukraine-eng/168078406c

${ }^{24}$ Національна стратегія сприяння розвитку громадянського суспільства в Україні на 2016 - 2020 рр., затверджена Указом Президента України № 68/2016 від 26.02.2016 p. URL : http://www.president.gov.ua/documents/682016-19805. 
using information technologies by citizens is considered not only to participate in the management of state affairs, but also in solving the whole spectrum of public tasks. Development of information and communication sphere resulted in creating Internet platforms "E-Data", "Prozorro", "Open Budget", The Unified State Open Data Portal which embody the principle of "availability as a lever to influence those in power".

Success stories like the implementation of the e-platform ProZorro boosted transparency and competition in public procurement. The major step was made towards open data in Ukraine with the adoption of the Law "About changes to some law on access to public information in form of open data", which introduced significant changes in other relevant legal acts. These changes obliged public authorities and local governments to publish and regularly update public information in the form of open data ${ }^{25}$. A new attitude to the "active citizen" as a real subject and participator of political process, a bearer of sovereignty and a source of political power should be formed in these conditions.

Scientific studies often include the following causes of poor development of public control: closed nature of bureaucratized public authorities, lack of appropriate social base, lack of knowledge about the basic tools of influence on authorities, inability to use them or simple indifference of citizens with conformist behavior.

However, "the most painful" task of political reform remains the combat against corruption and public control over openness and transparency of the political process. According to the report by Freedom House (2017), the inability of the authorities to defeat corruption in high places undermines the popularity of the government and affects the efficiency of reforms in various fields ${ }^{26}$. Based on the results of new 2016 Corruption Perceptions Index, Ukraine received 29 points out of 100, which is two points more than last year's index and does not indicate a major breakthrough in the fight against corruption. Experts find the major challenges to be weakness of the institutions intended to enforce the rule of law, excessive over-regulation of the economy and concentration of power in the hands of oligarchic clans. Thus, it is evident that the progress of recent years has been largely driven by the reforms that were launched in 2014. However, lack of political will remains one of the main factors in curbing anti-corruption progress ${ }^{27}$.

${ }^{25}$ Ukraine: Handbook on Transparency and Citizen Participation. Partnership for Good Governance. Council of Europe. 2017a URL:https://rm.coe.int/handbook-ukraine-eng/168078406c

${ }^{26}$ Report of Ukraine. Freedom in the World. 2017. URL: https://freedomhouse.org/ report/freedom-world/2017/ukraine

27 Індекс сприйняття корупції. Transparency International Ukraine. URL: https://ti-ukraine.org/research/indeks-koruptsiyi-cpi-2016/ 
Let us use the example of sociological data to determine the efficiency and effectiveness of public control mechanisms according to three levels of public participation: access to information (basic right that does not imply active dialogue), consultations (authorities invite the public to discussions concerning certain decisions) and active civic engagement through dialogue and partnerships (including mutual responsibility at all stages of policy-making, starting with putting issues on the agenda and up to adoption and implementation of decisions $)^{28}$.

Monitoring of Ukrainian central executive bodies' websites in 2015 (70 websites analyzed) implemented by the "Regional Press Development Institute" NGO proved that despite some improvements in the level of information transparency of the aforementioned authorities (54,74 in 2015 in comparison to 49,6 in 2013 and 48,3 in 2012), 45,26\% of information related to activities of central executive bodies still remains unavailable for users. However, despite the rather slow increase in the level of website openness, the number of sites with an openness rate of more than $60 \%$ is significantly increasing. The most closed, as in previous years, is information on spending of budget funds, publication of reports on tenders and use of state property ${ }^{29}$.

As for transparency of data, the research "Data of Ukrainian cities: open data in progress" held by the Civil Network OPORA states that there has been some progress in 2016, namely 16 cities were registered on a unified portal of open data; 10 cities publish their data in separate sections on their websites, even though often in unopened format. However, half of the surveyed cities have done no administrative action to open data ${ }^{30}$. Thus, it should be noted that at the very first level Ukraine has established the initial conditions for openness, but produced no systematic policy on the availability of information and work in open data format.

As for consultation, authorities have standardized mechanisms for consultations under the Governmental Resolution of Cabinet of Ministers of Ukraine "On public participation in the formulation and implementation of public policy" of November 3, 2010, and the amendments of 2015 introduced a procedure for electronic communications ${ }^{31}$. The study "The Practice of Using

${ }^{28}$ Public Participation in Europe: An International Perspective" (EIPP, 2009) URL: http://www.partizipation.at/fileadmin/media_data/Downloads/Zukunftsdiskurse-

Studien/pp_in_e_report_03_06.pdf

${ }_{29}$ Відкритість української влади. Результати моніторингу веб-сайтів центральних органів виконавчої влади України - 2015. Інститут розвитку регіональної преси. URL: https://irrp.org.ua/vidkrytist_ukrainskoi_vlady/

30 Дослідження стану розвитку даних в українських містах за 2016 рік «Дані міст України: open data in progress». 2016. URL: http://uacrisis.org/ua/51882-opendata

31 Про забезпечення участі громадськості у формуванні та реалізації державної політики : постанова Кабінету Міністрів України від 03.11.2010 № 996. Урядовий кур’єр. 2010. № 84 . 
E-Democracy Tools by Civic Organizations in Ukraine" (2016) reflects the practical side: $60.2 \%$ of public activists would like to use e-consultations, but only $19.4 \%$ of respondents used electronic consultations in their work. This difference between desired and obtained is due primarily to insufficient level of computer literacy or lack of appropriate tool that will allow deepening public control ${ }^{32}$.

At the third level, namely the active involvement in policy-making, there is lack of initiative and ignorance of citizens of Ukraine on forms of influence on public authorities. According to the research (2018) by the Ilko Kucheriv "Democratic Initiatives" Foundation in collaboration with the Razumkov Center shows that only $7 \%$ of citizens are involved in active civic activity - in fact, the same as in $2013-(8 \%)$. Similarly, membership of NGOs and associations has not increased compared to 2013: $87 \%$ did not belong to any of the organizations, associations or parties in 2018 and in $2013-85.5 \%{ }^{33}$.

Therefore, the question arises about the deepening of political socialization and education of ordinary citizens and civic society activists in order to effectively use direct forms of democracy, to build social capital and to improve the level of trust in the government.

\section{Potential possibilities to promote Public control}

One of the forms of ensuring accountability of public authorities is the activity of public organizations and movements. Ukrainian practice of influencing the public authorities is minor, but the positive changes are tracked in activation of the third sector, increase of trust in them and constant monitoring of the dynamics of implementation of reforms.

Western democracies distinguish three types of public control organizations: "observers/supervisors", classic "watchdogs" and "proactive monitors". "Observers" mainly record changes in key areas of society and work on general theories without aiming to promote the results of monitoring in real public policy. In addition to the supervisory functions, "watchdog" organizations actively work with information channels and promote their research products, making authorities use their groundwork to improve policy, to reassess the effectiveness of programs, etc. "Proactive monitors" are often ahead of authorities and institutions at the level of ideas and solutions, and, in fact, create methods of solving social problems before critical situations arise ${ }^{34}$.

32 Практика використання інструментів електронної демократії громадськими організаціями в Україні. Результати експертного опитування. ГО «Подільська агенція регіонального розвитку». 2016. С. 9-10.

33 Громадянське суспільство в Україні: виклики і завдання (2018). URL: https://dif.org.ua/article/gromadyanske-suspilstvo-vukraini-vikliki-i-zavdannya

${ }^{34}$ Стрілець Ю. Принцип підконтрольності в контексті концепції “good governance" / Ю. П. Стрілець. Актуальні проблеми державного управління. 2011. № 2. С. 322. 
At the same time, more than 350 public organizations (both with the status and without the status of a legal entity) are registered in Ukraine, in the names of which the word "control" is used in various phrases "public control", "popular control", "democratic control", "anti-corruption control". In most of them the main focus of the activity of the mentioned NGOs is human rights; methodological advisory and information; socio-political; educational and cultural-educational functions ${ }^{35}$.

There are several organizations that provide oversight of the public sector, but each one controls a certain range of activities or exercises regional influence. Thus, NGO OPORA specializes in monitoring the electoral process and monitoring of party programs; Committee of Voters of Ukraine promotes the deepening of democratic reforms in the country through independent public monitoring of the election and referendum processes and lobbying of respective legislative changes.

Let us single out the development of public control network "Act!" (Ternopil, Vinnytsia, Zaporizhia, Kramatorsk, Mariupol) which deals with advocacy, public and legal education, consolidation of local public sector. This kind of organizations abroad gather information about activities of authorities, organize public information week, acquaint with the means of public control, conduct trainings, seminars and monitoring. They not only perform control functions (watchdog), but also contribute to the political socialization of the population $^{36}$.

Due to some progress in the formation of public space, there is a particular increase of public requests regarding control over the budgeting process, implementation of reforms, process of cleaning power ("lustration"). In order to establish dialogue between activists and local authorities, the project "Local Public Control over Budget Spending" was launched with a goal to inform about the adopted anti-corruption legislation and the new bodies that will be tracking and combating corruption ${ }^{37}$.

Providing an unbiased assessment of the activities of authorities is ensured by analytical nongovernmental organizations (think tanks), which monitor the current state and identify problems of public administration bodies. They are developing very dynamic in recent years in Ukraine while increasing

35 Кравчук В. Полісуб'єктність громадського контролю у механізмі державного управління / В. Кравчук. National law journal: theory and practice. 2016. № 5 (21). С. 13.

${ }^{36}$ Березовський Д. О. Аналіз основних проблем при використанні моніторингу та контролю в системі державного управління / Д. О. Березовський. Інвестиції: практика та досвід. 2015. № 4. С. 154-156.

${ }^{37}$ Громадський контроль за використанням державних фінансів на місцевому рівні. Міжнародний центр перспективних досліджень. URL: http://icps.com.ua/nashi-proekty/ aktualni-proekty-mtspd/hromadskyy-kontrol-za-vykorystannyam-derzhavnykh-finansiv-namistsevomu-rivni/ 
their institutional, expert and analytical potential. An important advantage of think tanks is their relative remoteness, independence and detachment of state and bureaucratic interests. According to the analytical report "Independent think tanks and government: is there any progress in bilateral cooperation?", leaders of non-governmental think tanks in Ukraine are Ukrainian Centre for Economic and Political Studies named after Olexander Razumkov, Ilko Kucheriv "Democratic Initiatives" foundation, Centre of Policy and Legal Reform (CPLR), International Centre for Policy Studies (ICPS) and the Reanimation Package of Reforms (RPR). These organizations are trying to offer a picture of the real condition in a given area that requires change, and to present the innovative qualitative ideas, concepts and policies regarding reforms of the main areas of national life just as carefully and impartially ${ }^{38}$.

Increasing public control is also due to international programs aimed at creating a culture of cooperation, raising public awareness, improving service delivery. For example, the project "Dissemination of best practices of nongovernmental monitoring of administrative services" aims to improve feedback, to strengthen the capacity of NGOs and to form the basis for organizational change; the program "E-governance for government accountability and community participation" aims to introduce innovative models of citizen engagement; the project "Strengthening the capacity of civil society organizations in the regions of Ukraine to influence the state authorities and local self-government in order to accelerate reforms" is oriented towards providing activists with the necessary knowledge to influence the public authorities. International Renaissance Foundation, the Civil Society Development Foundation, Matra programme, DESPRO are particularly active in this direction and fund the development of a number of programs aimed at creating a civic society.

\section{CONCLUSIONS}

Thus, the development of control functions of civic society will help public authorities to determine the priorities of political course, to meet the principles of good governance, to reflect the real state of social and political attitudes and support of political decisions by population. Although public control is advisory by its nature, the detection of violations or inconsistency by public authorities leads to the formation of public opinion, public and political attitudes and trust in government institutions.

On the part of the citizens, we should note that public control is intended to create conditions for the prevention of corruption and irresponsibility of

${ }^{38}$ Kermach R., Sukharyna A. Independent think tanks and government: is there any progress in bilateral cooperation? Analytical report. URL: http://dif.org.ua/uploads/pdf/ 36483373158dd0b040e0aa2.11421606.pdf 
public authorities, to provide access to the necessary data, to establish instruments for continuous feedback, to improve the mechanisms of social partnership of the public, government and business.

That is why the implementation of these conditions should start from the local and regional level, where people have the opportunity for direct management in their communities in order to satisfy public demands and needs. It will result in "better united groups, susceptible to responsibility", which increases the social capital of the state.

\section{SUMMARY}

This research deals with the public control and citizen participation as the key tools in the development of good governance. Both help to create the conditions for citizens to understand and evaluate the decisions which the government is taking on their behalf. The regulatory support of the institution of public control in Ukraine is analyzed. The faults and gaps in the current legislation of Ukraine related to realization of public inspection are identified. Particular attention has been paid to the characteristics of the practice and projects of public control in Ukraine.

Summarize, that citizens must be allowed access to documents, proceedings and data pertaining to any legislation enacted by that government. It is through accountability that citizens are able to control their government and allow society to progress.

\section{REFERENCES}

1. Березовський Д. О. Аналіз основних проблем при використанні моніторингу та контролю в системі державного управління / Д. О. Березовський. Інвестииії: практика та досвід. 2015. № 4. С. 154-156.

2. Відкритість української влади. Результати моніторингу вебсайтів центральних органів виконавчої влади України - 2015. Інститут розвитку регіональної преси. URL: https://irrp.org.ua/vidkrytist_ukrainskoi_ vlady/

3. Габермас Ю. Структурні перетворення у сфері відкритості: дослідження категорії «громадянське суспільство» / пер. 3 нім. А. Онишко. Львів : Літопис, 2000. 318 с.

4. Громадський контроль за використанням державних фінансів на місцевому рівні. Міжнародний центр перспективних досліджень. URL: http://icps.com.ua/nashi-proekty/aktualni-proekty-mtspd/hromadskyy-kontrolza-vykorystannyam-derzhavnykh-finansiv-na-mistsevomu-rivni/

5. Громадянське суспільство в Україні: виклики і завдання (2018). URL: $\quad$ https://dif.org.ua/article/gromadyanske-suspilstvo-vukraini-vikliki-izavdannya 
6. Даймонд Л. В напрямку демократичної консолідації. Глобальне відродження демократії / за ред. Л. Даймонда, М.Ф. Платтнера Львів; Ахілл, 2004. С. 290-304.

7. Дослідження стану розвитку даних в українських містах за 2016 рік «Дані міст України: open data in progress». 2016. URL: http://uacrisis.org/ua/51882-opendata

8. Инглхарт Р., Вельцель К. Модернизация, культурные изменения и демократия. Последовательность человеческого развития. М.: Новое издательство. 2011.464 с.

9. Індекс сприйняття корупції. Transparency International Ukraine. URL: https://ti-ukraine.org/research/indeks-koruptsiyi-cpi-2016/

10. Конституція України : станом на 1 верес. 2016 р. / Верховна Рада України. Харків : Право, 2016. 82 с.

11. Корж К.М. Концептуалізація соціального контролю як технологічного засобу стримування соціальних відхилень соціологічних теоріях кінця XIX - початку XX століття/ К. М. Корж. Актуальні проблеми сочіології, психології, педагогіки. 2011. Вип. 13. С. 32-41.

12. Коэн Д., Арато Э. Гражданское общество и политическая теория / пер. с англ. Мюрберг И. И. и др.. Москва : Весь мир, 2003. 782 с.

13. Кравчук В. Полісуб'єктність громадського контролю у механізмі державного управління/ В. Кравчук. National law journal: theory and practice. 2016. № 5 (21). C. 11-15.

14. Національна стратегія сприяння розвитку громадянського суспільства в Україні на 2016 - 2020 рр., затверджена Указом Президента України № 68/2016 від 26.02.2016 p. URL: http://www.president.gov.ua/ documents/682016-19805.

15. Політична думка XX - початку XXI століть: методологічний та доктринальний підходи: у 2-х т./ за заг. ред. Н.М. Хоми. Львів: Новий Світ-2000, 2016. Т. 1. 516 с.

16. Поппер К. Відкрите суспільство та його вороги / пер. 3 анг. О. Коваленко: в 2 т. К. : Основи, 1994. Т. 1. 444 с.

17. Поцелуйко А. О. Образ держави в соціальному конструктивізмі та структурному функціоналізмі / А. О. Поцелуйко. Грані. 2015. № 7. C. $34-40$.

18. Практика використання інструментів електронної демократії громадськими організаціями в Україні. Результати експертного опитування. ГО «Подільська агенція регіонального розвитку». 2016. 49 с.

19. Про забезпечення участі громадськості у формуванні та реалізації державної політики : постанова Кабінету Міністрів України від 03.11.2010. № 996. Урядовий кур’єр. 2010. № 84. 
20. Про засади запобігання і протидії корупції : Закон України від 07.04.2011 № 3206-VI. Голос Украӥни. 2011. № 107.

21. Про затвердження Порядку сприяння проведенню громадської експертизи діяльності органів виконавчої влади: Постанова Кабінету Міністрів України від 5 листопада 2008 р. № 976. Офіційний вісник України. 2008. № 86. Ст. 100.

22. Проект Закону України «Про громадський контроль» від 13.05.2015. № 2737-1 URL: http://w1.c1.rada.gov.ua/pls/zweb2/webproc4_1? pf3511=55101

23. Проект Закону України «Про громадський контроль» від 14.04.2014 № 4697. URL: http://w1.c1.rada.gov.ua/pls/zweb2/webproc4_2? pf3516 $=4697 \&$ skl $=8$

24. Проект Закону України «Про громадянський контроль за діяльністю органів влади, їх посадових і службових осіб» від 07.08.2018 № 9013. URL: http://w1.c1.rada.gov.ua/pls/zweb2/webproc4_1?pf3511=64506

25. Пухкал О. Г. Громадський контроль як важливий чинник демократизації та ефективності державного управління / О. Г. Пухкал. Інвестииії: практика та досвід. 2010. № 14. С. 56-58.

26. Середа Т. Стратегічні орієнтири взаємодії органів державного управління з громадськістю у процесі реалізації конституційно-правової реформи / Т. М. Середа. Теорія та практика державного управління. 2018. Вип. 2. С. 81.

27. Стрілець Ю. П. Види і форми контролю в місцевому самоврядуванні / Ю. П. Стрілець. Теорія та практика державного управління. 2011. Вип. 3. С. 353-359.

28. Стрілець Ю. Принцип підконтрольності в контексті концепції "good governance" /Ю. П. Стрілець Актуальні проблеми державного управління. 2011. № 2. С. 319-325.

29. Туровский Р. Национализация и регионализация партийных систем: подходы к исследованию / Р. Туровский.Полития. 2016. № 1. C. $162-180$.

30. Arnstein Sh. R. A Ladder of Citizen Participation, Journal of the American Institute of Planners, 35 (4). (July 1969), pp. 216-224.

31. Fukuyama F. What is Corruption? Against Corruption: a collection of essays : websites. URL: https://www.gov.uk/government/publications/ against-corruption-a-collection-of-essays/against-corruption-a-collection-ofessays

32. Kermach R., Sukharyna A. Independent think tanks and government: is there any progress in bilateral cooperation?. Analytical report. URL:http://dif.org.ua/uploads/pdf/36483373158dd0b040e0aa2.11421606.pdf 
33. Pettit P. 2008, Three Conceptions of Democratic Control / P. Pettit. An International Journal of Critical and Democratic Theory, 2008. Vol. 15, No. 1, pp. 46-55.

34. Public Participation in Europe: An International Perspective" (EIPP, 2009) URL: http://www.partizipation.at/fileadmin/media_data/Downloads/ Zukunftsdiskurse-Studien/pp_in_e_report_03_06.pdf

35. Report of Ukraine. Freedom in the World. 2017. URL: https://freedomhouse.org/report/freedom-world/2017/ukraine

36. Ukraine: Handbook on Transparency and Citizen Participation. Partnership for Good Governance. Council of Europe. 2017a URL: https://rm.coe.int/handbook-ukraine-eng/168078406c

Information about the author:

Holubiak N. R.,

Candidate of Political Sciences (Ph.D),

Postdoctoral researcher,

Vasyl Stefanyk Precarpathian National University

57, Shevchenko str., Ivano-Frankivsk, 76000, Ukraine 


\section{CURRENT STATUS AND ANALYSIS OF CHINA'S REGIONAL AND BILATERAL TRADE AGREEMENTS}

\section{Korol M. M.}

\section{INTRODUCTION}

The strategic partnership as a type of bilateral relations has a deep character, which is not limited only by the foreign trade relations, but has certain systemic features and demonstrates a dynamic development both on quantitative and institutional level with the general aim to harmonize the bilateral economic development. As said above, the regional economic integration must take place at the initial stages of strategic partnership between countries. The secondary objective of strategic partnerships is to ensure the structural and balanced economic development of partner countries. From the point of view of internationalization, the definition of strategic partnership is considered as a level of cooperation between countries, within which the common goals are achieved and common interests are agreed. At the regional level of the systemic hierarchy, strategic partnership is considered as the collaboration between companies and organizations, that share common goals and strive to achieve them ${ }^{1}$.

In the further research, we consider it advisable to focus on the strategic cooperation in the spheres of economy and trade. One of the key events in China's foreign trade policy was joining an international organization such as World Trade Organization (WTO) on December 11, 2001, which, however, was preceded by a lengthy negotiation process. In particular, the WTO has required significant changes in the Chinese economy.

According to the WTO Dispute Settlement System, from January 1, 2016 to March 31, 2018, China was involved in six cases as a respondent and two as a complainant.

After accession to the WTO China has begun to work more actively on regional and bilateral trade agreements.

Authorities say the strategy is to accelerate the implementation of free trade agreements (FTA) is an important element of the new round of trade liberalization in China.

${ }^{1}$ Висоцька М. Аналіз основних тенденцій розвитку економічних відносин між Україною та Китаєм / М. Висоцька, А. Аль Атті // Стратегія розвитку України. Економіка, соціологія, право. - 2013. - № 4. - С. 14-20, с. 14. 
During 2001-2018, China signed 18 free trade agreements (3 of which were revised and upgraded) with 24 countries or regions (Table 1): Maldives; Georgia; Australia; Republic of Korea; Switzerland; Iceland; Costa Rica; Peru; Singapore; New Zealand; Chile; Pakistan; ASEAN; Hong Kong, China; Macau, China; ASEAN (upgraded); Chile (upgraded); Singapore (upgraded).

Table 1

Free Trade Agreements and Contract Dates ${ }^{2}$

\begin{tabular}{|c|c|}
\hline \multicolumn{2}{|c|}{ Free Trade Agreements } \\
\hline Subjects & Contract Date \\
\hline Maldives & December 2017 \\
\hline Georgia & May 2017 \\
\hline Australia & December 2015 \\
\hline Republic of Korea & June 2015 \\
\hline Switzerland & July 2013 \\
\hline Iceland & April 2013 \\
\hline Costa Rica & April 2010 \\
\hline Peru & April 2009 \\
\hline Singapore & October 2008 \\
\hline New Zealand & April 2008 \\
\hline Chile & November 2005 \\
\hline Pakistan & November 2006 \\
\hline ASEAN & November 2004 \\
\hline Hong Kong, China (CERA) & June 2003 \\
\hline Macau, China & October 2003 \\
\hline ASEAN (upgraded) & November 2015 \\
\hline Chile (upgraded) & November 2017 \\
\hline Singapore (upgraded) & November 2018 \\
\hline
\end{tabular}

Analyzing the table 1 it is worth noting that after 2013, China has stepped up its activity in contracting or updating its free trade agreements. The main

${ }^{2}$ China's Free Trade Agreements [Електронний pecypc]. - 2019. - Режим доступу до pecypcy: http://fta.mofcom.gov.cn/english/fta_qianshu.shtml] 
reason, in our view, is the Global Chinese Initiative "Belt and Road Initiative" (which began its operation in 2013), which was expected to strengthen relations with as many countries as possible, which will be discussed later.

15 Free Trade Agreements are under discussion (Table 2): Comprehensive Regional Economic Partnership; Gulf Cooperation Council; Japan-South Korea; Sri Lanka; Israel; Norway; Pakistan (at the 2nd stage); New Zealand (upgraded); Mauritius; Moldova; Panama; Republic of Korea (at the 2nd stage); Palestine; Peru (upgraded).

Table 2

Free Trade Agreements (Under Discussion) and Discussion Start Date ${ }^{3}$

\begin{tabular}{|c|c|}
\hline \multicolumn{2}{|c|}{ Free Trade Agreements (under discussion) } \\
\hline Subjects & Discussion Start Date \\
\hline Comprehensive regional economic partnership & May 2013 \\
\hline Gulf Cooperation Council & July 2004 \\
\hline Japan-South Korea & August 2013 \\
\hline Sri Lanka & August 2013 \\
\hline Israel & March 2016 \\
\hline Norway & September 2008 \\
\hline Pakistan (Stage 2) & December 2016 \\
\hline New Zealand (upgraded) & November 2016 \\
\hline Mauritius & November 2016 \\
\hline Moldova & May 2017 \\
\hline Panama & November 2017 \\
\hline Republic of Korea (at the 2nd stage) & December 2017 \\
\hline Palestine & July 2018 \\
\hline Peru (upgraded) & November 2016 \\
\hline
\end{tabular}

From the table 2, it is clear that after 2013, the number of free trade agreements under discussion has been also increasing.

A certain preferential trade agreement was signed in 1975, known as "Asia-Pacific Trade Agreement". This initiative of the United Nations Economic and Social Commission for Asia and the Pacific is a preferential trade agreement among developing countries. Since September 1, 2006, the results of the third round of tariff reduction negotiations have been successfully implemented by all members of APTA ${ }^{4}$.

${ }^{3}$ Free Trade Agreements under Negotiation [Електронний ресурс]. - 2019. - Режим доступу до ресурсу: http://fta.mofcom.gov.cn/english/fta_tanpan.shtml

${ }^{4}$ Asia-Pacific Trade Agreement [Електронний pecypc]. - 2018. - Режим доступу до pecypcy: http://fta.mofcom.gov.cn/topic/enpacific.shtml. 
On September 12-14, 2018, the 53rd meeting of the Standing Committee of the Asia-Pacific Trade Agreement and related meetings were held in Seoul (South Korea) to discuss issues such as trade in services, investment, trade facilitation rules. It should be noted that this is the first meeting of the Standing Committee after the implementation of the 4th round of tariff concession negotiations, which took place on July $1,2018 .^{5}$

During 2018-early 2019, China also worked in the following areas:

\section{Free Trade Agreement with Georgia}

The Free Trade Agreement between the Government of the People's Republic of China and the Government of Georgia came into force on January 1, 2018 and it is the first free trade agreement that China has signed with Eurasian countries.

After the agreement had come into force, Georgia imposed zero tariffs on $96.5 \%$ of China's products, and China imposed a zero tariff on $93.9 \%$ of Georgian products, $90.9 \%$ of which had zero tariffs at once and the remaining $3 \%$ would gradually to decrease to zero for the next 5 years ${ }^{6}$.

From January 1, 2018, Georgian wine, mineral water, honey, tea, fruits, vegetables and agricultural products will be exported to China at zero tariffs. By taking the opportunity to reach this agreement, China and Georgia will comprehensively improve the level of practical cooperation between them, thus promoting the common prosperity ${ }^{7}$.

As a result, in 2018, China imported \$ 53.6 million of Georgian wine and took the 3rd place in the import of grapes in Georgia. Last year, 7,585,407 bottles of Georgian wine were exported to China, which is of $43 \%$ more, compared to $2016^{8}$.

\section{Free Trade Agreement with the Republic of Korea}

On March 22, 2018, the 2nd meeting of the Committee on Free Trade between China and the Republic of Korea took place. Both sides appreciated the positive role of FTAs in facilitating bilateral trade and investments and exchanged views on the implementation of FTAs. They decided that they would

${ }^{5}$ The 53rd Asia-Pacific Trade Agreement Standing Committee Meeting and Related Panel Meetings Held in South Korea [Електронний pecypc]. - 2018. - Режим доступу до ресурсу: http://fta.mofcom.gov.cn/enarticle/enpacific/enasiapacificnews/201809/38904_1.html.

${ }^{6}$ China-Georgia FTA Comes into Force Today [Електронний ресурс]. - 2018. - Режим доступу до ресурсу: http://fta.mofcom.gov.cn/enarticle/chinageorgiaen/chinageorgiaennews/ 201801/36885_1.html.

${ }^{7}$ Georgia-China free trade deal comes into play from January 2018 [Електронний pecypc]. - 2018. - Режим доступу до ресурсу: http://agenda.ge/en/news/2018/29

${ }^{8}$ China ranks 3rd for Georgia's wine exports in 2018 [Електронний ресурс]. - 2019. Режим доступу до ресурсу: http://www.xinhuanet.com/english/2019-01/05/c_137720361.htm. 
go the way of leaders and negotiate the specific technical problems, with the further implementation of preferential measures and better benefits for the two countries and their people.

The first tariff cut was officially announced on December 20, 2015. Since then, the two sides have cut tariffs four times and zero-tariff products have covered $50 \%$ of bilateral trade ${ }^{9}$

In 2018, China ranks the 1st place in South Korea's exports and is worth \$ 162.2 billion. The United States (26.8\% of South Korea's total exports). During the same year, South Korea experienced the highest trade surpluses within three countries, including China $(25.8 \%)^{10}$.

\section{Free Trade Agreement with Iceland}

September 18-19, 2018 The 3rd Joint Committee on Free Trade between China and Iceland took place in Iceland. At the meeting, both sides praised the achievements of the Free Trade Agreement. They agreed that the implementation of their free trade agreement was widespread for the people and businesses of the two countries and deepened bilateral economic ties.

They also agreed to further FTA cooperation, encourage enterprises to fully implement the FTA preferential policy, and facilitate the development of bilateral economic and trade cooperation to strengthen economic and trade relations between China and Iceland and trade relations between China and European countries ${ }^{11}$.

In 2018, the Iceland's exports to China are totaled \$ 144.3 million or $2.6 \%$ of its total exports ${ }^{12}$.

\section{Free Trade Agreement with New Zealand}

On September 10-13, 2018, the 5th round of free trade zone negotiations with China and New Zealand took place in Beijing. Both sides consulted extensively on issues relating to technical barriers of trade, rules of passage, trade in services, e-commerce, the environment and public procurement. A new FTA negotiation process between China and New Zealand was officially launched in November 2016. The renovation of the FTA will further promote

${ }^{9}$ The 2nd Joint Commission on China-ROK FTA Held in Seoul [Електронний ресурс]. 2018. - Режим доступу до ресурсу: http://fta.mofcom.gov.cn/enarticle/enkorea/enkoreanews/ 201808/38460_1.html.

${ }^{10}$ South Korea's Top Trading Partners [Електронний ресурс]. - 2019. - Режим доступу до ресурсу: http://www.worldstopexports.com/south-koreas-top-import-partners/.

${ }_{11}$ The 3rd Meeting of Joint Committee of China-Iceland FTA Held in Iceland [Електронний ресурс]. - 2018. - Режим доступу до ресурсу: http://fta.mofcom.gov.cn/enarticle/ eniceland/enicelandnews/201809/38980_1.html

12 Top Iceland Exports [Електронний ресурс]. - 2019. - Режим доступу до ресурсу: http://www.worldsrichestcountries.com/top-iceland-exports.html 
economic and trade relations between China and New Zealand, as well as, enhance bilateral economic and trade cooperation. ${ }^{13}$

New Zealand's exports to China have risen since the first Free Trade Agreement (2008) was signed. In 2018, tariffs have been eliminated for more than $97 \%$ of New Zealand's exports to China.

Currently, China is New Zealand's largest trading partner with bilateral trade worth over $\$ 27$ billion $^{14}$.

\section{Free Trade Agreement with ASEAN (upgraded)}

On March 11-15, 2018, the 11th Joint Commission on the updating of the FTA between China and the ASEAN countries took place in Beijing.

At the meeting, both sides praised the FTA of China and ASEAN for its positive impact on people and business, especially since the progress of the implementation of the updated Free Trade Agreement between China and ASEAN. Negotiations were also held on the exchange of experience and practice in the field of trade and e-commerce promotion.

Both sides agreed to strengthen the FTA cooperation, take full advantage of preferential policies and raise bilateral trade and economic cooperation into a new level.

China has been ASEAN's leading trading partner for 10 years, and ASEAN is China's third largest trading partner, after the European Union and the US for eight years. Implementation of the Free Trade Agreement is the basis for consolidating and developing a strategic partnership between China and ASEAN $^{15}$.

In 2018, bilateral trade between China and ASEAN increased by $14.1 \%$ to a record $\$ 587.87$ billion. A number of key factors, which have contributed to the strengthening of economic relations between China and ASEAN. Among the main are the following:

1) a rapid economic growth in both ASEAN and China;

2) the creation of a Free Trade Area between China and ASEAN, which has substantially removed the tariff barriers in goods trade between China and ASAN since 2010;

${ }^{13}$ The 5th Round of Upgrading Negotiation of China-New Zealand Free Trade Agreement Held in Beijing [Електронний pecypc]. - 2018. - Режим доступу до ресурсу: http://fta.mofcom.gov.cn/enarticle/ennewzealand/ennewzealandnews/201809/38897_1.html

${ }^{14}$ New Zealand-China FTA overview [Електронний ресурс]. - 2018. - Режим доступу до ресурсу: https://www.mfat.govt.nz/en/trade/free-trade-agreements/free-trade-agreements-inforce/china-fta/nz-china-fta-overview/.

${ }^{15}$ The 11th Joint Commission on China-ASEAN FTA Held in Beijing [Електронний pecypc]. - 2018. - Режим доступу до ресурсу: http://fta.mofcom.gov.cn/enarticle/enasean/ chianaseannews/201803/37518_1.html. 
3) the consumer markets of both China and ASEAN have grown rapidly over the last decade, driving the demand for a wide range of imported goods and services. Analyzing the investment sector, there are also positive results: by the end of 2018, China has invested \$ 89.01 billion to ASEAN, and ASEAN invested \$ 116.7 billion to China, which has increased bilateral investment for 22 times in 15 years, especially as China's investments to ASEAN began to flow faster. ${ }^{16}$

In 2018, Indonesia's trade with China grew most rapidly from the 10 ASEAN member countries by $22.2 \%$ to $\$ 77.4$ billion. In particular, sales in China from Indonesian imports rose to $19.6 \%$, which is the second largest indicator of sales of China's imports. In 2018, China and ASEAN commemorated the 15th anniversary of the Strategic Partnership, and in November 2018, at the 21st China-ASEAN Summit, both sides announced the 2030 China-ASEAN Strategic Partnership, setting out medium- and long-term plans for the future cooperation.

ASEAN is a key focus for Belt and Road construction, and it was in Indonesia where the Chinese President proposed an important initiative to create the 21st Century Silk Road in 2013. ${ }^{17}$

The above data and facts indicate that China and ASEAN are not only good neighbours but good friends. China is also one of ASEAN's most important trading and investment partners, and vice versa. Trade relations between China and ASEAN are in a complete harmony.

\section{Free Trade Agreement with Chile (upgraded)}

On March 1, 2019, the updated Free Trade Agreement between the Government of the People's Republic of China and the Government of the Republic of Chile entered into force. China has gradually phased out some tariffs on wood products over three years, and Chile has abolished tariffs on textiles, clothing, household appliances and sugar. Products that both sides will sell at zero tariff, will reach $98 \%$. The China-Chile Free Trade Area will become China's FTA with the highest level of open trade.

In terms of trade in services, both sides will expand and increase the number and level of service trade commitments. China will continue to expand in more than 20 sectors, including commercial legal services, entertainment and distribution. Chile has pledged to open up higher levels in more than 40 sectors, including express delivery, transportation and construction. In addition, the

${ }^{16}$ ASEAN-China trade boosting growth [Електронний ресурс]. - 2018. - Режим доступу до ресурсу: http://global.chinadaily.com.cn/a/201811/19/WS5bf1f6a6a310eff303289619.html

${ }^{17}$ China and ASEAN doing well on economic, trade cooperation [Електронний ресурс]. 2019. - Режим доступу до ресурсу: https://www.thejakartapost.com/academia/2019/01/31/chinaand-asean-doing-well-on-economic-trade-cooperation.html 
Protocol has also been revised and supplemented by sections including rules of origin, economic and technical cooperation, as well as, new rules on e-commerce, competition, environment and trade ${ }^{18}$.

In 2018, the bilateral trade between China and Chile reached $\$ 42.8$ billion, which is $24 \%$ more than the previous year. This accounts for almost a third of Chile's total foreign trade ${ }^{19}$.

\section{Free Trade Agreement with Singapore (upgraded).}

On November 5, 2018, a meeting between China and Singapore took place at the first largest exhibition of imported goods and services, "China International Import Expo", where they jointly announced the completion of negotiations to update the existing Free Trade Agreement between China and Singapore. Both parties will sign the protocoll of the Government of the PRC and the Government of the Republic of Singapore after the completion of the demanding internal procedures ${ }^{20}$.

In 2018, Singapore's exports to China totaled $\$ 50.4$ billion or $12.2 \%$ of its total exports. However, in February 2019, Singapore's exports declined by $8.5 \%$ compared to last year due to the decline in electronic and non-electronic traffic, in turn, due to the China-US trade war. This was its worst performance since October 2016, when it was down by $12 \%$.

Overall, in 2019, China announced that it will start reducing or lowering import tariffs for 706 products starting from January 1, with the aim of reducing consumer's spending.

While the first two rounds of tariff cuts in China were mainly focused on consumer's goods and manufactured goods, the last round affects a wide range of commodities such as cotton, fur, some pharmaceutical raw materials, and will continue to temporarily reduce tariffs on products such as aircraft engines, welding jobs and natural resources.

In addition, China will introduce lower ordinary tariffs in accordance with previously agreed trade agreements with 23 countries and territories,

${ }^{18}$ The Protocol Upgrading China-Chile Free Trade Agreement Comes into Force Today [Електронний ресурс]. - 2019. - Режим доступу до ресурсу: http://fta.mofcom.gov.cn/ enarticle/enchile/enchilenews/201903/39927_1.html

${ }^{19}$ China-Chile FTA Upgraded, New Opportunities for Investors [Електронний ресурс]. 2019. - Режим доступу до ресурсу: https://www.china-briefing.com/news/china-chile-ftaupgraded-market-opportunities-investors/

${ }^{20}$ China and Singapore Sign Protocol to Upgrade the Free Trade Agreement [Електронний pecypc]. - 2018. - Режим доступу до ресурсу: http://fta.mofcom.gov.cn/enarticle/singaporetwoen/ singaporetwoennews/201811/39360_1.html

${ }^{21}$ Biggest fall in Singapore exports in over two years [Електронний ресурс]. - 2019. Режим доступу до ресурсу: https:/www.straitstimes.com/business/economy/biggest-fall-in-sporeexports-in-over-two-years 
including: New Zealand, Peru, Costa Rica, Switzerland, Iceland, South Korea, Australia and Georgia ${ }^{22}$.

Let us analyze in more detail the concept of the "Belt and Road Initiative" as China's strategically important global economic project.

The concept of the "Belt and Road Initiative" is a strategic project initiated in 2013 by the President of China Xi Jinping during his visits to Kazakhstan and Indonesia with the purpose of restoring ancient trade routes (previously extending across Asia and Europe). According to this document, it is a network of roads, railways, oil pipelines, power grids, ports and other infrastructure projects designed to connect China to world trade ${ }^{23}$.

The BRI is comprised of two related projects (Figure 1) and covers almost 65 countries, with $63 \%$ of the planet's population, with an estimated economic scale of US \$ 21 trillion.

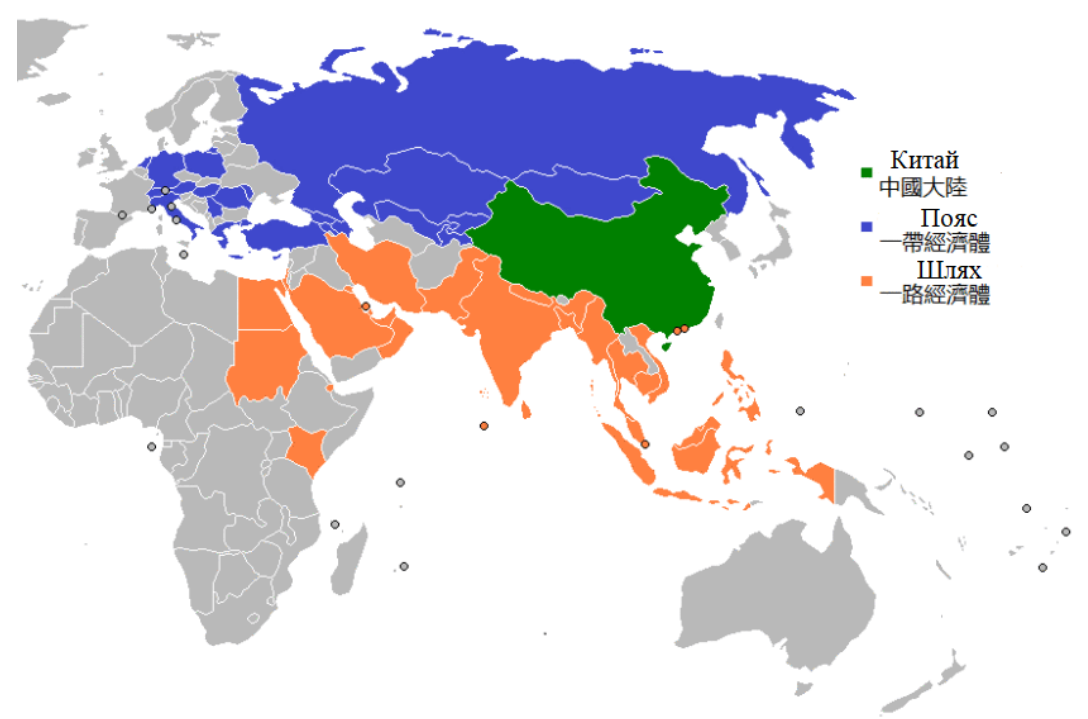

Fig. 1. Global Chinese "Belt and Road Initiative" 24

${ }^{22}$ New Tariff, Export Duty Cuts in China for 2019 [Електронний ресурс]. - 2019. Режим доступу до ресурсу: https://www.china-briefing.com/news/new-tariff-export-duty-cutschina-2019-wide-variety-products-affected/

${ }^{23}$ What is One Belt, One Road in China? [Електронний ресурс]. - 2017. - Режим доступу до ресурсу: https://www.quora.com/What-is-One-Belt-One-Road-in-China

${ }_{24}$ Один пояс, один шлях [Електронний ресурс]. - 2018. - Режим доступу до ресурсу: http://agora-web.jp/archives/2035163.html 
China is highlighted in green, the territory where Belt Initiative is implemented - blue, and the Road is orange. Let's analyze in more detail the picture above.

1. The Belt, also known as the Silk Road Economic Belt, is the creation of three trans-Eurasian economic corridors: the North (China - Central Asia Russia - Europe), the Central (China - Central and West Asia - the Persian Gulf and the Mediterranean). sea) and the south (China - Southeast AsiaSouth Asia - Indian Ocean). It is also a network of land road and rail routes, oil and gas pipelines, as well as other infrastructure projects that will go from Xi'an in central China through Central Asia and to Rotterdam and Venice.

2. The Road, also known as the 21st Century Silk Road, is the creation of two maritime routes: one route from China's coast through the South China Sea to the South Pacific, the other involves the connection of coastal regions of China and Europe across the South China Sea and the Indian Ocean.

It is also a network of ports and other infrastructure projects in the coastal regions of South and Southeast Asia, East Africa and the Northern Mediterranean. Infrastructure projects can play a constructive role in the regional economic architecture and help strengthen political institutions in the region, which will generally reduce incentives and opportunities for terrorist movements.

Also, the elements of this initiative $\operatorname{are}^{25}$ :

3. China-Pakistan Economic Corridor.

4. China-Bangladesh-India-Myanmar Economic Corridor.

The reasons for the creation of the "Belt and Road Initiative" for China include:

1) China's intention to develop its international influence, since despite its economic strength, it is not a member of the G7 countries. In this way, the BRI will allow China to have greater regional influence;

2) China's GDP has slowed down in recent years, even though its development is faster than in other countries. This initiative will serve as another significant impetus for its growth and will open new markets for Chinese products;

3) China's growth model was mainly investment, which in turn led to excess capacity. This excess capacity will be effectively allocated if China enters new markets;

4) China intended to make the yuan an international reserve currency;

5) China's eastern and southern regions are lagging in their development, and the BRI will allow them to correct these regional differences. Regions will have better connection with the world ${ }^{26}$.

${ }^{25}$ Один пояс, один шлях [Електронний ресурс]. - 2017. - Режим доступу до ресурсу: http://sinologist.com.ua/odin-poyas-odin-shlyah-globalnij-geoekonomichnij-proekt-kitayu]: 
"The Silk Road Economic Belt" and "the 21st Century Silk Road" occupy an important place in China's 13th Five Year Plan (2016-2020) and will be determined by the national investment strategy over the period ${ }^{27}$.

In his speech in 2013, the President of the People's Republic of China outlined 5 principles through which joint projects within the "Belt and Road Initiative" can be implemented:

1. Increased political consultation between countries. The Chairman of the People's Republic of China proposed a regular exchange of views on the strategy and tactics of economic development. Guided by the principle of achieving unity of opinion while maintaining differences and through consultations, develop programs and measures for the development of regional cooperation, regional economic integration in political and legal terms.

2. Strengthening the construction of a single transport network. The Chairman of the People's Republic of China also stated China's readiness to consider actively improving cross-border transport infrastructure with all countries in favor of the gradual establishment of a network connecting eastern, western and southern Asia. This will create favorable conditions for economic development and travel for citizens of the countries of the region.

3. Strengthening trade links. The Silk Road economic strip is home to about 3 billion people, and there are huge markets, meaning trade and investment cooperation has great potential. It is advisable to look for adequate trade and investment facilitation schemes, work on elimination of trade barriers, reducing unnecessary trade and investment costs, and increasing the speed and quality of economic transactions.

4. Increase in payments in national currencies. China suggested active switch to national currency payments. The transition to national currencies in exchanges and settlements in current and capital operations will significantly reduce the cost of money transactions, strengthen the economies of countries, prevent financial risks and increase the international competitiveness of the regional economy.

5. Strengthening people-level connections. Interstate relations are based on mutual friendship between peoples, and in order to succeed in cooperation in the above-mentioned areas, it is imperative to have popular support, to strengthen friendly contacts between peoples, to strengthen mutual understanding and traditional friendship. In this way, regional cooperation will gain a strong social and public base.

${ }^{26}$ What is One Belt, One Road in China? [Електронний ресурс]. - 2017. - Режим доступу до ресурсу: https://www.quora.com/What-is-One-Belt-One-Road-in-China

${ }^{27}$ Один пояс, один шлях [Електронний ресурс]. - 2017. - Режим доступу до ресурсу: http://sinologist.com.ua/odin-poyas-odin-shlyah-globalnij-geoekonomichnij-proekt-kitayu/ 
Official documents published by the Ministry of Foreign Affairs of the PRC and the Ministry of Commerce of the PRC emphasize that the "Belt and Road Initiative" goes far beyond the construction of infrastructure. The project will include not only the expansion of cross-border trade and investment, financial integration, but also the internationalization of the yuan, the establishment of links between regional ICT networks and the like ${ }^{28}$. It is noted that the BRI does not contain the idea of creating a free trade area and does not provide for binding agreements between states. Instead, China's intentions to use its economic resources and diplomatic tools are at its core. The use of less formal mechanisms will give the project flexibility and allow Beijing to maximize its economic and political potential.

The BRI project is not so much the result of negotiations, but the result of coordination through consultation, which is a new model of cooperation development. The Chinese government, assessing domestic and international factors in the light of time and circumstances, has proposed a new type of openness strategy, which consists of two important components "complementarity and overall benefit" and "geopolitical considerations" 29.

Many countries in Europe and Asia are interested in it because one of the main obstacles to their economic growth is the underdeveloped transport system.

Under the terms of project financing, China has planned to spend about \$ 1 trillion in investment in various infrastructure projects, while providing loans to low-cost countries through a flexible financing system consisting of the following institutions:

1. The Silk Road Fund (established in 2014, and received US $\$ 40$ billion in funding the same year).

2. Chinese Development Bank.

3. Import and Export Bank of China.

4. New Development Bank (located in Shanghai with registered capital of US $\$ 50$ billion).

5. Asian Investment Infrastructure Bank with 57 founding members (established in 2015 with registered capital of US $\$ 100$ billion) ${ }^{30}$.

Despite Washington's opposition, American allies, including Australia, the United Kingdom, Germany, Italy, the Philippines and South Korea, have

${ }^{28}$ Пятилетнее путешествие Пояса и Пути [Електронний ресурс]. - 2018. - Режим доступу до ресурсу: https://nv.ua/ukr/world/countries/pjatirichna-podorozh-pojasom-i-shljakhom2496956.html

${ }^{29}$ Один пояс, один шлях [Електронний ресурс]. - 2017. - Режим доступу до ресурсу: http://sinologist.com.ua/odin-poyas-odin-shlyah-globalnij-geoekonomichnij-proekt-kitayu/

30 Китайський проект «Один пояс, один шлях» та його можливості для України [Електронний ресурс]. - 2018. - Режим доступу до ресурсу: https:/hvylya.net/analytics/ economics/kitayskiy-proekt-odin-poyas-odin-shlyah-ta-yogo-mozhlivosti-dlya-ukrayini.html 
joined the AIIB, which clearly represents a huge political success for China. Obviously, Beijing's AIIB will give China more independence from the US financial system ${ }^{31}$.

The AIIB budget is in line with Marshall's plan for Europe after the end of World War II. However, this project is not based on a Western model, when leading countries form and manage multilateral institutions, which is underpinned by treaties, international law, and sovereignty. Beijing offers economic opportunities at the level of bilateral relations and regional summits, demonstrating not only the economic recovery of the country, but also the national revival or renewal of the Chinese nation ${ }^{32}$.

Since the beginning of this initiative, the Chinese government has invested over US $\$ 130$ billion abroad (essentially to other countries) ${ }^{33}$.

In May 2017, Beijing hosted the first The Belt and Road International Cooperation Forum, delegations from 100 countries were invited, 29 of which were led by top officials. The purpose of the forum was to coordinate a number of projects that are already being implemented or will be implemented within the initiative. The final communiqué lists 270 of them. Although projects are at different stages of implementation, and some of them even face difficulties due to competition and opposition, it is now possible to say that the Belt and Road initiative already has a clear practical outcome ${ }^{34}$.

The successful implementation of this initiative in the medium and long term should contribute to deepening regional economic integration, expanding cross-border trade and financial flows between Eurasian countries and the outside world, as well as further strengthening the Chinese-oriented trading model, investments and infrastructure. Increasing of energy and mineral resources investment, especially in Central Asia, will help reduce China's dependence on imported commodities from abroad, including oil supplied through the Strait of Malacca ${ }^{35}$.

${ }^{31}$ One Belt - One Road [Електронний ресурс]. - 2017. - Режим доступу до ресурсу: http://www.textilevaluechain.com/index.php/article/industry-general/item/1272-one-belt-one-roadchina-s-big-initiative-creating-massive-business-opportunities-sourced-compiled-by-arvind-sinha

${ }^{32}$ Один пояс, один шлях [Електронний ресурс]. - 2017. - Режим доступу до ресурсу: http://sinologist.com.ua/odin-poyas-odin-shlyah-globalnij-geoekonomichnij-proekt-kitayu/

33 Китайський проект «Один пояс, один шлях» та його можливості для України [Електронний ресурс]. - 2018. - Режим доступу до pecypcy: https://hvylya.net/analytics/ economics/kitayskiy-proekt-odin-poyas-odin-shlyah-ta-yogo-mozhlivosti-dlya-ukrayini.html.

${ }^{34}$ Пятилетнее путешествие Пояса и Пути [Електронний ресурс]. - 2018. - Режим доступу до ресурсу: https://nv.ua/ukr/world/countries/pjatirichna-podorozh-pojasom-i-shljakhom2496956.html]

${ }^{35}$ Один пояс, один шлях [Електронний ресурс]. - 2017. - Режим доступу до ресурсу: http://sinologist.com.ua/odin-poyas-odin-shlyah-globalnij-geoekonomichnij-proekt-kitayu/ 
One of China's goals has already been achieved. As of 2016, the Chinese currency (yuan) has officially entered the list of international reserve currencies, and its impact as of 2018 is estimated at the Eurocurrency level ${ }^{36}$.

The Sino-Pakistan Economic Corridor, which consists of several infrastructure projects in Pakistan worth USD 62 billion, is the most global of the projects implemented.

The main objective is to open a new trade route from the Middle Kingdom (Kashgar) to the Pakistani port of Gwadar (exit to the Arabian Sea).

In 2016, the first batch of Chinese goods was already shipped from Gwadar to Africa. The investment helped modernize Pakistan's existing transportation infrastructure and revitalized the economy, as can be seen in Fig. 3 .

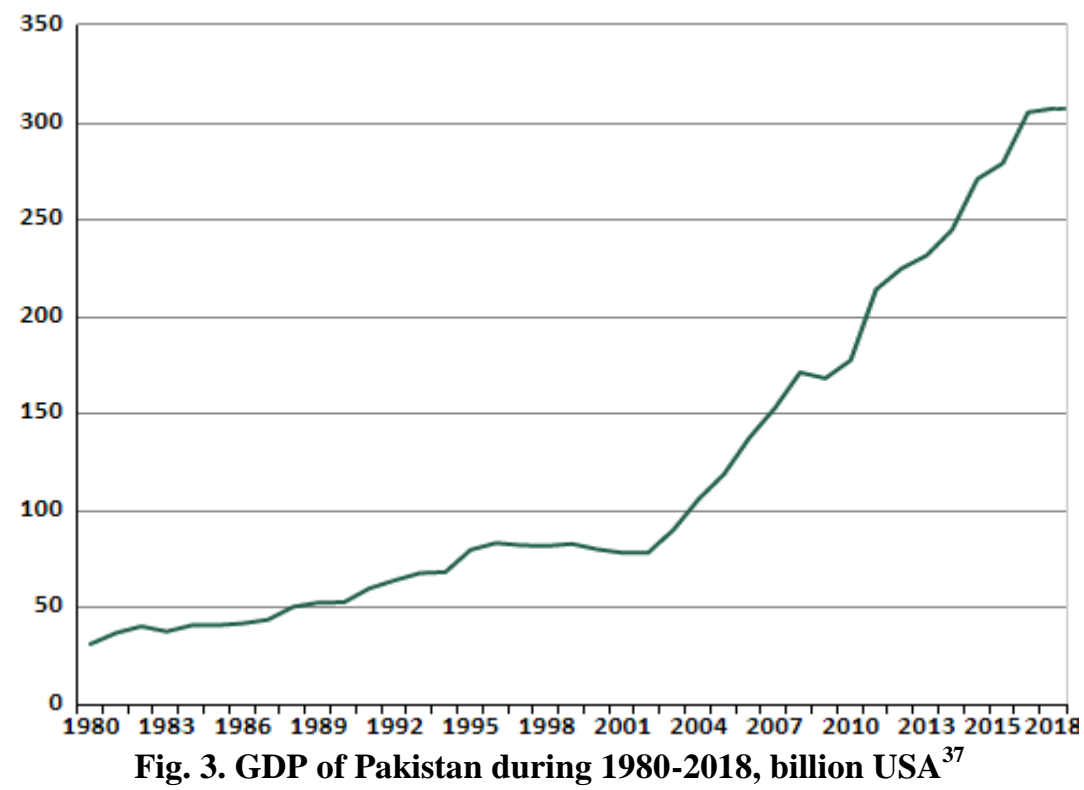

Pakistan's GDP grew from USD 278.66 billion in 2016 to USD 306.9 billion in 2018 .

${ }^{36}$ Евро и юань могут потеснить доллар в глобальной торговле [Електронний ресурс]. 2018. - Режим доступу до ресурсу: https://finance.liga.net/ekonomika/novosti/v-perspektive-dollarmojet-poteryat-mirovoe-gospodstvo---prognoz; Юань став резервною валютою і потіснив євро [Електронний ресурс]. - 2016. - Режим доступу до ресурсу: https://www.dw.com/uk/юань-ставрезервною-валютою-і-потіснив-євро/а-35931655

${ }^{37}$ Пакистан - Валовой внутренний продукт [Електронний ресурс]. - 2019. - Режим доступ до ресурсу: https://knoema.ru/atlas/Пакистан/ВВП 
According to the Pakistani government, this project is expected to create 700,000 working paces for over 10 years and add $2.5 \%$ annually to economic growth by 2030 .

Several projects of less global importance have also been implemented: construction of a power plant in Bangladesh (USD 165 million), replacement of Indonesian slums with modern housing (USD 216.5 million), construction of a hydroelectric power plant in Oman (USD 301 million) ${ }^{38}$.

China and its partner countries have staked on the development of the rail connection between East and West of Eurasia. As of August 26, 2018 the total number of trains from China to Europe and backwards exceeded 10,000 carrying around 800,000 containers of goods. 48 Chinese cities are now connected by routes with 42 cities in 14 countries of Europe. Instead, maritime communication still remains an important trading channel between Asia and Europe, that is why China builds new ports and upgrades old ones in Asia as well as in Europe ${ }^{39}$.

Total trade between China and the countries and regions involved in Belt and Road Initiative exceeded \$ 6 trillion. In 2018, however, China signed 171 cooperation agreements with 29 international organizations and 123 countries, including developed countries as well as developing ones ${ }^{40}$.

For the next step, the ministry is going to launch new collaboration platforms, including the second ${ }^{41}$

Ukraine also expects to take advantage of Chinese platform of the Belt and Road Initiative to strengthen cooperation with PRC in the sphere of transport, communication and infrastructure. This is facilitated by the favorable geographical location of Ukraine at the crossroads of major transit routes between Europe and Asia, the presence of 18 (five of which in the temporarily occupied territory) non-freezing ports of the Black Sea, an extensive network of railways and roads. Today, this is a particularly urgent issue from the point of view of the Association Agreement with the EU and further integration of Ukraine into the transport system of the Europe-Asia-Europe Corridor. The

38 Китайський проект «Один пояс, один шлях» та його можливості для України [Електронний ресурс]. - 2018. - Режим доступу до ресурсу: https://hvylya.net/analytics/ economics/kitayskiy-proekt-odin-poyas-odin-shlyah-ta-yogo-mozhlivosti-dlya-ukrayini.html

${ }^{39}$ Пятилетнее путешествие Пояса и Пути [Електронний ресурс]. - 2018. - Режим доступу до ресурсу: https://nv.ua/ukr/world/countries/pjatirichna-podorozh-pojasom-i-shljakhom2496956.html

${ }^{40}$ China's trade with BRI countries, regions crosses \$6t [Електронний pecypc]. - 2019. Режим доступу до ресурсу: http://www.chinadaily.com.cn/a/201903/06/WS5c7f4742a3106c65 c34ed150.html

${ }^{41}$ Largest exhibition of imported goods and services - "China International Import Expo" [Belt and Road cooperation presents fruitful results [Електронний ресурс]. - 2018. - Режим доступу до ресурсу: http://en.people.cn/n3/2018/0319/c90000-9438950.html. 
largest port of Ukraine is the Port of Odessa which is also the hub of the $9^{\text {th }}$ Trans-European Corridor. It is also worth mentioning the completion of the reconstruction of the Beskid Tunnel, a strategic one from the point of view of the delivery of transit cargo towards the European countries and which is a part of the 5th Pan-European Transport Corridor (Hungary-Slovakia-Ukraine). With all the above mention capabilities Ukraine strives to become a kind of a bridge between Asia and Europe turning the existing potential into a business prospect. Ukraine can offer rail, sea and air services and act as an important transport hub in the process of supplying Chinese goods to European markets and production of home and European producers back to China. Ukraine provides maximum acceptable conditions for cargo transportations through seaports of 58 countries, including the VIKING Train and ZUBR Train transportation services, with help of ferry services of the Trans-Caspian International Corridor ${ }^{42}$.

Thus, the Belt and Road concept can be called a global economic project, because since 2013 it already covers more than 65 countries and consists of two parts: Silk Road Economic Belt and the 21st Century Maritime Silk Road.

\section{CONCLUSIONS}

This study analyzes in detail the free trade agreements signed between China and China in the years 2001-2018 with the following countries: Georgia, Republic of Korea, Iceland, New Zealand, ASEAN, Chile, and Singapore.

It is established that after 2013, China has stepped up its activity to conclude or update its free trade agreements. The main reason, in our view, is the global Chinese One Belt One Way initiative (which began operations in 2013), which envisaged strengthening relations with as many countries as possible.

Overall, in 2019, China announced that it will start reducing or lowering import tariffs for 706 products starting January 1, with the aim of reducing consumer spending. While the first two rounds of tariff cuts in China focused mainly on consumer goods and manufactured goods, the last round affects a wide range of commodities such as cotton, fur, some pharmaceutical raw materials, and will continue to temporarily reduce tariffs on products such as aircraft engines, welding jobs and natural channels.

An in-depth analysis of the concept of "One Belt, One Way" as a strategically important global economic project of China has been carried out, since since 2013 it has already covered more than 65 countries and consists of two parts: "Silk Road Economic Belt" and "21st Century Silk Road".

${ }^{42}$ Asian infrastructure investment bank [Електронний ресурс] // Official website of Asian infrastructure investment bank. - Режим доступу. - URL: http://www.aiib.org 


\section{SUMMARY}

Summarizing the above, we conclude that the current directions of China's foreign trade policy are the introduction of a more active import policy with the simplification of trade procedures, development of new types of trade, promotion of innovative development, creation of a more attractive investment environment, strengthening of the protection of ownership rights., the creation of a new platform for international cooperation "One Belt, One Way" and the creation of new free trade areas

\section{REFERENCES}

1. Висоцька М. Аналіз основних тенденцій розвитку економічних відносин між Україною та Китаєм / М. Висоцька, А. Аль Атті // Стратегія розвитку України. Економіка, соціологія, право. - 2013. - № 4. - С. 14-20, с. 14.

2. China's Free Trade Agreements [Електронний ресурс]. - 2019. Режим доступу до ресурсу: http://fta.mofcom.gov.cn/english/fta_qianshu.shtml

3. Free Trade Agreements under Negotiation [Електронний pecypc]. 2019. - Режим доступу до pесурсу: http://fta.mofcom.gov.cn/english/ fta_tanpan.shtml

4. Asia-Pacific Trade Agreement [Електронний pecypc]. - 2018. Режим доступу до ресурсу: http://fta.mofcom.gov.cn/topic/enpacific.shtml.

5. The 53rd Asia-Pacific Trade Agreement Standing Committee Meeting and Related Panel Meetings Held in South Korea [Електронний pecypc]. - 2018. - Режим доступу до pecypcy: http://fta.mofcom.gov.cn/ enarticle/enpacific/enasiapacificnews/201809/38904_1.html.

6. China-Georgia FTA Comes into Force Today [Електронний pecypc]. - 2018. - Режим доступу до ресурсу: http://fta.mofcom.gov.cn/ enarticle/chinageorgiaen/chinageorgiaennews/201801/36885_1.html.

7. Georgia-China free trade deal comes into play from January 2018 [Електронний ресурс]. - 2018. - Режим доступу до ресурсу: http://agenda.ge/en/news/2018/29

8. China ranks 3rd for Georgia's wine exports in 2018 [Електронний pecypc]. - 2019. - Режим доступу до ресурсу: http://www.xinhuanet.com/ english/2019-01/05/c_137720361.htm.

9. The 2nd Joint Commission on China-ROK FTA Held in Seoul [Електронний ресурс]. - 2018. - Режим доступу до ресурсу: http://fta.mofcom.gov.cn/enarticle/enkorea/enkoreanews/201808/38460_1.html.

10. South Korea's Top Trading Partners [Електронний ресурс]. 2019. - Режим доступу до pecypcy: http://www.worldstopexports.com/southkoreas-top-import-partners/.

11. The 3rd Meeting of Joint Committee of China-Iceland FTA Held in Iceland [Електронний ресурс]. - 2018. - Режим доступу до ресурсу: http://fta.mofcom.gov.cn/enarticle/eniceland/enicelandnews/201809/38980_1.html 
12. Top Iceland Exports [Електронний ресурс]. - 2019. - Режим доступу до pесурсу: http://www.worldsrichestcountries.com/top-iceland-exports.html

13. The 5th Round of Upgrading Negotiation of China-New Zealand Free Trade Agreement Held in Beijing [Електронний ресурс]. - 2018. Режим доступу до ресурсу: http://fta.mofcom.gov.cn/enarticle/ ennewzealand/ ennewzealandnews/201809/38897_1.html

14. New Zealand-China FTA overview [Електронний ресурс]. - 2018. Режим доступу до ресурсу: https://www.mfat.govt.nz/en/trade/free-tradeagreements/free-trade-agreements-in-force/china-fta/nz-china-fta-overview/.

15. The 11th Joint Commission on China-ASEAN FTA Held in Beijing [Електронний ресурс]. - 2018. - Режим доступу до ресурсу: http://fta.mofcom.gov.cn/ enarticle/enasean/chianaseannews/201803/37518_1.html.

16. ASEAN-China trade boosting growth [Електронний ресурс]. 2018. - Режим доступу до pecypcy: http://global.chinadaily.com.cn/a/ 201811/19/WS5bf1f6a6a310eff303289619.html

17. China and ASEAN doing well on economic, trade cooperation [Електронний ресурс]. - 2019. - Режим доступу до ресурсу: https://www.thejakartapost.com/academia/2019/01/31/china-and-asean-doingwell-on-economic-trade-cooperation.html

18. The Protocol Upgrading China-Chile Free Trade Agreement Comes into Force Today [Електронний ресурс]. - 2019. - Режим доступу до ресурсу: http://fta.mofcom.gov.cn/enarticle/enchile/enchilenews/201903/39927_1.html

19. China-Chile FTA Upgraded, New Opportunities for Investors [Електронний ресурс]. - 2019. - Режим доступу до ресурсу: https://www.china-briefing.com/news/china-chile-fta-upgraded-marketopportunities-investors/

20. China and Singapore Sign Protocol to Upgrade the Free Trade Agreement [Електронний pecypc]. - 2018. - Режим доступу до ресурсу: http://fta.mofcom.gov.cn/enarticle/singaporetwoen/singaporetwoennews/20181 1/39360_1.html

21. Biggest fall in Singapore exports in over two years [Електронний pecypc]. - 2019. - Режим доступу до ресурсу: https://www.straitstimes.com/ business/economy/biggest-fall-in-spore-exports-in-over-two-years

22. New Tariff, Export Duty Cuts in China for 2019 [Електронний pecypc]. - 2019. - Режим доступу до pecypcy: https://www.chinabriefing.com/news/new-tariff-export-duty-cuts-china-2019-wide-varietyproducts-affected/

23. What is One Belt, One Road in China? [Електронний ресурс]. 2017. - Режим доступу до ресурсу: https://www.quora.com/What-is-OneBelt-One-Road-in-China 
24. Один пояс, один шлях [Електронний ресурс]. - 2018. - Режим доступу до ресурсу: http://agora-web.jp/archives/2035163.html

25. Один пояс, один шлях [Електронний ресурс]. - 2017. - Режим доступу до ресурсу: http://sinologist.com.ua/odin-poyas-odin-shlyahglobalnij-geoekonomichnij-proekt-kitayu]:

26. Пятилетнее путешествие Пояса и Пути [Електронний ресурс]. 2018. - Режим доступу до pecypcy: https://nv.ua/ukr/world/countries/ pjatirichna-podorozh-pojasom-i-shljakhom-2496956.html

27. One Belt - One Road [Електронний ресурс]. - 2017. - Режим доступу до ресурсу: http://www.textilevaluechain.com/index.php/article/ industry-general/item/1272-one-belt-one-road-china-s-big-initiative-creatingmassive-business-opportunities-sourced-compiled-by-arvind-sinha

28. Китайський проект «Один пояс, один шлях» та його можливості для України [Електронний ресурс]. - 2018. - Режим доступу до ресурсу: https://hvylya.net/analytics/economics/kitayskiy-proekt-odin-poyas-odinshlyah-ta-yogo-mozhlivosti-dlya-ukrayini.html.

29. Евро и юань могут потеснить доллар в глобальной торговле [Електронний ресурс]. - 2018. - Режим доступу до ресурсу: https://finance.liga.net/ ekonomika/novosti/v-perspektive-dollar-mojet-poteryatmirovoe-gospodstvo---prognoz; Юань став резервною валютою і потіснив євро [Електронний ресурс]. - 2016. - Режим доступу до ресурсу: https://www.dw.com/uk/юань-став-резервною-валютою-і-потіснив-євро/a35931655

30. Пакистан - Валовой внутренний продукт [Електронний ресурс]. 2019. - Режим доступ до ресурсу: https://knoema.ru/atlas/Пакистан/ВВП

31. China's trade with BRI countries, regions crosses $\$ 6 t$ [Електронний pecypc]. - 2019. - Режим доступу до ресурсу: http://www.chinadaily.com.cn/ a/201903/06/WS5c7f4742a3106c65c34ed150.html

32. largest exhibition of imported goods and services - "China International Import Expo" [Belt and Road cooperation presents fruitful results [Електронний ресурс]. - 2018. - Режим доступу до ресурсу: http://en.people.cn/n3/2018/0319/c90000-9438950.html.

33. Asian infrastructure investment bank [Електронний ресурс] // Official website of Asian infrastructure investment bank. - Режим доступу. URL: http://www.aiib.org

\section{Information about the author:}

Korol M. M.,

$\mathrm{PhD}$ in Economics,

Associate Professor at the International Economic Relations Department,

Uzhhorod National University 14, Universytetska str., Uzhhorod, 88000, Ukraine 


\section{RELIGION AND CHURCH IN CENTRAL AND EASTERN EUROPE}

\section{Palinchak M. M.}

\section{INTRODUCTION}

World War II changed the course of history of Central and Eastern Europe. Traditionally, being a frontier or half-division of the West, the region has become a Western continuation of the Soviet Union. Czechoslovakia, Poland and Hungary were in a semi-colonial dependence on the USSR, which was far behind them in the cultural, social, economic and political terms [see ${ }^{1}$, p. 292-302].

Churches in Central and Eastern European countries, even in the Soviet period, were officially recognized as an important factor in the preservation of national identity, and emphasized on the fruitfulness of their efforts in the area of raising social morality and patriotic education.

The fact that the churches, contrary to everything, played a positive role in peaceful revolutions, accelerating the collapse of the communist regime, confirms that totalitarian regimes always fail in their attempts to abolish religion. Moreover, anti-religious propaganda and persecution of believers indirectly worked on the authority of churches, and their influence in society became more significant.

Analysis of recent research and publications. A significant contribution to the study of this topic was made by domestic and foreign scientists. To name a few Barnackevich Yu., Burakov Yu.V., Kiparenko G.M., Movchan S.P., Moroz Yu.M., Vandich P., Yelensky V., Konotop L.G., Kril M.M., Mariansky Ya., Ovsienko F. G., and others.

The purpose of this study is to analyze the state - church relations in the countries of Central and Eastern Europe.

Research results. Since 1948, communism in Central and Eastern Europe has acquired its extreme form - Stalinism, for which there is a strict homogeneity in the imitation of the Soviet model and subordination to Moscow. "Love for the Soviet Union does not suffer any reservations," wrote the Czechoslovak newspaper "Red Law" on May 25, 1952. [Cite: ${ }^{2}$, p. 306].

${ }^{1}$ Вандич П. Ціна свободи. Історія Центрально-Східної Європи від Середньовіччя до сьогодення / П. Вандич. - К.: Критика, 2004. - 463 с.

${ }^{2}$ Вандич П. Ціна свободи. Історія Центрально-Східної Європи від Середньовіччя до сьогодення / П. Вандич. - К.: Критика, 2004. - 463 с. 
Most modern researchers focus on the rule in the communist era in Central and Eastern European of totalitarian model of rigid and antagonistic separation of church and state $\left[{ }^{3}\right.$, p. 31]. This model, with a greater or lesser consistency, was realized by the USSR, whose amplitude of religious policy was more than tangible: from the bloody terror at one pole, which destroyed more than 50 thousand only Orthodox clergy, to the imperial policy of introducing the "main church of the main people" into the system of state propaganda; from quite serious attempts to "finally resolve the religious issue" to the so-called "religious nep" and to direct the priests to the "Soviet patriotism".

In its "middle values", this model, is typical of most countries of the former "socialist camp," boiled down to total control over religious activity, its almost total restriction on the cult sphere, repression against religious dissidents, priests and ordinary believers who prevented the nomenclature. This model was also aimed, on the one hand, at creating a strong infrastructure for eradicating "religious prejudice" and, on the other, for using the church hierarchy in foreign policy to promote the "peace" of the Warsaw Pact and the benefits of the "socialist way of life." Under these conditions, religious freedom in Central and Eastern European countries was, at these times, a dead law that remained only on paper on which the Constitutions were written [See details: ${ }^{4}$ ].

As for religion in Poland, it can be stated with certainty that the Church and the Polish state have a tendency to maintain tolerant relations, but this was not always the case. In general, more or less tolerant links existed before the implementation of communist laws in Poland after World War II. Even today, an influential political force - the intelligentsia - continues to treat the church with distrust as an alien power that also interferes with state life. And looking back, it is clear that this minority has disagreed with the rule of Catholicism for centuries.

During the period of the Second Polish Republic (1918-1939), speeches against the church of certain population groups occurred as often as during periods of domination of foreign political regimes on the territory of Poland. However, in the interwar period, the state and the church generally coexisted in harmony. They entered into mutually beneficial agreements that constrained the Roman Catholic Church's anti-regime performances as a recognized national denomination. "Even under favorable conditions, Caesar and the Lord are not the best partners," the Poles said, citing the rule of Roman law [ ${ }^{5}$, s. 160].

3 Єленський В. Є. Релігійно-суспільні зміни в посткомуністичній Європі / В. Є. Єленський // Людина і світ. - 1999. - № 7. - С. 30-33.

${ }^{4}$ Государства и религии в Европейском Союзе (опыт государственно-конфессиональных отношений) / Под ред. Г. Робберса. - М. : Институт Европу РАН, 2009. - 719 с.

5 Religiöser Wandel in den postcommunistischen Landern Ostund Mitteleuropas. Wurzburg, 1998. - $176 \mathrm{~s}$. 
The 20-30s in Poland were characterized by intra-state confrontations, disputes between the government and the Vatican, the government and certain segments of the population regarding the attitude of the Holy See to the possible independence of Poland in church and religious aspect, since the Vatican ruling top did not want to influence life of the Polish public, wished to keep the Poles in subjection to obedience to the official Catholic doctrine. In turn, the government, under the reign of J. Pilsudski, was negative about the Vatican's desire to enslave the people because of the domination of religion and the church in the state, and the ruling top Catholic priests to govern the state and the people. Realizing this, the Pope changed his policy and supported Y. Pilsudski, which slightly weakened the confrontation between officials and the religious leadership, but some of the influential representatives of the church remained forever opposed to the marshal $\left[{ }^{6}\right.$, s. 200-201].

Although the legal framework was borrowed from the Soviet Union in the late 1940s, the Church's profound influence on the social and political life of the Poles could not be ignored when new laws were passed. In socialist Poland, the land was left in the possession of the church, parishes and monasteries were allowed to have up to 50 hectares of land, the state government financially subsidized religious associations and paid wages.

The system of separation of church and state could not be implemented by a single act. The process was initiated by the Manifesto of the Polish Committee of National Liberation on June 22, 1944, and the specific foundations of the political policy of the People's Republic of Poland were reflected in the 1952 Constitution $\left[{ }^{7}\right]$, which abolished the concordat and stated that relations between the state and the church were determined exclusively by the state laws. Article 69 of the Constitution guaranteed citizens, regardless of their attitude to religion, equal rights in all spheres of political, economic and cultural life. The state has declared protection of the freedoms of believers and atheists. It should be noted that the forms of this regulation were too general and symbolic. This resulted in the freedom of conscience not being fully guaranteed by the action of specific legal mechanisms, which gave rise to many difficulties in implementing its principles. The country's church was not endowed with legal personality [ ${ }^{8}$, s. 127$]$. Similar shortcomings occurred in the Constitution of the People's Republic of Poland in 1976; the main one was the

${ }^{6}$ Tretera J. R. Church and State in the Czech Republic / J. R. Tretera // European Journal for Church and State Research. - Peeters, Leuven. - 2001. - Vol. 8. - P. 287-294.

${ }^{7}$ Конституция и основные законодательные акты Польской Народной Республики. Пер. с польского. - М. : Политиздат, 1953. - 420 с.

${ }^{8}$ Krukowski J. Problematuka osobovosci prawnej kosciola katolickiego w relacji do panstva / J. Krukowski // Roczniki teologiczno-kanoniczne / Kom. Red. : T-wo nauk. Katolickiego uniw. Lubelskiego. - Lublin, 1978. - S. 122-146. 
non-recognition of the legal personality of a legal entity by the church $\left[{ }^{9}\right]$. This did not correspond to the real status of the church in the state, so there were frequent conflicts on this basis. The authorities of Poland have made a mandatory oath for priests $\left[{ }^{10}\right.$, p. 123]. Following the example of an "elder brother", a state body, the Ministry of Religious Affairs under the Cabinet of Ministers of the People's Republic of Poland, was created to monitor the observance of legislation on religion and the church.

In terms of the relationship of religion and church Poland declared principle of the secular nature of the state and neutrality with respect to the outlook of its citizens. Socialist countries generally (with the exception of Albania) recognized freedom of conscience and religion up to the right to spread religious or atheistic views. These ideas were reflected in the Constitutions of the Warsaw Pact [See: ${ }^{11}$ ]. In practice, the peculiarity of state-church relations in socialist countries was the subordination of religious policy to official ideology. The result was a contradiction between constitutional theory and real life. The state, using various means of coercion, restricted freedom of conscience and religion. In the Polish Constitution and legislation on religious freedom, the rights of religious associations narrowed mainly to the function of satisfying religious needs in prayer houses. Cultural, educational and other activities were banned. The Constitution of the People's Republic of Poland formally, symbolically regulated the state-church relations. In declaring freedom of conscience and religion, the Basic Law of the Polish Republic did not indicate the specific rights of citizens that should follow from the proclaimed freedom, and the law did not recognize the rights of legal entities under ecclesiastical organizations. It is no coincidence that $69 \%$ of Poles positively evaluate the role of the church that it played during the communist regime. However, in 1989-1993 the number of critics of the church increased; $50 \%$ of respondents accused it of "interfering in politics" [ $\left[{ }^{12}\right.$, s. 157-169].

In the 1980s, religious movements and communities associated with the Catholic Church developed in Poland. In the late 1980s, religious movements of a sectarian nature began to develop widely. Some of them called themselves Christian, others were inspired by the religions of the East, while others became

9 Сленський В. Є. Релігійно-суспільні зміни в посткомуністичній Європі / В. Є. Сленський // Людина і світ. - 1999. - № 7. - С. 30-33.

10 Юскаев Н. Х. Из опыта взаимодействия армии и церкви в некоторых восточноевропейских странах / Н. Х. Юскаев // Религия, церковь в России и за рубежом: Информационно-аналитический бюллетень. - 1998. - № 3-4. - С. 120-129.

11 Конституции социалистических государств. - В 2-х т. - М. : Юридическая литература, 1987. - Т. 1;2.

12 Religiöser Wandel in den postcommunistischen Landern Ostund Mitteleuropas. Wurzburg, 1998. - $176 \mathrm{~s}$. 
echoes of existing socio-political ideologies. Often they offer substitutes and symbolic equivalents of religious experience. Activities of sects and new religious movements are carried out mainly in selected social groups of strategic importance (for example, among young people). The expansion of new religious movements continued in the $1990 \mathrm{~s}\left[{ }^{13}\right.$, p. 110-111]. Against this background, the new social situation has led to the need to think about what is religion and what is not, as well as a partial departure from the theories and methods to religion's sociology of that time.

The communist period is well characterized by the metaphor of the church as being "surrounded by a stronghold." At the same time, this did not mean identifying all Catholics with the official model. Poland also experienced a virtually inconspicuous and fragmentary modernization, which also caused changes in religiosity: selectivity in adopting faith and observing moral Catholic norms, especially in the area of rituals and customs. The presence of such features of religiosity leads to the conclusion that there has been an implicit privatization of religion after the Second World War in Poland $\left[{ }^{14}\right.$, p. 223-233]. The church has transformed with a great deal of public respect and trust; This is evidenced by the fact that in the socialist state in the $1980 \mathrm{~s}$, according to various polls, about $80 \%$ of the population declared their belief that the church was properly serving the public interest. The internal tensions in the church environment related to Catholic reform figures were unknown to the general public. There has been no public debate on religion, church or morality. The Church appeared to be a strong, compact, emphatic clerical authority (as opposed to a weak and powerless worldly community), disciplined, with a hierarchical structure $\left[{ }^{15}\right.$, s. $22-23 ;{ }^{16}$, s. 12$]$.

The anti-communist movement in Poland and the associated "religious thaw" took on a new dimension after the event that took place in Rome in late 1978: the election of Cardinal Pope John Paul II. The following year, the Herek regime allowed his visit to his homeland. The celebrations, which were attended by huge crowds, provided the Union's intellectuals, workers, and churches with a new, nationwide, patriotic and ethical dimension. The people also realized their power against the party and the state apparatus, which could do nothing but

13 Маріянський Я. Суспільний характер релігії / Я. Маріянський // Релігія в сучасному світі: Матеріали до курсу релігієзнавства / За ред. Г. Зімоня. - Переклад 3 польської Г. Теодорович. - Л. : Свічадо, 2007. - 504 с. - С. 97-125.

${ }^{14}$ Borowik I. Odbudowanie pamięci. Przemiany religijne w środkowo-wschodniej Europie po spadku komunism / I. Borowik. - Krakow : Zakład Wydawniczy NOMOS, 2000. - 248 s.

${ }^{15}$ Gowin Por. J. Kościół po komunizmie / J. Por. Gowin // Znak. - Kraków, 1995. - S. 22-23.

${ }^{16}$ Piwowarski W. Socjologia religii / W. Piwowarski. - Lublin: Redakcja Widawnictw Katolickiego Uniwersytetu Lubelskiego, 1996. - 98 s. Pravo Wyznaniowe. Ustawa z dnia 17 maja 1989 r. O gwarancjach wolności sumienia i wyynania. - Warszawa, 1989. - 396 s. 
small oppression. "During the papal visit," says American historian of Polish descent P. Wandicz, "Poland was another, was a free country" [ ${ }^{17}$, p. 322 - 323].

This landmark event in the history of Poland created new conditions for the regulation of state-church relations. In the early 1980s, the authorities began to eliminate obstacles to religious freedom. The result was a revival of religious life, which led to an increase in the number of religious communities, the construction of new religious buildings, the liberalization of legislation on freedom of conscience and the activities of religious organizations.

In 1980-1981, Polish believers were given the opportunity to regularly listen to the worhip on the state radio network. A joint commission has been set up between the government and the Episcopate to work on the legal settlement of the problematic issues. The Polish government, under pressure from the opposition, was forced to take the initiative to formally negotiate with the leadership of the Roman Catholic Church in order to determine the status of the latter in the state. The negotiations lasted for several years and resulted in the adoption on May 17, 1989 of three laws: "On the Relations between the State and the Roman Catholic Church"; "On Guarantees of Freedom of Conscience and Religion"; "On the social security of the clergy." The content of these laws has been brought into line with the country's international human rights obligations [ ${ }^{18}$, p. 154]. The Church of Poland became a powerful force, playing an important role in the preparation of the 1989 peace revolution. According to the publicist E. Sardykowski, the church in the life of the Polish people was, "firstly, a national flag, secondly aimed at Marx, and thirdly, the only testimony of truth and freedom" [Cite: ${ }^{19}$, p. 13]. Poland was the first country in the socialist camp to adopt a package of documents, which was an important step towards the promotion of democracy, civil rights and freedoms $\left[{ }^{20}\right.$, p. 9].

It is noteworthy that Poland became the first Eastern European country to consolidate at the constitutional level the right of citizens to replace military service. In June 1988, the Seimas of Poland introduced a new form of military service - a replacement alternative service. In January 1991, the decree of Pope John Paul II restored the Polish military hierarchy. The congregation of bishops

${ }^{17}$ Вандич П. Ціна свободи. Історія Центрально-Східної Свропи від Середньовіччя до сьогодення / П. Вандич. - К.: Критика, 2004. - 463 с.

18 Овсиенко Ф. Г. Взаимоотношения государства и церкви в странах Восточной Европы / Ф. Г. Овсиенко // Мировой опыт государственно-церковных отношений : Учебное пособие / Под общ. ред. Н. А. Трофимчука. - М. : Изд-во РАГС, 1998. - 306 с.

${ }^{19}$ Конотоп Л. Г. Головні характеристики містики: структура і зміст (в контексті релігійної антропології) / Л. Г. Конотоп, В. Л. Хромець // Антропологічні виміри езотеричної філософії. - Слов'янськ Печатний двір, 2005. - С. 43-51.

20 Барнакевич Ю. Правовые основы гарантий свободы совести в Польской Республике: Автореф. дис. ...канд. филос. наук / Ю. Барнакевич. - М., 1990. - 22 с. 
approved the statute of the Polish diocese $\left[{ }^{21}\right.$, p. 288]. Chaplains are a separate corps of servicemen, led by the Chief Field Bishop [ ${ }^{22}$, p. 168].

Legal principles of state-confessional relations in the new postcommunist conditions, the scope of the rights of believers were defined by the Law of the Polish Republic of "On guarantees of freedom of conscience and religion [ ${ }^{23}$, s. 347-368], May 17, 1989, as amended on June 26, 1997. In accordance with Article 1, the Republic of Poland guarantees to every citizen the freedom of conscience and religion, which is the freedom to choose religion and religious beliefs, their expressions individually and collectively, private and public. Believers of all religions, as well as non-believers, have equal rights in state, political, economic, social and cultural life. The government promotes religious denominations and creates no obstacles to their activities. In accordance with the law and the norms of the Constitution, citizens have the right: to establish religious communities (churches and other religious organizations) in order to recognize and spread the religious faith; participate in religious activities and ceremonies as well as perform religious duties and celebrate religious holidays; to spread their religion and beliefs, to educate their children according to their own beliefs in the religious spirit; not to disclose their religious preferences; to participate in the work of international religious organizations; use sources of information on religion; produce and buy items needed for religious purposes and religious ceremonies; to become a priest or a monk; to be buried in accordance with a religious ritual or belief. But the law also provides for restrictions imposed by the state in the exercise of these rights, as evidenced by Article 3: "Individual or collective expression of one's religion or belief may be restricted by law only in the interests of public safety, order, health or morals of the population or legal rights and freedoms of others. Freedom of conscience and religion may not be a cause of release from the performance of public duties required by law" $\left[{ }^{24}\right.$, s. 350].

Thus, Poland has now become a religiously and ideologically pluralistic country. However, this pluralistic denomination of faiths and a certain circle of unbelievers do not weaken the eloquent phenomenon of the vast majority of Catholics in the country. 95\% (according to other 89\%) of the 2 million inhabitants are Roman Catholics, ie even more than those who profess their

${ }^{21}$ Мировой опыт государственно-церковных отношений : Учебное пособие / Под общ. ред. Н. А. Трофимчука. - М. : Изд-во РАГС, 1998. - 306 с.

22 Овсиенко Ф. Г. Взаимоотношения государства и церкви в странах Восточной Европы / Ф. Г. Овсиенко // Мировой опыт государственно-церковных отношений : Учебное пособие / Под общ. ред. Н. А. Трофимчука. - М. : Изд-во РАГС, 1998. - 306 с.

${ }^{23}$ Rahner K. Atheismus / K. Rahner // Sacramentum mundi. Theologisches Lexikon für Praxis. - Bd1/Hrsg K. Rahner, A. Darlap. - Freiburg, 1967. - S. 372-383.

${ }^{24}$ Rahner K. Atheismus / K. Rahner // Sacramentum mundi. Theologisches Lexikon für Praxis. - Bd1/Hrsg K. Rahner, A. Darlap. - Freiburg, 1967. -S. 372-383. 
faith in God. Therefore, the Catholic Church was and remains a reputable spiritual power in Poland's political arena. It has a strong branched infrastructure that has evolved even in communist times. The number of priests (nearly 30,000) allows the church to send missionaries to countries in Europe, Asia, Africa and America [ ${ }^{25}$, p. 447].

In Hungary, as in most countries of Central and Eastern Europe, in the late 1940s, a state system of a totalitarian type, mounted on a Soviet bastard, prevailed. This system was immediately doomed to permanent socio-political crises.

Having seized power with the help of the Soviet special services in March 1948, the Hungarian Communists under the leadership of M. Rakoshi, the leader, abolished democratic institutions - human rights and the rule of law. In Hungary, the increasingly severe restriction of religious activity in 1945-1948 changed to brutal terror against the Catholic Church. In 1948, the head of the Church of Cardinal Jozef Mindsenti was arrested and convicted on charges of "anti-state activity" $\left[{ }^{26}\right.$, p. 160]. They made mass arrests, suppressed the slightest manifestation of dissent. "Enemies" were searched and "found" even among the communist leadership. An atmosphere of fear and oppression prevailed in the country $\left[{ }^{27}\right.$, p. 101]. Following the example of the "elder brother," the local nomenclature significantly restricted the activities of the churches and the prerogatives of the clergy. The church was not to go beyond the altar and the confessional. In accordance with the new requirements for the appointment of bishops of the Catholic, Evangelical and Reformed churches, the prior consent of the Presidium of the Hungarian People's Republic was required. For appointment to other ecclesiastical positions, the prior consent of the State Administration for Religious Affairs - controlled by the special services of the bureaucratic body - was required $\left[{ }^{28}\right.$, p. 442].

Many issues of state-church relations in Hungary were resolved by concluding treaties between the state and specific churches: the Reformed (October 7, 1948), Lutheran (December 14, 1948), and Catholic (August 30, 1950). Pursuant to these agreements, churches in the country could, on a limited scale, carry out religious and outreach activities, engage in missionary and

${ }^{25}$ Рынковский М. Государство и церковь в Польше // Государства и религии в Европейском Союзе (опут государственно-конфессиональнух отношений) / Под ред. Г. Робберса. - М. : Институт Европы РАН, 2009. - 719 с. - С. 447-470.

${ }^{26}$ Бураков Ю. В., Кипаренко Г. М., Мовчан С. П., Мороз Ю. М. Всесвітня історія. Новітні часи. 1945-1996 : Підручник. - К. : А.С.К., 1998. - 320 с.

${ }^{27}$ Шанда Б. Государство и церковь в Венгрии / Б. Шанда // Государства и религии в Европейском Союзе (опут государственно-конфессиональнух отношений) / Под ред. Г. Робберса. - М. : Институт Европу РАН, 2009. - 719 с. - С. 97-126.

${ }^{28}$ Палінчак М. М. Держава і церква у постсоціалістичних суспільствах (на прикладі країн Центральної Європи та України): Монографія. - Ужгород: Поліграфцентр «Ліра», 2014. $-408 \mathrm{c}$. 
charitable activities, receive financial assistance from the state, etc. Religious education in public schools was allowed only on an optional basis $\left[{ }^{29}\right.$, p. 442].

The death of Stalin in 1953 and the beginning of the political thaw in the USSR had a positive impact on developments in the countries of Central and Eastern Europe. The communist leaders of the satellite countries were forced to carry out some, albeit bold and inconsistent, liberalization of the political course, which somewhat reduced the level of discontent and indignation of the mainstream regimes, but not everywhere.

The 20th Congress of the CPSU (1956) had an even greater influence on the European countries of "popular democracy, and criticism of the "cult of person" that was discussed there, was the first attempt to tell tell the truth about the Stalin's horrific crimes". Impressed by these developments, a broad democratic movement began in some countries of Central and Eastern Europe, whose members demanded the establishment of civil and political rights and freedoms, and the cessation of the slave-copying of the Soviet "experience." Given the specific conditions of totalitarian regimes, the reform supporters were forced to adhere to a "socialist" framework, calling only for the elimination of "distortions" of Leninist principles. The political situation in the countries of Central and Eastern Europe has escalated sharply, and a sharp political crisis has emerged in Poland, Hungary and the GDR. In Poznan (Poland), in June 1956, workers and youth rebelled. The suppression of this speech caused a new wave of outrage in the country. In autumn Poland was on the verge of a nationwide explosion. He managed to avoid it by changing the party-state leadership and sharpening the political course from rigid, repressive, to liberal.

At the same time, a people's revolution began in Hungary on October 23, 1956, which immediately swept the entire country and within a few days swept the Stalinist regime. Hungary was ready to withdraw from the communist bloc and join the European family of free democratic states, but the Soviet leadership could not accept this and decided to take armed intervention. Soviet army forces invaded Hungary, bringing with them a new Hungarianpeasant government formed in Soviet territory. The revolution was cruelly suppressed. Hundreds of its members, including former Prime Minister I. Nagy, have been executed, and thousands of others have been sentenced to long-term imprisonment [See: ${ }^{30}$, p. $131-161 ;{ }^{31}$, p. 288].

${ }^{29}$ Палінчак М. М. Держава і церква у постсоціалістичних суспільствах (на прикладі країн Центральної Європи та України): Монографія. - Ужгород: Поліграфцентр «Ліра», 2014. -408 c.

${ }^{30}$ Бураков Ю. В., Кипаренко Г. М., Мовчан С. П., Мороз Ю. М. Всесвітня історія. Новітні часи. 1945-1996 : Підручник. - К. : А.С.К., 1998. - 320 с.

${ }^{31}$ Країнознавство. Країни СНД, Свропи і Північної Америки: Навчальний посібник / М. С. Дорошко, Р. А. Кривонос, В. П. Крижанівський, Н. Ф. Сербіна. - К. : Ніка-Центр, 2009. $-312 \mathrm{c}$. 
During the revolutionary events, the Catholic Church hierarch, Cardinal J. Mindsenti, actively spoke on the side of opposition forces that attempted to overthrow the political regime. After the defeat of the uprising, the cardinal was forced to seek political asylum at the US Embassy in Hungary, where he spent 15 years, and in 1971 left for Rome. After the suppression of the 1956 revolution, Hungarian society lost its internal strength to open resistance to political pressure. This moral surrender completed the process of social destruction.

Fortunately, political terror was not lasting. The leader of the reorganized Hungarian Socialist Workers' Party (USRP) and Prime Minister J. Kadar proved to be a figure with a broad outlook and a non-standard way of thinking. Without violating the principle of "loyalty" to the Soviet Union, he also pursued a moderately liberal course that is substantially different from the conservative policies that prevailed in the rest of the Eastern Bloc countries. Consumption of calories per capita has considerably increased. In Hungary in the 60-80s of the twentieth century, there was virtually no manifestation of political opposition and, accordingly, no persecution of dissenters by the authorities. The Hungarians were able to visit the free world freely. In general, this period in the history of the country was half-jokingly called "goulash socialism", referring to the attempts of the Hungarian party elite to build an industrial and at the same time consumer communist society, where everyone was guaranteed a goulash - a favorite Hungarian dish.

After Y. Kadar's speech at the newly elected Hungarian Parliament in the fall of 1962 and the concordat of the Hungarian People's Republic with the Vatican on September 15, 1964, it becomes possible to talk about the relative normalization of state-church relations in the "hottest barracks" of the Communist camp. Formation of a relatively liberal attitude of the authorities to religious institutions has been delayed in this country for decades. Despite some liberalization of the regime, Hungarian religious scholars and sociologists state: Hungary experienced a deep religious decline in the 1960s and 1970s and an unexpected but steady increase in the religiosity of all ages since the late 1970s.

Some revival of religious life in the country was primarily due to the entry into the historic arena of the new generation. Its economic base was made up of small private businesses in agriculture and in the third sector of the economy. It found ideological support from religion, which upheld public relations. The end of the 1970s was a period when an exclusively rural and poorly educated church, the main contingent of which consisted of elderly parishioners, began to recede into the past. Those who secured religious revival (residents of cities and youth) had higher educational level and participated more actively in public life $\left[{ }^{32}\right.$, p. 2-10].

\footnotetext{
${ }^{32}$ Релігія і релігійність у посткомуністичній Європі. Цифри і факти без інтерпретацій // Людина і світ. - 1997. - Листопад-грудень. - С. 2-10.
} 
The collapse of communism in the late 1980s gave rise to new freedom and new problems. Finding a new place in Roman Catholic, Greek Catholic, Reformed, and other churches was difficult, as decades of communist rule led to significant and violent secularization of Hungarian society [See: $\left.{ }^{33}\right]$.

Hungarian scholars say that, unlike Catholic Poland, the Church in Hungary is weak, and the confessional picture in this country is complex and confusing. In the 1990s, Hungarian society was ideologically divided into three parts. About a third of its representatives said they attend church worship, but only less than half practice it more or less regularlyThe second part (from 30\% to $40 \%$ ) sympathizes with traditional forms of religiosity, but does not participate in traditional and institutional cult practices. They claim to be believers, though they do not actually belong to churches. The last third of Hungarian society defines itself as non-believers and demonstrably distances itself from religion and the church. But those who define themselves as atheists make up only $4-5 \%$ of the adult population.

Adhering to democratic values, the post-socialist countries of Europe proclaimed freedom of conscience and religion as the basis for regulating stateconfessional relations. In the early 1990s, Hungary signed a number of international agreements related to religious freedom. In particular, the International Convention on Civil and Political Rights, the European Convention for the Protection of Human Rights and Fundamental Freedoms with its Additional Protocols, and other documents were signed and ratified [ ${ }^{34}$, p. 102-103].

According to the Constitution in the Republic of Hungary the church is separated from the state. The state cannot create bodies to check the activities of the church and its organizations. According to $\S 60$ of the Hungarian Constitution, the right to freedom of conscience and freedom of religion combines the free choice of religion and the free imitation of other religious beliefs. Everyone has the right to practice his or her religious beliefs alone or with a group of people, in public or in private (at home, in the circle of their loved ones). The constitutional provision stipulates that a Hungarian citizen has the right not only to practice but also to promote his or her religious beliefs. To spread religious or other beliefs of conscience, the law provides for the possibility of using the media $\left[{ }^{35}\right.$, p. 60].

The religious freedoms of citizens are also protected by the Criminal Code of the Republic of Hungary. According to the "violation of freedom of

${ }^{33}$ Центрально-Восточная Европа во второй половине ХХ века. - В 3-х т. - Т. 3 : Трансформации 90-х годов. - М. : Наука, 2002. - 516 с.

${ }^{34}$ Шанда Б. Государство и церковь в Венгрии / Б. Шанда // Государства и религии в Европейском Союзе (опыт государственно-конфессиональных отношений) / Под ред. Г. Робберса. - М. : Институт Европу РАН, 2009. - 719 с. - С. 97-126.

${ }^{35}$ Конституція України. - К., 1997. - 80 с. 
religion and religion" provision, any person who, through violence and threats, interferes with another person's freedom to practice his religion, commits a crime punishable by imprisonment for a term up to three years. Violence, humiliation and abuse of anyone because of their belonging to a national, ethnic or religious group is punishable by imprisonment for a term up to five years $\left[{ }^{36}\right.$, p. $\left.120-121\right]$.

In 1997, Parliament changed the system of state subsidies to churches. Back in 1990, the first freely elected parliament decided to provide financial assistance to religious organizations on a permanent basis. This meant that each year Parliament was forced to divide the "church fund" of the central budget between different churches and denominations, depending on the number of parishioners and the "social role" of religious organizations. However, the number of parishioners could not be determined. The idea of including the question of religious affiliation in the census questionnaire was declared unconstitutional. During 2012, the Hungarian government provided HUF 35 billion (approximately US \$ 161 million) in additional funding for churches to undertake a range of activities, in particular to support the public collection of works of art; support for religious education, education and culture; payment of annual compensation for non-reclaimed religious property ("eternal life annuity"); promoting the work of church staff serving the smallest villages. 4 "historical" churches continued to receive $93 \%$ of the total state financial support provided to religious groups $\left[{ }^{37}\right.$, p. 2].

Thus, the fall of the communist regime, the change in the legal system affect the state-church relations in the Republic of Hungary. Changes to the basic legislation on freedom of conscience have led to the expansion of the confessional spectrum of existing religious associations. The nature of the activities of religious organizations changed significantly. Nowadays it includes not only cult practice but also social, cultural, educational and entrepreneurial activity. This has greatly expanded the field and the scope of interactions between the state, religious organizations, and the possibilities of their legal support. Religious influence is evident in education, armed forces, in the political life of the Republic of Hungary.

An analysis of the norms of the Constitutions of Hungary and other postcommunist states, as well as of international documents of a universal nature, shows that in the individual dimension the right to freedom of thought, conscience and religion covers the following freedoms:

- whether or not to profess religion or belief;

${ }^{36}$ Шанда Б. Государство и церковь в Венгрии / Б. Шанда // Государства и религии в Европейском Союзе (опыт государственно-конфессиональных отношений) / Под ред. Г. Робберса. - М. : Институт Европу РАН, 2009. - 719 с. - С. 97-126.

${ }^{37}$ Budapester Zeitung. - 2013. - 10 Januar. - S. 2. 
- have or have no religious education;

- to participate or not to participate in any form of worship, not to be directly or indirectly compelled to disclose their beliefs, to have free access to places of worship;

- not to give any oaths contrary to human beliefs;

- express their religious beliefs openly or declare no religious beliefs;

- not to perform military service with weapons if it is contrary to human beliefs, instead undergo alternative civilian service.

Collectively, the right to freedom of thought, conscience and religion includes the following freedoms:

- freedom to express their beliefs and to spread their religious beliefs, while protecting each person and group from coercion, the opportunity to spread their beliefs, and to practice the customs of their religion without the intervention or invasion of outsiders;

- freedom to form religious associations that may be registered in the general register of legal entities or in the register of religious organizations in order to obtain the legal status and rights of the legal entity; at the same time, unions of believers may operate without official registration;

- the freedom to acquire and hold places of worship, to hold and attend religious worships and events;

- freedom to create and govern religious organizations on the basis of self-government, as well as to communicate with other national or international associations of believers;

- produce, buy, import, export and distribute religious literature, printed and audiovisual material or objects used in religious activities;

- establish and manage private schools, and engage in educational, cultural, philanthropic and social activities;

- seek and obtain voluntary financial assistance from individuals and institutions to support their activities.

Therefore, in the process of socio-political transformation in Hungary, due to the developed culture of political consensus and the rapid revival of civil society structures, the process of socio-political structuring took place organically. In view of this, a stable modern European democratic political system has been established in the country. In the summer of 2000, the Hungarians celebrated the 1000th anniversary of statehood. A symbol of Hungary's special role in the civilizational dialogue between the West and the East was the recognition of King Istvan (Stefan), who is a Catholic saint, also as an Orthodox saint $\left[^{38}\right.$, p. 211].

${ }^{38}$ Кріль М. М. Історія країн Центрально-Східної Свропи (кінець ХХ т. - початок XXI ст.) : Навчальний посібник / М. М. Кріль. - К. : Знання, 2008. - 284 с. 
Another country that had a communist influence on state-church relations was Czechoslovakia. At the end of World War II, the Catholic Church in Czechoslovakia was almost destroyed. At the same time, having failed to revive a little after the Nazi occupation, it fell again under the wrath, but now under communist one. It is striking that Muscophile-minded President Benesch "brought Russia and communism to the borders of his state" $\left[{ }^{39}\right.$, p. 177].

After the communist revolution in February 1948, the so-called "scientific", Marxist-Leninist ideology based on atheism and the denial of God was introduced into all spheres of public life. During 1948-1989, atheism in Czechoslovakia actually played the role of state "religion". The ultimate goal of the regime was, of course, the complete elimination of religious associations. Relying on the notorious Stalinist thesis of the aggravation of class struggle during the construction of socialism, the leadership of the Communist Party of Czechoslovakia, like other Eastern European parties, used to repress the real and potential opponents of the regime by inflating the atmosphere in society. Religious institutions have come under close scrutiny by the authorities, special services agents have been infiltrated into the church administration, and religious dissidents have been subjected to repression. According to incomplete data, only during the period 1948-1953, more than 70,000 innocent people were repressed in Czechoslovakia. Almost all Catholic bishops were either arrested, sent to concentration camps, or expelled from the country - the situation changed only when the communist regime was overthrown in 1989The dictatorship in no way took into account the Modus Vivendi agreement signed in 1927 between representatives of the Czechoslovak government and the Holy See. It concerned the process of appointing bishops in the country and guaranteed mutual respect for the interests of both parties [See details: ${ }^{40} ;{ }^{41}$, p. $264-265 ;{ }^{42}$, p. $118-120$ ]. In fact, relations with the Vatican were severed.

In addition, the CCP sought to undermine the authority of the church through the so-called Catholic Action and Pacem in Terris, and also aimed at the venerable Archbishop of Prague-Beran. The archbishop was first isolated at his residence and later taken to a monastery. In 1951, due to the fierce pressure, nine out of thirty bishops and most of the lower clergy swore to be loyal to the new regime $\left[{ }^{43}\right.$, p. $\left.47-50\right]$.

${ }^{39}$ Vaško V. Kronika katolickě cirkve c Českoslovnsku po druhě světove válce / V. Vaško. Praha, 1990. $-231 \mathrm{~s}$.

${ }^{40}$ Kaplan K. Stát a cirkev v Českoslovnsku v letech 1948-1953 / K. Kaplan. - Brno : Doplněk, 1993. - 121 p.

${ }^{41}$ Kováč D. Dejiny Slovenska / D. Kováč. - Praha: Lidové noviny, 1998. - 401 s.

${ }^{42}$ Vaško V. Kronika katolickě cirkve c Českoslovnsku po druhě světove válce / V. Vaško. Praha, 1990. - $231 \mathrm{~s}$.

${ }^{43}$ Kaplan K. Stát a cirkev v Českoslovnsku v letech 1948-1953 / K. Kaplan. - Brno : Doplněk, 1993. - 121 p. 
The foundations of a qualitatively new level of state-church relations in the modern Czech Republic were laid by the events of November 1989, which became known as the "Gentle" ("Velvet") revolution. The dynamics of change in Czechoslovakia were unprecedented: by the fifth day of the revolution, the "defense strategy" of the leaders of the Communist Party of Czechoslovakia had collapsed. One Western journalist aptly remarked: "Something that took the Poles ten years, the Hungarians ten months, the citizens of the GDR ten weeks, the Czechs and Slovaks carried out in ten days!" [ ${ }^{44}$, p. 194]. The Communist Party, devoid of the confidence and support of the people, was quickly removed from government. The wave of popular indignation dropped it from the administrative-leadership throne, which it took once by itself and failed to confirm its rights. The autumn events of 1989 in Czechoslovakia were not accidentally called the "gentle revolution". Many thousands of demonstrations took place in a very organized manner, with a radical political turn in the country with almost no excesses. This happened mainly due to the existence in society of certain democratic traditions and rudimentary public structures (although very ghostly ones), a high degree of readiness for change of the population of the country, which was well aware of the hopelessness and foreignness of the imposed socio-political system.

The Velvet Revolution became a point of departure, signaling positive changes in the mutual relations of the state and religious organizations. The revolution found widespread support from the church and religious organizations $\left[{ }^{45}\right.$, p. 142]. Cardinal F. Tomaszek openly declared that he and the Catholic Church stand on the side of the people [ $\left.{ }^{46}, \mathrm{p} .17\right]$.

The Prague government has started a new church-state relations with the unsuccessful attempts to create a "national Catholic Church," which would have to break off relations with the Apostolic Capital. But in reality, government policy has led to the formation of parallel structures in the church and the emergence of dissident priests who have acted illegally without obtaining the permission of the authorities or the state content granted to registered clergy. The presence of priests of the so-called "catacomb church" has become a problem that the Vatican has failed to solve throughout the decade since the fall of communism. Even the visit of Pope John Paul II to the Czech Republic in May 1995 did not help in this case. Several Czech bishops, at one time,

${ }^{44}$ Історія Чехії очима українців : Навчально-популярне видання. - Ужгород : Гражда, 2009. -224 c.

${ }^{45}$ Cepliková M. K niektorým aspektam právnej úpravy vzt'ahov štátu a náboženských organizácii na našom územi po roku 1989 / M. Cepliková // Právny obzor: Bratislava. - 1999. № 2. - S. 140-147.

${ }^{46}$ Szostkiewicz A. Religion after Communism / A. Szostkiewicz // Commonweal. 09/24/99. - Vol. 126. - Issue 16. - P. 17-34. 
consecrated laymen with violations of the canon law of the Roman Catholic Church (celibacy, etc.), based on the real situation of state pressure. Only at the beginning of 2000 Congregation for the Doctrine of the Faith has given a final assessment of the situation in the Czech Republic, pointing out that Czech Catholics are members of the "Catacomb Church", they are not persecuted like the first Christians and must adhere strictly to the canon law. The tension between Prague and the Vatican can be explained by the following fact. During 2000-2002, representatives of the Czech Republic and the Apostolic Capital drew up an international agreement signed by them in June 2002. However, the House of Representatives by 110 votes to 90 did not recommend the government ratify the treaty, delaying its consideration until "more favorable times." [ ${ }^{47}$, c. 639-640].

Immediately after the "velvet" revolution, all anti-church articles of the Criminal Code and the legislative norm of communist times were abolished, which allowed the state to interfere in the process of appointment and approval of the clergy, preachers, and all ministers of the church. This principle was also confirmed in the Parliament and adopted by the Czech and Slovak Federal Republic (CSFR) on January 9, 1991 of the Charter of Fundamental Rights and Freedoms, which became an important part of the constitutional order of the Czech Republic. $\left[{ }^{48}\right.$, c. 486$]$.

Summing up, it should be noted that the state-church relations in the Czech Republic settled in accordance with international law. The state has done much to eliminate the recurrence of Czechoslovakia's communist regime's policies on religion and the church. A specific feature that has historical roots is a weak link between the majority religion and the national archetype and a low percentage of believers. It should also be noted that there has never been a regime of complete and rigid separation of the church from the state in the Czech Republic. Currently, the state adheres to the principle according to which it does not identify itself with any church, and the principle of equality and autonomy of churches. However, the state cooperates with churches in many areas. Church law specialists call this model of state-church relations cooperative [ ${ }^{49}$, p. 287-294].

It should be noted that by far the most tragic period in the history of the church on Slovak teritory was the communist one (1945-1989). The Catholic

47 Третера И. Р. Государство и церковь в Чехии / И. Р. Третера // Государства и религии в Европейском Союзе (опыт государственно-конфессиональных отношений) / Под ред. Г. Робберса. - М. : Институт Европы РАН, 2009. - 719 с. - С. 631-656.

${ }^{48}$ Конституція Чеської Республіки // Конституції нових держав Європи та Азії / Упорядник С. Головатий. - К. : Українська Правнича Фундація, вид-во «Право», 1996. $612 \mathrm{c}$.

${ }^{49}$ Tretera J. R. Church and State in the Czech Republic / J. R. Tretera // European Journal for Church and State Research. - Peeters, Leuven. - 2001. - Vol. 8. - P. 287-294. 
and Greek Catholic churches of Slovakia, which were a bone in the throat for the communist regime, in 1949 came under total state control. A year later, a national security campaign began, during which the monasteries were abolished overnight, and the monks were interned in "forced labor camps." The monasteries were soon liquidated. The terrorist regime tried to intimidate the church with loud political processes over bishops Ya. Voitashak and M. Buzalko. Y. Voitashak was sentenced to 24 years in prison and M. Buzalka to life imprisonment. The trial of Greek-Catholic Bishop P. Goydic, who was sentenced to life imprisonment, was closely linked to the Kremlin's liquidation by order of the Greek Catholic Church in Slovakia. The Orthodox Church became the owner of all its temples and property, and the Greek Catholics converted to the Orthodox faith of the Moscow model. $\left[{ }^{50}\right.$, s. $\left.264 ;{ }^{51} ;{ }^{52} ;{ }^{53}\right]$.

Many Slovaks and Ukrainians escaped repression by fleeing abroad. Emigration to Western Europe, the United States and Canada has been increasing.

In the short term, the communist government eliminated all the germs of civil society. The citizen was to become an obedient executor of the will of an "infallible" political party, which taught him how to live, what to believe, where to go, what heroes to honor. The foundation of the pyramid of communist power in the countries of "real socialism" was undoubtedly the secret police - the state security service. In the shortest possible time, it has built an extensive network of agents and staff, whose primary responsibility was to report on any manifestations of citizen dissatisfaction with the party's policies and the potential foci of organized resistance, including the church environment $\left[{ }^{54}, \mathrm{~s} .264-265\right]$.

In April 1950, the so-called Presov Cathedral was held, which in fact led to the destruction of the Greek Catholic Church for several decades. The Council adopted a notorious act on the return of Greek Catholics to the bosom of the Roman Catholic Church, authorized by the Central Committee of the Communist Party of Slovakia on the basis of a resolution of January 7, 1950. Under the influence of the Prague Spring of 1968, which was to demonstrate to the world "socialism with a human face" and promote a new liberalization of the regime, Bishop V. Hopko asked O. Dubchek, who soon became secretarygeneral of the Communist Party, to rehabilitate and restore the activities of the church. However, Government Decree No. 70 of June 13, 1968, signed by the

${ }^{50}$ Kováč D. Dejiny Slovenska / D. Kováč. - Praha: Lidové noviny, 1998. - 401 s.

${ }^{51}$ Čikeš R. Vztahy štátu a cirkvi na Slovensku / R. Čikeš. - Bratislava : Ústav pre vzt'ahy štátu a cirkvi, 2010. $-90 \mathrm{~s}$.

${ }^{52}$ Kaplan K. Stát a cirkev v Českoslovnsku v letech 1948-1953 / K. Kaplan. - Brno : Doplněk, 1993. - 121 p.

${ }_{53}$ Pešek J. Štátna moc a cirkvi na Slovensku 1948-1953 / J. Pešek, M. Barnovský. Bratislava: VEDA, 1997. - $76 \mathrm{~s}$.

${ }^{54}$ Kováč D. Dejiny Slovenska / D. Kováč. - Praha: Lidové noviny, 1998. - 401 s. 
Head of the Government of Czechoslovakia, G. Husak, banned again the activities of the Greek Catholic Church [ ${ }^{55}$, p. 124-139].

The highest authority implementing the Czechoslovakia Communist Party (CZCP) policy was established in 1949 by the State Committee on Church Affairs (SCCA), and in Slovakia by the Slovak Church Government. The "war on religious remnants" policy was elaborated and formulated in the highest party organs, in particular in the so-called Church Commission of Central Committee of the CZCP, which included six members, often referred to as the "Church Six." For many years, the Communist nomenclature, in the person of the SCCA, controlled the liturgical, pastoral, social, charitable, educational, financial and other spheres of activity of the churches. Mandatory registration of religious organizations was established, and the clergy were allowed to carry out their mission only on the basis of a state permit issued exclusively by "trustworthy", loyal to the regime persons. Illegal religious activities of individual worshipers and religious communities were severely prosecuted by state security agencies $\left[{ }^{56}\right.$, s. $\left.100-105\right]$.

Only after November 1989, when there was a "velvet" revolution, changes in the powerless position of churches and denominations have become part of social and political alterations. Churches have regained their independence, and at the same time they had great opportunities to strengthen their position in Slovak society. After the peaceful division of the Czech Republic and the Slovak Republic into two independent states, on January 1, 1993, the Slovak Republic appeared on the political map of the world. From that time on, the rights and freedoms of the individual and the citizen, their purpose, protection and guarantees have been established in it as the basic and determining criterion of the legal nature of the legislation and practice of its application. For each person preserves a certain set of natural inalienable rights, which are determined by the very fact of human existence and should be considered as a guarantee of its dignity.

According to Article 11 of the Constitution of the Slovak Republic, adopted in 1992, "international instruments on human rights and freedoms ratified by the Slovak Republic and promulgated in accordance with the law have priority over national laws, provided that international treaties and agreements guarantee a higher level of constitutional rights and freedoms" $\left[{ }^{57}\right.$, p. 446].

${ }^{55}$ Moravčiková M. Religiozita na Slovensku / M. Moravčiková, M. Cipár // Ročenka ústavu pre vzt'ahy štátu a cirkvi 1997. - Bratislava : Ústav pre vzt'ahy štátu a cirkvi, 1998. - $211 \mathrm{~s}$.

${ }^{56}$ Vaško V. Neumlcena kronika katolicke cirkve v Ceskoslovensku po druhe svetove valce / V. Vaško. - Praha, 1990. - 261 s.

${ }^{57}$ Конституція Угорської Республіки // Конституції нових держав Свропи та Азії / Упорядник С. Головатий. - К. : Українська Правнича Фундація, вид-во «Право», 1996. $612 \mathrm{c}$. 
The Constitution states that all people are free and equal in dignity and rights, and that fundamental rights and freedoms are inalienable and inviolable in the territory of the state. They are guaranteed to every person regardless of gender, race, color, language, religion and religion, political or other beliefs, national or social origin, nationality or ethnicity, property, family or other status. No one may be deprived of his legal rights, discriminated or privileged. The basic rights and freedoms of the human rights in the Constitution of Slovakia are set aside in Part II. The set of rights, freedoms and responsibilities enshrined into it is a system of constituents of personal, civil, political, social, economic, national minorities and ethnic groups, cultural and religious rights. The system of these constitutional norms defines the status of a person and a citizen in the Slovak Republic.

The international treaty, which regulates in general relations between Slovakia and the Holy See, was signed on November 24, 2000, and came into force after an exchange of instruments of ratification in the Vatican on December 18,2000 . The treaty officially entitles the Vatican through its sub-structure, the Catholic Church, to take part in the international affairs of the Slovak Republic, to provide benefits and privileges to the Catholic Church through the return to the churches of real estate, along with significant government subsidies and rights. For the Vatican it was a 184 agreement; from post-socialist countries, Poland, Hungary, Croatia, Yugoslavia, Lithuania, Estonia, Latvia, Kazakhstan and the Czech Republic have previously signed similar agreements [ ${ }^{58}$, p. 114].

The constitution and other laws of Slovakia generally protect religious freedom, although the Law on Registration of Religious Groups and Associations does some harm to smaller denominations. It determines the status of registered religious groups and contains registration requirements. To register a religious group, 20,000 of its adult members, who are either Slovak nationals or permanent residents of that country, they must submit to the Ministry of Culture an "honest declaration" that confirms their membership, knowledge of the articles of faith and basic principles of religion; it also includes identification numbers and home addresses. Registration provides the legal status necessary to perform economic functions, such as opening a bank account or leasing property, and religious functions, such as directing funeral ceremonies or accessing hospitalized peers. It should be emphasized that only officially registered communities are eligible for financial subsidies from the state. A total of 18 registered churches and religious groups received more than $€ 39$ million (about $\$ 40.1$ million) in state subsidies [ ${ }^{59}$, p. 170-184].

58 Šmid M. Priprava Základnej zmluvi medzi Slovenskou republikou a Svatou stolicou / M. Šmid // Ročenka Ústavu pre vzt'ahy štátu a cirkvi 1999. - Bratislava, 2000. - 187 s.

59 Палінчак М. М. Система державно-церковних відносин у посткомуністичній Європі: уроки для України / М. М. Палінчак // Соціогуманітарні проблеми людини : Вісник. 2012. - № 6. - С. 170-184. 
Therefore, each country of the designated region, in view of historically determined traditions, peculiarities of spiritual culture and mentality of the people, resolves the issue of state-church relations, guarantees of freedom of religion and its confessional institutionalization, tolerance of interfaith relations. Each state tries to create conditions to meet the religious needs of believers and society, and to give religious communities greater freedom of activity.

It has been proven that religious freedom is protected by the constitutions and laws of the states in question, and, as practice shows, governments generally respect religious freedom. The tendency for religious freedom to be respected by governments did not change significantly over the period under review. Governments continued to provide tax breaks and financial support to registered religious groups.

\section{CONCLUSIONS}

State - church relations of the countries of the world are an important topic of research. These relations are one of the important components of the domestic and foreign policy of the state. Thus, these relationships characterize the level, depth of relations between authorities and religious organizations, the degree of their integration (or disintegration) and cooperation. The history of church and state is almost always connected. State - church relations in the countries of Central Europe were no exception. Namely in Poland, Hungary, the Czech Republic and Slovakia.

Concerning the role of religious factor in the processes of national consolidation of society, on the basis of the above and analyzed material, it can be concluded that churches in the countries of Central and Eastern Europe (especially in Poland), even in the Soviet period, were officially recognized as an important factor in preserving national identity, in spite of all threats and dangers, they demonstrated much efforts in the field of raising public morality and patriotic education. The fact that churches, despite everything, have played a positive role in peaceful revolutions, accelerating the fall of the communist regime, confirms that totalitarian regimes always fail in their attempts to abolish religions. Moreover, anti-religious propaganda and persecution of believers indirectly worked for the authority of the churches.

At the beginning of the XXI century the church remains a reputable spiritual power in Central and Eastern Europe.

\section{SUMMARY}

The article deals with the development of state-church relations in the countries of Central and Eastern Europe. Constitutional legal and social status of church in Poland. Specificity of the Hungarian model of state-confessional relationships. Relations between the state and church in the Czech Republic. 
State-confessional relations in Slovakia. The role of the communist regime in the state-church relations of Central and Eastern Europe countries.

\section{REFERENCES}

1. Барнакевич Ю. Правовые основы гарантий свободы совести в Польской Республике: Автореф. дис. ...канд. филос. наук / Ю. Барнакевич. М., 1990. - 22 c.

2. Бураков Ю. В., Кипаренко Г. М., Мовчан С. П., Мороз Ю. М. Всесвітня історія. Новітні часи. 1945-1996 : Підручник. - К. : А.С.К., 1998. - 320 c.

3. Вандич П. Ціна свободи. Історія Центрально-Східної Європи від Середньовіччя до сьогодення / П. Вандич. - К.: Критика, 2004. - 463 с.

4. Государства и религии в Европейском Союзе (опыт государственно-конфессиональных отношений) / Под ред. Г. Робберса. М. : Институт Европы РАН, 2009. - 719 с.

5. Єленський В. Є. Релігійно-суспільні зміни в посткомуністичній Європі / В. С. Сленський // Людина і світ. - 1999. - № 7. - С. 30-33.

6. Історія Чехії очима українців : Навчально-популярне видання. Ужгород : Гражда, 2009. - 224 с.

7. Конотоп Л. Г. Головні характеристики містики: структура і зміст (в контексті релігійної антропології) / Л. Г. Конотоп, В. Л. Хромець // Антропологічні виміри езотеричної філософії. - Слов'янськ Печатний двір, 2005. - С. 43-51.

8. Конституции социалистических государств. - В 2-х т. - М. : Юридическая литература, 1987. - Т. 1; 2.

9. Конституция и основные законодательные акты Польской Народной Республики. - Пер. с польского. - М. : Политиздат, 1953. - 420 с.

10. Конституція Угорської Республіки // Конституції нових держав Свропи та Азії / Упорядник С. Головатий. - К. : Українська Правнича Фундація, вид-во «Право», 1996. - 612 с.

11. Конституція України. - К., 1997. - 80 с.

12. Конституція Чеської Республіки // Конституції нових держав Європи та Азії / Упорядник С. Головатий. - К. : Українська Правнича Фундація, вид-во «Право», 1996. - 612 с.

13. Країнознавство. Країни СНД, Європи і Північної Америки: Навчальний посібник / М. С. Дорошко, Р. А. Кривонос, В. П. Крижанівський, Н. Ф. Сербіна. - К. : Ніка-Центр, 2009. - 312 с.

14. Кріль М. М. Історія країн Центрально-Східної Свропи (кінець XX т. - початок XXI ст.) : Навчальний посібник / М. М. Кріль. - К. : Знання, 2008. - 284 c. 
15. Маріянський Я. Суспільний характер релігії / Я. Маріянський // Релігія в сучасному світі: Матеріали до курсу релігієзнавства / За ред. Г. Зімоня. - Переклад з польської Г. Теодорович. - Л. : Свічадо, 2007. 504 c. - С. $97-125$.

16. Мировой опыт государственно-церковных отношений : Учебное пособие / Под общ. ред. Н. А. Трофимчука. - М. : Изд-во РАГС, 1998. $306 \mathrm{c}$.

17. Овсиенко Ф. Г. Взаимоотношения государства и церкви в странах Восточной Европы / Ф. Г. Овсиенко // Мировой опыт государственно-церковных отношений : Учебное пособие / Под общ. ред. Н. А. Трофимчука. - М. : Изд-во РАГС, 1998. - 306 с.

18. Палінчак М. М. Система державно-церковних відносин у посткомуністичній Європі: уроки для України / М. М. Палінчак // Соціогуманітарні проблеми людини : Вісник. - 2012. - № 6. - С. 170-184.

19. Палінчак М. М. Держава i церква у постсоціалістичних суспільствах (на прикладі країн Центральної Європи та України): Монографія. - Ужгород: Поліграфцентр «Ліра», 2014. - 408 с.

20. Релігія і релігійність у посткомуністичній Європі. Цифри і факти без інтерпретацій // Людина і світ. - 1997. - Листопад-грудень. - С. 2-10.

21. Рынковский М. Государство и церковь в Польше // Государства и религии в Европейском Союзе (опыт государственно-конфессиональных отношений) / Под ред. Г. Робберса. - М. : Институт Европы РАН, 2009. 719 c. - С. $447-470$.

22. Третера И. Р. Государство и церковь в Чехии / И. Р. Третера // Государства и религии в Европейском Союзе (опыт государственноконфессиональных отношений) / Под ред. Г. Робберса. - М. : Институт Европы РАН, 2009. - 719 с. - С. 631-656.

23. Центрально-Восточная Европа во второй половине XX века. В 3-х т. - Т. 3 : Трансформации 90-х годов. - М. : Наука, 2002. - 516 с.

24. Шанда Б. Государство и церковь в Венгрии / Б. Шанда // Государства и религии в Европейском Союзе (опыт государственноконфессиональных отношений) / Под ред. Г. Робберса. - М. : Институт Европы РАН, 2009. - 719 с. - С. 97-126.

25. Юскаев Н. Х. Из опыта взаимодействия армии и церкви в некоторых восточноевропейских странах / Н. Х. Юскаев // Религия, церковь в России и за рубежом: Информационно-аналитический бюллетень. - 1998. - № 3-4. - С. 120-129.

26. Borowik I. Odbudowanie pamięci. Przemiany religijne w środkowowschodniej Europie po spadku komunism / I. Borowik. - Krakow : Zakład Wydawniczy NOMOS, 2000. - $248 \mathrm{~s}$.

27. Budapester Zeitung. - 2013. - 10 Januar. - S. 2. 
28. Cepliková M. K niektorým aspektam právnej úpravy vzt'ahov štátu a náboženských organizácii na našom územi po roku 1989 / M. Cepliková // Právny obzor: Bratislava. - 1999. - № 2. - S. 140-147.

29. Čikeš R. Vztahy štátu a cirkvi na Slovensku / R. Čikeš. - Bratislava : Ústav pre vzt'ahy štátu a cirkvi, 2010. - $90 \mathrm{~s}$.

30. Gowin Por. J. Kościół po komunizmie / J. Por. Gowin // Znak. Kraków, 1995. - S. 22-23.

31. Kaplan K. Stát a cirkev v Českoslovnsku v letech 1948-1953 / K. Kaplan. - Brno : Doplněk, 1993. - 121 p.

32. Kováč D. Dejiny Slovenska / D. Kováč. - Praha: Lidové noviny, 1998. $-401 \mathrm{~s}$.

33. Krukowski J. Problematuka osobovosci prawnej kosciola katolickiego w relacji do panstva / J. Krukowski // Roczniki teologicznokanoniczne / Kom. Red. : T-wo nauk. Katolickiego uniw. Lubelskiego. Lublin, 1978. - S. 122-146.

34. Moravčiková M. Religiozita na Slovensku / M. Moravčiková, M. Cipár // Ročenka ústavu pre vzt'ahy štátu a cirkvi 1997. - Bratislava : Ústav pre vzt'ahy štátu a cirkvi, 1998. - $211 \mathrm{~s}$.

35. Pešek J. "Katolická akcia" na Slovensku roku 1949 / J. Pešek // Historický časopis. - № 44. - 1996. - S. 47-63.

36. Pešek J. Konflikt medzi štátom a katolickou hierarchiou o prijatie a realizáciu "cirkevných zákonov" (19491951) / J. Pešek // Historický časopis. № 44. - 1996. - S. 444-470.

37. Piwowarski W. Socjologia religii / W. Piwowarski. - Lublin: Redakcja Widawnictw Katolickiego Uniwersytetu Lubelskiego, 1996. - $98 \mathrm{~s}$. Pravo Wyznaniowe. Ustawa z dnia 17 maja 1989 r. O gwarancjach wolności sumienia i wyynania. - Warszawa, 1989. - $396 \mathrm{~s}$.

38. Pešek J. Štátna moc a cirkvi na Slovensku 1948-1953 / J. Pešek, M. Barnovský. - Bratislava: VEDA, 1997. - 76 s.

39. Pietrzak M. Prawo wyznaniowe / M. Pietrzak. - Warszawa: Wydawnictwa Prawnicze PWN, 1999. - 432 s.

40. Rahner K. Atheismus / K. Rahner // Sacramentum mundi. Theologisches Lexikon für Praxis. - Bd1/Hrsg K. Rahner, A. Darlap. Freiburg, 1967. -S. 372-383.

41. Religiöser Wandel in den postcommunistischen Landern Ostund Mitteleuropas. - Wurzburg, 1998. - 176 s.

42. Šmid M. Priprava Základnej zmluvi medzi Slovenskou republikou a Svatou stolicou / M. Šmid // Ročenka Ústavu pre vzt'ahy štátu a cirkvi 1999. Bratislava, 2000. - $187 \mathrm{~s}$.

43. Staniszkis J. Post-Communism. The Emerging Enigma / J. Staniszkis. - Warszawa : Instytut Nauk Politycznych PAN, 1999. - 188 s. 
44. Szostkiewicz A. Religion after Communism / A. Szostkiewicz // Commonweal. - 09/24/99. - Vol. 126. - Issue 16. - P. 17-34.

45. Tretera J. R. Church and State in the Czech Republic / J. R. Tretera // European Journal for Church and State Research. - Peeters, Leuven. - 2001. Vol. 8. - P. 287-294.

46. Vaško V. Kronika katolickě cirkve c Českoslovnsku po druhě světove válce / V. Vaško. - Praha, 1990. - $231 \mathrm{~s}$.

47. Vaško V. Neumlcena kronika katolicke cirkve v Ceskoslovensku po druhe svetove valce / V. Vaško. - Praha, 1990. - 261 s.

48. Zenit International News Agency Daily Dispatch. - 2000. February 14, s. 2.

Information about the author:

Palinchak M. M.,

Doctor of Political Science, Professor, Dean of the Faculty of International Economic Relations, Uzhhorod National University 14, Universytetska str, Uzhhorod, 88000, Ukraine 


\section{LUGANIAN CHARACTER TWENTY YEARS LATER: NECESSARY CORRECTION}

\section{Yeremenko O. M., Kroytor A. V.}

\section{INTRODUCTION}

In the mid-nineties of the last century, one of the authors published an article "Lugansk: Mythologized Past and Possible Future", in which an attempt was made to characterize "Lugansk character as a certain socio-psychological and cultural-cultural and cultural integrity", based on the method of included observation and analysis of some features of the history of Lugansk. The changes that have taken place since these times in the socio-political, everyday and mental life of the region and caused by the events that became the epicenter of Donetsk and Lugansk, have made some adjustments as in the reality of twenty years ago as in the theoretical positions of the mentioned work. The dynamics of the historical events of the modern era are the next: over a 20-year period, changes equivalent to the much longer stages of previous historical eras can fit. At the same time, the question arises: if the essential features of a particular socio-cultural phenomenon are highlighted, will they not be constant in the flow of historical change?

The aforementioned question determines the purpose of this article: to rethink the peculiarities of "urban character", on the one hand, in the context of the problem of metaphysics of the city, on the other hand, in the context of a specific historical event that has been covered by a particular city (Lugansk).

The theoretical basis of this article, as well as the article written in 1997, will be the theory of archetypal events, outlined in the work "History as eventfulness" $"$. As a methodological basis for rethinking the provisions of the article written in 1997, the authors will allow themselves to take the method of included observation since one of the authors was partly a close observer and partly a participant of the events of 2014.

The idea of the theory of archetypical events in general is following. In the history of almost every nation, there are events that have an extremely strong influence on its mentality. They set a kind of "super-task" and "program"

${ }^{1}$ Erëmenko A. M., Sneghyrëv V. V. (1997) Lughansk: myfologhyzyrovannoe proshloe y vozmozhnoe budushhee [Lugansk: mythologized past and possible future] Drevnosty Podoncovjja, pp. 81-84.

${ }^{2}$ Erëmenko A. M. (2005) Ystoryja kak sobytyjnostj: Monoghrafyja: V 2-kh t. T. 2. [History as an Event: Monograph: In 2 volumes. Volume 2] - Lughansk: RYO LAVD, (in Ukrainian) 
the people on the efforts aimed at completing the super-task. These events can be as real as legendary, and even a real archetypical event is always mythologized to some extent (mythologization of the Trojan War in the ancient Greek epos and Greek culture as a whole).

Due to the specificity of archetypical and other important events, there is a domination of optimistic or pessimistic, major or minor motifs that determine the general tone of mentality and culture of a nation. Some events have the character of psychotraumas. (On an event as an injury, see P. Stompka's works) $)^{3,4}$

\section{Imperial and Ukrainian historiography on the establishment of the cities of Lugansk and Odessa}

Archetypical events, as well as mythological images of actors, have a long-term influence on the consciousness and the collective unconscious of social communities. It is interesting that some events are more or less adequately remembered, others in a distorted light, and others are forgotten. And it is impossible to assert that the most important events are remembered, but the least important ones are forgotten: sometimes it happens exactly the opposite.

In this aspect, the theory of archetypical events can be compared with some provisions of psychoanalysis. For example, Z. Freud emphasizes that mental trauma causes various phenomena of substitution and disguise, which do not destroy this trauma. In specific circumstances, those things, that the patient has tried to forget, come back.

Reflecting on the regularities of the collective psychology, P. Ricoeur shows that on the level of collective memory, manipulation and forgetting strategies acquire more impressive dimensions than on the level of the individual memory. Among the forms of such manipulation are memoriesscreens, uncomfortable actions, the selectivity of stories about the historical past, manifesting itself in silences, shifting of accents, refigurations of participants of the action, and other forms. In Ricoeur's opinion, fundamental events form a certain "redundancy of memory" in nations, which resonates with Freud's analysis of the attraction to repeat ${ }^{5}$.

In the context of the theory of archetypical events, the controversy around the date of Lugansk's foundation is representative. Traditionally, such date is considered November 14, 1795. On this day Catherine II signed a decree

${ }^{3}$ Shtompka P. (2001) Kuljturnaja travma v postkommunystycheskom obshhestve [Cultural trauma in a post-communist society] Socyologhycheskye yssledovanyja, no. 2, pp. $23-38$.

${ }^{4}$ Shtompka P. (2001) Socyaljnoe yzmenenye kak travma (statjja pervaja) [Social change as trauma (article one) SOCYS., no. 1, pp. 6-16.

${ }^{5}$ P. Ricoeur (2004) Pamjatj, ystoryja, zabvenye [Memory, history, forgetting]. Moskva: Yzdateljstvo ghumanytarnoj lyteratury. (in Russian) 
"On the establishment of a foundry at the Lugansk River in Donetsk County and on the establishment of a scrap of coal found in that country".

The "town-based" meaning of the decree of 14.11 .1795 is denied by the local historians, who are guided by the Ukrainian historical narrative. They note that the decree is not yet a city, and the factory itself is not yet a city. The Ukrainian narrative emphasizes that the plant was built near the village of Kamenny Brod, which was founded by the Zaporizhzhia Cossacks in the mid18 th century ${ }^{6}$.

It is interesting that there is a similar conflict between the Ukrainian and the Great-Power Russian narrative regarding the problem of founding Odessa. There is a well-known controversy in the historical scientific community about the "genuine" foundation of Odessa. Supporters of the Ukrainian historical narrative object to the traditional date of 2 September 1794, when, according to the decree of Catherine II of 27 May 1794, the construction of a military harbour began. By the way, the style of the Empress's decrees regarding the foundation of a military factory on the Lugan river and a military harbor on the Black Sea coast is very similar: "Respecting the privileged position of Khadjibei at the Black Sea and the associated advantages, we recognized the need to arrange a military harbor there with a merchant's quay". (Compare it with the above-mentioned decree of November 14, 1795).

A group of Ukrainian historians postpones the date of foundation of Odessa to 1415 and even in older times. In 1415, for the first time appeared a mention of the port of Kachibey (Khajibey, Kochubey, Kujabey, etc.), which belonged to the Grand Duchy of Lithuania and was later conquered by the Ottoman Empire. There are also attempts to further "ancient" the history of Odessa, indicating that in the XIII-XIV centuries on the territory of the city there was a Genoese shipyard called Ginestra ${ }^{7}$.

So, the controversy around the foundation of Odessa has not faded in recent years and is especially active on the eve of the "City Day" celebration. This discussion has become influenced by the media, involving politicians and actively using political discourse. As D. Yakovlev and O. Eremenko note, "Political discourse, unlike many other discourses, is the most massive. It is the political discourse that is most fully transmitted by modern media, while political actors actively use communication technologies, which make it possible to fight for power the most effectively. On the one hand, it may seem that political discourse dominates others or is an autonomous sphere at all; but on the other hand, it is in political discourse that borrowing from other

${ }^{6}$ Zakharchenko R. S. (2007) Kam'janyj brid [The stone ford] Encyklopedija istoriji Ukrajiny: u 10 tomakh Tom 4 [Encyclopedia of Ukrainian History: in 10 volumes. Volume 4.

${ }^{7}$ Ystoryja osnovanye Odessy [History foundation of Odessa] Aghenstvo "Tudoj - Sjudoj" Retrieved from: https://tudoy-sudoy.od.ua/istoriya-osnovanie-odessy/ (accessed 11 February 2020) 
discourses, appealing to the discourse of other social groups, and citing and interpreting them are the most visible ${ }^{8}$.

Certainly, for a long time historical science developed in line with the generally accepted imperial Russian historiography. It was characterized by interpreting the beginning of the history of all cities, villages and towns of the Northern Black Sea coast from the end of the XVIII century. Therefore, for example, the majority of settlements in the Odessa region are considered to have been founded between the end of the XVIII century and the beginning of the XIX century, in particular, it concerns the city of Odessa, that officially celebrates its foundation in 1794 .

In particular, the site of the city on the eve of the "City Day" announced: "September 2, 2019 Odessa will celebrate the 225th anniversary of the founding of the city. On the occasion of the memorable date by the order of Odessa Mayor, the plan of measures to celebrate the Day of Odessa has been approved"'.

Most historians, however, have been chronicling the city since the founding of the fortress of Kotsyubey. In particular, A. Bachinskaya notes: "In historical science, the first written mention of any settlement is considered to be the beginning of history. Based on this principle, the scientist Alexander Boldyrev convincingly proved that in the case of Odessa it is 1415 , when information about the port of Kachibey, or Khajibey, first appeared in written sources. In his fundamental work "The History of Poland" the $15^{\text {th }}$-century chronicler Jan Dlugosz paid attention to the "Port of Kochibey". Talking about the events of 1415 , he wrote in particular: "... at that time came to the Polish king Wladyslaw ambassadors of the patriarch and Greek emperor with a letter and tin bulls, they were honored, and the Turks tortured and oppressed them in every way; they need generous help with grain. Wladyslaw, the Polish king in holy compassion, documentary certifies help. He gives and generously presents requests for the amount of grain that they need to get in his royal port of Kochubeyes. $^{10}$

This date is not ignored by the authors of the textbook "Odessa is my hometown" A. Levchishen, A. Pospelov who notes that "For the first time

${ }^{8}$ Eremenko A., Yakovlev D. (2019). "My dialektiku uchili ne po Gegelyu". Filosofiya v zerkale politicheskoy propagandy: popytka antropologicheskogo podkhoda ["We studied dialectics not according to Hegel". The philosophy in the mirror of political propaganda: an attempt to the anthropological approach] Current problems of philosophy and sociology, no. 24, pp. 10-23. https://doi.org/10.32837/apfs.v0i24.885 (accessed 11 February 2020)

${ }^{9}$ Denj ghoroda. Proghramma [City day. Program] Oficijnyj sajt mista Odesa Retrieved from: https://omr.gov.ua/ua/announce/216868/(accessed 11 February 2020)

${ }^{10}$ Bachynsjka O. Ghoncharuk T. (2014) ODESA ta ODJeSA - "ne dve boljshye raznycy" [ODESA and ODESA - "not two big differences"] Tyzhdenj ua [Week ua]. (electronic journal) Retrieved from: https://tyzhden.ua/Society/120970 (accessed 11 February 2020) 
Kochubey mentioned in the chronicle "History of Poland" in 1415 (here the author of "History" Ian Dlugosz was wrong for 7 years; in fact, the events he described took place in 1422). Dlugosz writes that there was a "port" in Kochubey, which belonged to Lithuanian prince Vitovt and Polish king Jagailo. From here, the rulers of the Polish-Lithuanian Duchy send on merchant ships a batch of grain to Constantinople, which was besieged by the Turks. But by the second half of the XV century, the power of the Duchy of Lithuania in these lands is weakening, and the shores of the current Gulf of Odessa again come to desolation. Remains of the Lithuanian castle of Kochubeyes, the travelers, passing by, saw only in the ruins. Thus, in 1578 Martin Bronevsky writes about its ruins "Kachibey castle fortress was like a landslide that is washed by a wide lake, and is located by the sea". Turkish traveler Evliya Celebi in 1657 reports: "If the fortifications are restored at least a little, the area will become inhabited again, and the road will became safe" $"$.

In this manual it was also noted that "in July 1709, on the ruins of Kochubey, near "a tiny Tatar village", the Swedish King Charles XII and the Ukrainian hetman Mazepa spent the night, heading after the defeat at Poltava under the protection of the Turkish fortress of Bender ... Only in $1765 \ldots$ on the eve of another war with Russia, the Turks began to repair the old medieval castle. However, the restored fortress, named Yeni-Dunya, looked miserable in comparison with such Turkish strongholds of the Black Sea region as Ochakov, Bendery or Izmail. Ukrainian Cossacks called the new castle a "krepostca". ${ }^{12}$

However, in contrast to the mentioned authors, which slightly reduces, perhaps deliberately, the importance of settlement around the fortress and the fortress itself. A. Bachinskaya and T. Goncharuk indicate that around the fortress developed a number of Cossack settlements, in particular, the researchers note: "In the second half of the XV century Kachibey, as well as the entire surrounding Black Sea coast were captured by the powerful Ottoman Empire and its ally Crimean Khanate. In the new owners it eventually got the name "Khajibey" (although in the documents until the second half of the XVIII century it was also used by Kachibey, Kuchubey, Kujabey, etc.), and later YeniDunya (from Turkic "New World"). And around the fortress - Kochubey Tatarstan, or Khan Ukraine, where settlers and farmers, mainly Ukrainians from the nearest territories, paid "masters" Tatars (represented by their "Hetman of Dubossary" and Khan Ukraine) a tenth of the harvest. The Ukrainian peasants

${ }^{11}$ Levchyshyna O., Pospjelov A. Odesa - moje misto ridne. Navchaljnyj posibnyk dlja uchniv 8-kh klasiv [Odessa is my hometown. Tutorial for 8 grade students]. Retrieved from: http://odessa.gutenbergz.com/menu.html (accessed 11 February 2020)

${ }^{12}$ Levchyshyna O., Pospjelov A. Odesa - moje misto ridne. Navchaljnyj posibnyk dlja uchniv 8-kh klasiv [Odessa is my hometown. Tutorial for 8 grade students]. Retrieved from: http://odessa.gutenbergz.com/menu.html (accessed 11 February 2020) 
to live in Ganshchina - as the people called the Khan's Ukraine - were better than under the lordship... In addition, more and more of them, in particular the citizens of Zaporizhya, began to engage in all sorts of crafts in the Black Sea"13.

On date 1415 accented on her site popular in Odessa travel agency "Tudoy-sudoy" noting: “... the history of Odessa began long before Catherine ... In the 13-14 centuries, when the Northern Black Sea was ruled by Tatars, on the place of today's Odessa was the parking of Genoese ships. Ancient Portolans (nautical charts) brought to us its name - Ginestra (in Italian is called Droch - a bushy plant with yellow flowers, especially common in the Black Sea steppes). As it is known, before the end of the 14th - beginning of the 15th century, the North-Western Black Sea Coast passed from the possession of the Tatars to the Grand Duchy of Lithuania. It was in the $15^{\text {th }}$ century that the first mention in written sources of the settlement of Kachibey, the nearest ancestor of Odessa, was made. When Kachibey appeared, it is not precisely determined and his name was changed many times: Kotsyubeev, Kachibey, Kujabei, Hajibei, Hajibei, Ajibei...". ${ }^{4}$

Interesting is A. Boldarev's argument in favor of the beginning of the chronology of Odessa since 1415, which notes that "Was Odessa founded in 1794? No, it wasn't. This year, there was no city with this name in nature. For the first time, the name "Odessa" in connection with the settlement on the Black Sea coast began to figure in early 1795 . Interestingly, all attempts of prerevolutionary historians to find a legal document that would indicate the renaming of Khajibey to Odessa, were in vain - it was not found"15.

In addition, the historian adds: "In any case with the renaming of Khajibey, the main thing to remember is that in 1794 the settlement with the name of Odessa did not exist. In that case, what was founded on August 22, 1794? It turns out that Khajibey was founded. Wait. It turns out that Khajibey hadn't existed before? Wasn't Khajibey stormed by troops of Russian Empire in 1774 and I789? Wasn't it not in Khajibey where the Russian pledge was placed after a successful assault? To establish Khajibey in Khajibey is as impossible as to establish Ishmael in Ishmael, Moscow in Moscow and Paris in Paris! Let's imagine for a moment that Mordvinov's project would have taken advantage over Deribas's project and the port would have been built hot in Khajibey but in Ochakov, what then - Ochakov would have had to be considered as "founded"

${ }^{13}$ Bachynsjka O. Ghoncharuk T. (2014) ODESA ta ODJeSA - "ne dve boljshye raznycy" [ODESA and ODESA - "not two big differences"] Tyzhdenj ua [Week ua]. (electronic journal) Retrieved from: https://tyzhden.ua/Society/120970 (accessed 11 February 2020)

${ }^{14}$ Ystoryja osnovanye Odessy [History foundation of Odessa] Aghenstvo "Tudoj - Sjudoj" Retrieved from: https://tudoy-sudoy.od.ua/istoriya-osnovanie-odessy/ (accessed 11 February 2020)

15 Boldyrjev O. ODESI-600. Istorychnyj narys. [ODESSA-600. Historical sketch]. Retrieved from: https://storinka-m.kiev.ua/article.php?id=955 (accessed 11 February 2020) 
in 1794 and not at the turn of XIV-XV centuries, as it was in reality and with what everyone agrees?"16

It should be noted that even the "Great Soviet Encyclopedia" avoids direct reference to 1794 as the year of founding the city of Odessa, noting: "Odessa was founded on the site of the pope Kachibey, the first mention of which refers to 1415 . In the 15th century the settlement was destroyed by the Turks, and then it appeared under the name of Khachibey. By Yassky peace treaty of 1791 Khadjibey became part of Russia. In August 1794 in Hajibey by project of engineer F. Devollan under the leadership of A. V. Suvorov and Deribas (see Ribas I.) began to create a naval harbor. In 1795 Khadjibey was renamed to Odessa..."

But the politically engaged history of the founding of the city is presented in the collection "History of towns and villages of the Ukrainian SSR. In particular, the obliquely collected dates of the founding of Odessa clearly stated: "It was at this time, on the place of today's Odessa, a settlement Kachibey (Kotsyubiyiv, Kachikhlenov, Hajibey, etc.) appeared. The first mention of it dates back to 1415 when Kachibey was already a relatively significant port from which grain was exported. There was a large castle on the territory of Kachibey. The remains of the castle were preserved until the middle of the XVIII century ... In the second half of the XVIII century, the Turkish government began construction of Yeni Dunya Fortress near Kacibey. The Ukrainians, the Greeks, the Armenians and others started to settle the city again. At the suggestion of the great Russian commander A. V. Suvorov construction of the fortress in Hadjibey started in 1793. In 1794 works on construction of the new city began. This year is considered the time of the foundation of Odessa. May 27, 1794 there appeared "the highest decree", which stated: "Respecting the favorable position of Khajibey at the Black Sea and the associated benefits, we recognized the need to arrange a military harbour with a merchant's quay. The management of all these works was entrusted and in the future was carried out by Suvorov, one of the main founders of Odessa. The specially created expedition led by IM Deribass and a talented engineer F. Devolan should build a harbor and a city in 5 years. In 1795, Hajibey was renamed into Odessa under the name of the Greek colony Odessa, which once existed near the mentioned territory. The foundation of Odessa was one of the consequences of centuries of the struggle of Ukrainian and Russian peoples for the return of their native Black Sea lands". ${ }^{18}$ However,

\section{${ }^{16}$ Ibid.}

17 Boljshaja sovetskaja encyklopedyja 3-e yzdanye [The Great Soviet Encyclopedia 3 Edition] Retrieved from: http://bse.uaio.ru/BSEOLD/bse3.htm (accessed 11 February 2020)

${ }^{18}$ Istorija mist i sil Ukrajinsjkoji RSR [History of cities and villages of the Ukrainian SSR].

Retrieved from: http://ukrssr.com.ua/odeska/viniknennya-i-rozvitok-mista-odesa (accessed 11 February 2020) 
as we can see even in this source it is stated that the city was within the fortress of Khajibey and until 1794. It should also be noted that the very fact of the existence of a Greek colony with this name remains very questionable.

The analysis of textbooks on the history of Ukraine for general educational institutions showed rather a fragment of mentioning both the creation of Kochubey fortress and the events connected with the assault of Khadjibey fortress by Cossack and Russian troops in 1794. In particular, the textbook "The History of Ukraine" for $7^{\text {th }}$-grade pupils, written by A. Gisem, states: "New victories allowed Vitovt to further expand the borders of his state. Having reached an agreement with the owner of the Golden Horde Tokhtamysh, he began to develop the Black Sea coast between the Dnieper and Dniester. Forts began to be built in Khadjibei (now Odessa), Caravul, Belgorod (Ackerman, now Belgorod-Dnestrovsky), Chornogorod, Dashev (now Ochakov). It also contributes to the formation of the independent Crimean Khanate". ${ }^{19}$

The author of the textbook on the history of Ukraine for the 8th grade $\mathrm{V}$. Vlasov only in a general paragraph concerns the history of the city of Odessa, noting that the last decades of the XVIII century became a time of active colonization of the south of Ukraine and the emergence of new cities. The list of such cities also includes Odessa. Thus, the author of the textbook also begins the chronicle of Odessa in fact from the end of the century. ${ }^{20}$

The authors of the textbook History of Ukraine for the 8th grade G. Shvydko, P. Chernobai still connect the construction of Odessa with Catherine II, which is consistent with the version of the origin of Odessa set out in "History of cities and villages of the Ukrainian SSR. In particular, the authors note: "Mainly based on existing settlements on the southern outskirts of the empire, the government laid down new cities, or renamed the old settlements. Then on the basis of Cossack settlements were laid the provincial city of Yekaterinoslav, port cities Kherson, Nikolaev, Odessa" ${ }^{21}$. Even in the manual for the preparation of EPLL it was noted that 1794 is the date of "the founding of the city on the site of the settlement of Hajibey (from 1795 Odessa) ${ }^{22}$.

${ }^{19}$ Ghisem O. (2015) Istorija Ukrajiny : pidruchnyk dlja 7 kl. zaghaljnoosvit. navch. zakl. [History of Ukraine: a textbook for the 7th form of secondary schools institutions]. Teronpilj: Navchaljna knygha - Boghdan. (in Ukrainian)

${ }^{20}$ Vlasov V. (2016) Istorija Ukrajiny : pidruchnyk dlja 8 kl. zaghaljnoosvit. navch. zakl. [History of Ukraine: a textbook for the 8th form of secondary schools institutions]. Kyjiv: Gheneza. (in Ukrainian)

${ }^{21}$ Shvydjko K., Chornobaj P. (2016) Istorija Ukrajiny : pidruchnyk dlja $8 \mathrm{kl}$. zaghaljnoosvit. navch. zakl. [History of Ukraine: a textbook for the 8th form of secondary schools institutions]. Kyjiv: Gheneza. (in Ukrainian)

${ }^{22}$ Vlasov V., Kuljchycjkyj S. (2014) Istorija Ukrajiny: kompleksne vydannja [History of Ukraine: a comprehensive publication] Kyjiv: Litera. (in Ukrainian) Retrieved from: 
The question arises why, having the publicly available data on the history of Odessa, the majority of Odessa citizens still consider 1794 to be the beginning of chronology of the city. The answer to this question was given very clearly by A. Bachinskaya, noting: "It is difficult to find in Odessa and not only there a man who would not have heard about how much Catherine II did for the city. The Empress is glorified as the founder and benefactor of the city, a person who almost saw in it the future center of the region and through actions paved the way to prosperity. There is also a widely known story that the Empress has changed the male name "Odessos" to the female version of the name of the ancient Greek city "Odessa". And although the first historians are inclined to the fact that it is only a legend and no facts it has not confirmed it yet, this beautiful fairy tale is still known to the citizens of Odessa better than the real events in the history of their cities ${ }^{23}$.

Moreover, for the majority of Ukrainians, things that were included in history textbooks, school curricula, and even more, that do not dissonate the generally accepted opinion, which was formed under the pressure of historical circumstances and does not contradict the historical paradigm that emerged during the Russian Empire turns into a perfect historical fact that does not require proof. Analyzing the textbooks of history of Ukraine for the interpretation of the history of the founding of the city of Odessa showed that even in the conditions of modern Ukrainian educational system the imperial historical tradition of founding the city of Odessa is preserved. Thus, it is worth agreeing that "the transformation of the post-communist system of education can not be successful without constant attention to the process of indoctrination, which involves revealing the ideologizing of education, the dangers of resacralization of the choice and deconstruction of the canon through the demonstration of historical alternatives to religious choice" ${ }^{24}$. And in this case, it concerns not only the date of foundation of the city but also the process of selecting its name in 1795 .

This is confirmed by the preservation of the imperial symbolism in the names of the city streets. And although most of these names were removed during the Soviet period according to the toponymy of Odessa, almost all of

https://erudyt.net/pidgotovka-do-zno/istoriya-ukraini-pidgotovka-do-zno/istoriya-ukrajinykompleksne-vydannya-zno-2014.html (accessed 11 February 2020)

${ }^{23}$ Bachynsjka O. Ghoncharuk T. (2014) ODESA ta ODJeSA - "ne dve boljshye raznycy" [ODESA and ODESA - "not two big differences"] Tyzhdenj ua [Week ua]. (electronic journal) Retrieved from: https://tyzhden.ua/Society/120970 (accessed 11 February 2020)

${ }^{24}$ Kroytor A., Yakovlev D., Aleksentseva-Timchenko K. (2019) 'Apostles' of indoctrination: ideological peculiarities of representation of religious choice in the secondary education (based on analysis of expert interviews) Ideology and Politics, no. 2 (13), pp. 127-146. Retrieved from: https://ideopol.org/wpcontent/uploads/2019/12/ (accessed online 31 December 2019) 
them were returned during the period of independence of Ukraine, in particular, more than 60 street names of the city today have their origin from the times of the Russian Empire and coexist quite organically with the names of the Soviet period and those received after the declaration of independence of Ukraine, in particular during the process of decommunization.

Mythologized Catherine II is a popular folklore character as in Odessa as in Lugansk. The monument to Catherine the Great in Odessa is known to everyone. The Lugansk media from time to time raised the issue of erecting a monument to the Russian Empress as the "highest" founder of the city. Odessa is widely known for the legend that it was the Empress who changed the male name "Odessos" to the female version of "Odessa"25. Among Luhansk residents, there is a legend that the alleged name of a tributary of the Seversky Donets - the river Aidar appeared after the Empress exclaimed: "Ai, dar (a gift)!", - in response to the sturgeon presented to her, caught in the waters of the river. Actually, Ekaterina II never visited the territory of present Lugasnka area, and the name "Aidar" is obviously of Turkic origin.

Odessa and Lugansk are extremely different cities, and the character of Odessa is significantly different from that of Lugansk. But, strangely enough, a closer look at history discovers a kind of "karmic bonds" of the seaport on the Black Sea coast and the military plant on the Lugan River.

Originally, the working settlement, founded by decree of Catherine, was called "Lugansk factory". This name lasted till Alexander III, whose decree from 03.09.1888 "About merge of village Kamenny Brod and settlement Lugansk foundry factory in district city Lugansk" marked the appearance of the city in full sense of the word.

If not going into polemics, to recognize the programming importance of the foundation of the Lugansk plant, it should be noted two important details. 1. A military factory was founded, the main task of which was to produce cannons and cores for the Black Sea Fleet. By the way, on the Borodino field, the Lugansk cannons also boasted. 2. There was founded a public, that is, a state factory. The original workers for this factory were "craftsmen" from other provinces of the empire: Lipetsk, Tula, from the Urals factories.

The factory, designed for the production of weapons, forms a militaristic program of the city community. The state form of ownership stimulates the features of Etatist paternalism. Resettlement of the original inhabitants of the settlement determines the absence of "roots", a significant historical tradition.

Some features of the city's appearance in architectural, psychological and value aspects are comparable with the highlighted features.

${ }^{25}$ Bachynsjka O. Ghoncharuk T. (2014) ODESA ta ODJeSA - "ne dve boljshye raznycy" [ODESA and ODESA - "not two big differences"] Tyzhdenj ua [Week ua]. (electronic journal) Retrieved from: https://tyzhden.ua/Society/120970 (accessed 11 February 2020) 
Some foreign observers point out a strange feature of Lugansk from their point of view: a high "specific weight" of the blocks in comparison with the streets. Sometimes a perplexing question sounds: "Does Lugansk have streets or only blocks"? Apparently, the "block" system is connected with the development of housing stock by enterprises or in connection with the needs of enterprises. Toponyms known to Lugansk citizens are "Southern Quarters", "Eastern Quarters" (in the vernacular of "Quarter" - specific Lugansk jargon), "OR Plant Town", "OR Plant Settlement", etc.

It should be noted that under the Soviet regime, 44 out of 70 Lugansk factories were directly or indirectly connected with the military-industrial complex.

To understand the mentality of Lugansk people it makes sense to pay attention to the following seemingly inconspicuous, but significant detail. Lugansk is mentioned several times in the Ukrainian history textbooks for the 9 th grade of general education institutions in the general context. For example, in the textbook "History of Ukraine for 9th grade," A. Strukevich, in the context of the Crimean War-related events, notes that "it was to a large extent the Ukrainian military industry that provided the army with military supplies. Lugansk factory increased the production of shells almost fourfold, Shostkins gunpowder factory produced six times more gunpowder - almost as much as the other factories in Russia" 26.

The next mention of Lugansk in this textbook is the thesis that "At the end of the century the first transport engineering enterprises - Kharkiv and Lugansk steam locomotive plants - appeared in Ukraine. By 1900, they had produced 233 steam locomotives" 27 .

Lugansk is mentioned a little bit more in the Ukrainian history textbook for $10^{\text {th }}$-grade pupils. The city is mentioned in the context of the struggle of the UNR troops with the Bolsheviks. In particular, the authors of the textbook A. Hysem and A. Martyniuk note: "Having suffered a defeat in Kiev, the Bolsheviks were not going to give up power in Ukraine. During November, they managed to seize power in Lugansk". The next mention in the textbook Luganskaia is a report on the implementation of the GOELRO plan in 1920 in Ukraine and the commissioning of the power plant in Lugansk. In this textbook, in the context of the story about the beginning of the liberation of Ukraine from Nazi forces, it is stated: "The first settlement liberated on December 18, 1942, was 218 division VI village Pivnevka Voroshilovgrad (now Lugansk) region. Further in the text, once again mentioned Lugansk, namely: "On March 15,

${ }^{26}$ Strukevych O. (2017) Istorija Ukrajiny : pidruchnyk dlja 9 kl. zaghaljnoosvit. navch. zakl. [History of Ukraine: a textbook for the 9th form of secondary schools institutions]. Kyjiv: Ghramota. (in Ukrainian)

${ }^{27}$ Ibid. 
1943 German troops captured Kharkiv again, and on March 18 - Belgorod. Under the control of the Soviet troops remained only the north of Voroshilovgrad and the eastern part of Kharkov region" ${ }^{28}$. This textbook also contains a photograph showing the removal of the bells from the temple in Lugansk in 1929.

Much more about Lugansk is mentioned in the Ukrainian history textbook for 11th-grade pupils. In particular, the authors of the textbook V. Vlasov and S. Kulchitsky posted a photo with the image of the diesel locomotive and a comment: "The diesel locomotive of the TEZ No. 2068 series, built at the Voroshilovgrad (Lugansk) Diesel Locomotive Plant. Diesel locomotive FEZ became the most massive series in the network of Soviet railways ${ }^{29}$.

This textbook contains a fragment of an interview with Nikolai Rudenko on the establishment of the Ukrainian Helsinki Group and a meeting of some of its representatives in the Lugansk region. Luhansk region is also mentioned quite fragmentarily in the textbook during the presentation of the material dedicated to the "orange revolution," in particular: "During the meeting, representatives of the opposition said that in Donetsk region Yanukovych "drew" 1 million 200 thousand votes for himself, in Luhansk - up to 500 thousand, in Mykolaiv, Kherson, Odessa, Zaporizhzhya and Dnipropetrovsk combined -1 million ... Immediately after the announcement of the falsified results of the second round of the CEC, Yushchenko appealed to the Supreme Court of Ukraine through an authorized representative, demanding that the results of the vote in Donetsk and Luhansk regions be declared invalid due to massive violations of law and distortion of the results of the public will expression" ${ }^{30}$.

Lugansk region is also mentioned in the paragraph devoted to the armed aggression of Russia against Ukraine in this context: "It began with the seizure of administrative buildings in Lugansk and Donetsk regions, which allowed terrorists to take power in many cities of the region. In this paragraph there is a chronological line with the date and the inscription: "April 2014. Occupation by terrorists in Donetsk and Lugansk. In addition, the authors note, "In Lugansk, on April 6, they captured the regional branch of the SBU ... However, the situation in Donetsk and Luhansk oblasts was getting hotter. On 12 April, a group of SBU officers and Alpha units were ambushed near Slavyansk. The

${ }^{28}$ Ghisem O. Martynjuk O. (2018) Istorija Ukrajiny : pidruchnyk dlja 10 kl. zaghaljnoosvit. navch. zakl. [History of Ukraine: a textbook for the 10th form of secondary schools institutions]. Kharkiv: Ranok. (in Ukrainian)

${ }_{29}$ Vlasov V. Kuljchycjkyj S. (2019) Istorija Ukrajiny : pidruchnyk dlja 11 kl. zaghaljnoosvit. navch. zakl. [History of Ukraine: a textbook for the 11th form of secondary schools institutions]. Kyjiv: Litera. (in Ukrainian)

${ }^{30}$ Ibid. 
authors also mention Lugansk and Lugansk region from the following angle: "By the end of April 2014 on the territory of many settlements of Donetsk and Lugansk regions the militants captured dozens of state infrastructure objects and carried out armed attacks on units and parts of the Ukrainian law enforcement agencies. April 27th was announced to "Lugansk National Republic" 31 .

Another mention of Lugansk region in the textbook happens when describing the events related to the signing of the Minsk agreements, in particular, the authors point out: "The protocol mentioned the obligations of Ukraine to ensure by law the "special status" of certain districts of Donetsk and Luhansk regions. However, this notion was blurred. The monitoring of the ceasefire regime by the OSCE was not concretised either... As a result of long negotiations, the leaders of the Quartet agreed on an immediate and comprehensive ceasefire in some areas of Donetsk and Lugansk regions ... On the territory uncontrolled by Ukraine in Lugansk and Donetsk regions of the Russian Federation pulled down a large number of weapons, in particular 558 tanks" ${ }^{\prime 2}$.

In general, the Ukrainian history textbook for grade 9 mentions Lugansk and Lugansk region twice, and the textbook for grade 10 mentions four times. But the textbook for the 11th grade mentions Lugansk and Lugansk region fifteen times. In this context, it should be noted that "constructing the political reality of the future is impossible without a historical interpretation and categorization of the past" ${ }^{\prime 3}$. After all, the historical memory of certain social groups and society as a whole affect the spatial orientation of the population and its self-identity, which is expressed in particular in the mentality of not only Lugansk or Odessa residents, but also the population of other regions of the country.

\section{2. "Lugansk mentality" today: formation and features}

Lugansk flourished in the $60 \mathrm{~s}-70 \mathrm{~s}$ of the twentieth century. True, it was "Soviet socialist" prosperity, far from the standards of the prosperity of developed capitalist countries, but a Soviet citizen who was not familiar with these standards was quite satisfied with it. Lugansk prosperity had both a material aspect and a "quasi-spiritual" one. The material aspect was expressed

31 Vlasov V. Kuljchycjkyj S. (2019) Istorija Ukrajiny : pidruchnyk dlja $11 \mathrm{kl}$. zaghaljnoosvit. navch. zakl. [History of Ukraine: a textbook for the 11th form of secondary schools institutions]. Kyjiv: Litera. (in Ukrainian)

${ }^{32}$ Ibid.

${ }^{33}$ Jakovlev, D., \& Krojtor, A. (2018). Istorija vyboru ta vybir istoriji. Relighijnyj vybir Kyjeva u pidruchnykakh Ukrajiny. [Choice History and History Choice. Kyiv's religious choice in Ukrainian textbooks] Reghionaljna polityka: istorija, polityko-pravovi zasady, arkhitektura, urbanistyka: zb. nauk. pracj. Kyjiv - Ternopilj: Beskydy, pp. 38-44. 
in the comparative abundance of Lugansk shop counters (compared, for example, with the Rostov region). The football sensation of 1972 - gold medals of Lugansk "Zarya" in the USSR championship - can be considered a conditionally spiritual success. By the way, "Zarya" was the first team not from the capital city, which won the championship of the Union.

Looking back at the recent past from the "height" of the current years, we cease to be surprised by strong nostalgia for the Soviet stagnation, enveloping the souls of most Lugansk people. By the way, this nostalgia was an important psychologically-axiological factor that contributed to "hot support" of separatist moods. If you "scrape" the Donbas separatist, you will find in his soul nostalgia for stagnation.

In the article of 1997, the following characteristics of the mentality of a typical Lugansk resident were highlighted:

1. Paternalism.

2. Militarism.

3. The combination of paternalism and militarism gave rise to authoritarianism. Discipline and order were a priority in Lugansk's value system. Moreover, the Lugansk resident preferred not self-discipline, but discipline brought from outside by the "firm hand". One of the manifestations of the authoritarian discipline of Lugansk people is a high overcoming power, typical for a typical representative of the Lugansk community. And it is not so much the active force of overcoming someone else's will, unfavorable circumstances, obstacles, etc., as the passive power of undergoing, the irresistible force of obedience, the ability to demolish everything, to endure everything, to survive in spite of everything. The Lugansk man is not so much brave as hardy. The average Lugansk resident will ignore the difficulties that will seem unbearable to a Kievan or Odessa citizen.

4. Internationalism. For a Lugansk resident, class affiliation is much more important than national affiliation. The average Lugansk resident, as well as the entire Donbasian, is a "natural Marxist". Lugansk scientist A. N. Litvinov expressed an idea worthy of attention: despite the ridicule of intellectuals, "a new community of people - the Soviet people" was still formed, however, in a separate region. And this region is Donbass. However, the events of the Donbas conflict make adjustments in particular to the Donbas mentality. Until 2014, the issue of national identity was not very worrying the hearts of Lugansk citizens. It seems that from now on it will find a "hot response" in the "Donbass soul".

5. Conservatism, cautious perception of the new.

6. The prevalence of industrial and economic mentality over humanitarian mentality. In the eyes of a typical Lugansk resident "real" work is physical labor in heavy industry. 
7. Ingenuity, absence of a significant tradition. With the presence of a rather pronounced regional patriotism with elements of "Donbas pride" contrasts with the motive of "faraway lands" present in the mentality of the Donbas people. Deep down, the Lugansk resident understands that there are, to put it mildly, not very comfortable conditions, but his efforts are usually aimed not at improving these conditions, but at finding the best ones wherever they are. Luganchanin, so to speak, is "easy to move up": it is easier for him to move than to "cultivate his garden".

The following objection is raised with regard to the features of the Lugansk character we have identified: to what extent are these features relevant to the Lugansk people? Many of these features, to a greater or lesser extent, were inherent in the mass citizen of the Soviet Union, that is, the very "scoop" that came off the pages of brilliant journalism A. Zinoviev. Didn't we describe the "scoop" instead of the typical Lugansk resident of the typical homo soveticus, the enfant terrible of post-perestroika liberal consciousness?

The rebuke is undoubtedly fair. Let's put forward the following counterargument as an excuse. Indeed, a Donbasian, a Lugansk resident in particular, is a typical representative of a Soviet man. But, first of all, it follows from this that the features of the psychological image of a Soviet man are characteristic features of a Lugansk resident. Second, some social groups turn out to be the most representative for understanding the essential features of the larger social community of which they are a part. It is in these social groups that the essential features of the social community of which they are a part are most vividly displayed. And we assume that the people of Donbas, particularly the people of Lugansk, are not just representatives, but, so to speak, classical representatives of homo soveticus.

The events of 2014-2019 undoubtedly require adjustments to the Lugansk concept. But these adjustments consist not only in clarifying and amending the stated provisions. Obviously, a number of provisions of the 1997 article are correct; some provisions have explanatory and predictive force regarding the event level of the Donbas conflict, as well as the peculiarities of the Donbas mentality.

First of all, in the context of such peculiarities of Lugansk character as paternalism, militarism and authoritarianism, the stable sympathies of Lugansk residents towards Putin's Russia and personally towards V. Putin are quite understandable. In the minds of many Lugansk residents, current Russia is a natural continuation of the lost Soviet Union. Its power (perhaps, it seems), its military might, the revival of militarism, both in ideology and in practice, - all these features of Putin's Russia are very attractive to a typical Lugansk resident. $\mathrm{He}$ perceives peacefulness as a weakness; he is impressed by healthy aggression. 
The conservatism of the Lugansk people that we have noted partially explains the effectiveness of one of Putin's propaganda features, namely the emphasis on the value of a stable order and the intimidation of change. In general, intimidation is a very effective manipulative strategy with regard to conservative consciousness. At the same time, it becomes indifferent to what is presented as threatening factors: Bandera, Maidan, gay and lesbian Europeans, American imperialism, or some mythical "fascists" who grow up to be a symbol of universal evil. First of all, it is indifferent whether these pseudosubstantiations constructed by propaganda efforts pose a real threat; secondly, it is indifferent whether they are connected. The main thing is to connect them with the pernicious and sinful "novelty" that is looming on the unfortunate "Donbas people" from the foggy faraway unknown West.

Next: Paternalism undoubtedly forms a passive social character. It is worth noting the impressive passivity of the Luhansk people during the events of spring-summer 2014. Euromaydan in Lugansk, as a rule, did not gather more than two hundred or three hundred people; in rare cases, it gathered more than five hundred participants. This is in the case of half a million inhabitants of the city. Of course, this passivity is partly due to the obvious or hidden sympathies of the majority of city dwellers for Putin's Russia and, consequently, for the "Novorossiya" project and other separatist ideologies. (It must be said that for many Luhansk residents, separatism as such was of no value - the region's fake independence was thought to be the initial stage in the process of entering Russia).

Still, a considerable number of patriotic citizens lived in Lugansk. So why didn't they provide an impressive mass of Euromaydan? Their prevailing mood expressed well the thought that was often heard from their lips in conversations with the authors: "This is none of our business. We believed that the authorities should put things in order".

However, the passivity of the Luhansk people should not be exaggerated. Emigrant observations of the psychological image of the inhabitants of other cities of Ukraine, supported by the observations of the Donbas migrants, who found shelter in these cities, convince us that civil passivity is a problem for a significant part of our population. According to many Lugansk resettlers, if the goal was to provoke separatist sentiments in many cities of eastern Ukraine, it would be no less successful than in Donbas. On the other hand, the facts of the separatists' defeat in Kharkiv, Dnipropetrovsk and Odesa contradict this opinion. The question remains open.

It should be noted that in the shadow of the masters a rather strong intellectual layer of Lugansk humanitarian intelligentsia was formed. It is interesting that one of the characteristic features of the mentality of this layer is a rather pronounced metaphysical character. The reflection on the events of 
2014-2015 in Donetsk was reflected in the work of Donetsk intellectuals called "Metaphysics of Donetsk" "34. Unfortunately, Lugansk emigration cannot boast of such work. But we have a slightly different meaning in mind: we are not talking so much about the metaphysics of Lugansk, but about the metaphysics of the Lugansk people. Metaphysical connotations are inherent in Lugansk's philosophical discourse, both professional and, to an even greater extent, amateur. A Lugansk man, so to speak, is "by nature a metaphysicist". (It should be explained that in the whole previous context we used the word "metaphysics" in the Aristotelian sense - as "first philosophy"). The dominant historical and philosophical discourse in contemporary philosophical thinking is not at all the same in Lugansk. The Lugansk lover of philosophy will certainly be impressed by the speaker's historical-philosophical erudition at a discussion club or symposium. But it will not impress him to the core. The Lugansk man will say something like that: "It's all good, of course, but what's your own teaching?" The Luganian humanitarian prefers his philosophy to historicalphilosophical professionalism, even if it turns out to be dilettantish.

By the way, in this particular case we can see a remote and controversial, but, in our opinion, a kind of mental foundation for sympathy for imperialism, Eurasianism and all kinds of "duginism": the Lugansk intellectual is convinced that political practice should be rooted in some kind of metaphysical foundation.

\section{CONCLUSIONS}

The issue of the Donbas identity remains controversial. Not only in journalism, but also in scientific research, there was an opinion about the Donbas people as a special socio-cultural and even ethnic community. Naturally, in the consciousness of the Donbas residents, there was a more or less pronounced sense of regional identity, however, as in the consciousness of the residents of any region. In connection with the events of the Donbas conflict, this feeling became stronger. It would be premature to believe that this feeling marks the emergence of a new national community. But, as they say, "the process has gone". If the current state of affairs in Donbas is put on hold, the sense of regional identity will increase and in the future may lead to the formation of some kind of Donbas quasi-nationality. It should be explained that the mentioned process will involve, first of all, the residents of the occupied territories.

I would like to draw attention to some peculiarities of the mentality, in our opinion, of the neglected strata of the Donbas population - the settlers. This

${ }^{34}$ Ghurzhy V., Bilokobyljsjkyj O., Dodonov R., ta in. (2012) "Metafyzyka Donecka" [Metaphysics of Donetsk] Retrieved from: https://donbasstudies.org/book/metafizika-donetska/ (accessed 11 February 2020) 
group is, undoubtedly, quite diffuse. Social status, economic well-being, world outlook and political values of representatives of this group are quite different. Nevertheless, in our opinion, it is possible to speak about the Donbas migrants as an integral community. One of the spiritual and psychological factors in the constitution of the integrity of this group can be considered a peculiar feature of the mentality of immigrants - the obvious or implicit sacralization of Donetsk and Lugansk in the nostalgic consciousness of emigrants. Such processes to a certain extent characterize the consciousness of any emigrant group.

Earlier, one of the authors put the Luhansk citizens metaphor of "new postmodern Jews" into circulation. In the consciousness of some part of the Lugansk emigrants, the abandoned city acquires the features of a kind of sacral symbol, the lost "promised land," the "wall of crying," to which one must return. It is possible to assume that similar moods take place among the immigrants from Donetsk. Will the Donbasians preserve their spiritual community or will they dissolve into the crucible of the modern geopolitical brew without a trace? If they do, the modern world will acquire a kind of "invisible" community with high creative potential.

If it was necessary to characterize the essence of what is happening in Donbass in one word, we would certainly choose the word "tragedy". The events of the Donbas conflict resemble the ancient Greek tragedy almost in the purity of the genre. Let's remind the classical definition of the best tragic fable that Aristotle gives: in a well-compiled story (fable) it is necessary that the change in it takes place not from misfortune to happiness, but on the contrary, from happiness to misfortune and not because of viciousness, but because of a great mistake of a man such as it is said [not distinguished by "neither virtue nor righteousness"], and if it is not, it is rather better than worse.

The Donbas drama reproduces this fable with amazing accuracy. Like most of the representatives of homo sapiens, the Luhansk citizens were rather the best than the worst people, and they were not distinguished by either special virtue or righteousness. And they voluntarily, on their own naivety, and partly driven by lowly passions, committed acts that led them from happiness to misfortune, and some to death. In anticipation of the boundless and seemingly inevitable happiness, they opened their brains to a deadly bullet.

Honorable spectators! Cry, weep, sympathize, and most importantly become better, watching the Tragedy of Donbass.

\section{SUMMARY}

The specificity of Lugansk mentality in the context of Donbas political consciousness (mentality) is considered in the article. The influence of "archipelago events" on the historical development of social communities and the peculiarities of historical memory regarding the founding of the cities of 
Odesa and Lugansk in the context of historical discourse that dominates the worldviews of the residents of these cities. There fore archiptypical events are able to program the value system of individual communities, forming a relevant supremacy of its life activity. It is proved that the peculiarity of the Lugansk mentality is the tendency to authoritarianism, paternalism, internationalism, conservatism and the absence of a significant cultural and historical tradition. It is anslized the influence of these traits as a metal-psychological basis of modern conflict in the Donbass.

\section{REFERENCES}

1. Bachynsjka O. Ghoncharuk T. (2014) ODESA ta ODJeSA - "ne dve boljshye raznycy" [ODESA and ODESA - "not two big differences"] Tyzhdenj ua [Week ua]. (electronic journal) Retrieved from: https://tyzhden.ua/ Society/120970 (accessed 11 February 2020)

2. Boldyrjev O. ODESI-600. Istorychnyj narys. [ODESSA-600. Historical sketch]. Retrieved from: https://storinka-m.kiev.ua/article.php? id=955 (accessed 11 February 2020)

3. Boljshaja sovetskaja эncyklopedyja 3-e yzdanye [The Great Soviet Encyclopedia 3 Edition] Retrieved from: http://bse.uaio.ru/BSEOLD/bse3.htm (accessed 11 February 2020)

4. Denj ghoroda. Proghramma [City day. Program] Oficijnyj sajt mista Odesa Retrieved from: https://omr.gov.ua/ua/announce/216868/ (accessed 11 February 2020)

5. Eremenko A., Yakovlev D. (2019). "My dialektiku uchili ne po Gegelyu". Filosofiya v zerkale politicheskoy propagandy: popytka antropologicheskogo podkhoda ["We studied dialectics not according to Hegel". The philosophy in the mirror of political propaganda: an attempt to the anthropological approach] Current problems of philosophy and sociology, no. 24, pp. 10-23. https://doi.org/10.32837/apfs.v0i24.885 (accessed 11 February 2020)

6. Erëmenko A. M. (2005) Ystoryja kak sobutyjnostj: Monoghrafyja: V 2-kh t. T. 2. [History as an Event: Monograph: In 2 volumes. Volume 2] Lughansk: RYO LAVD, (in Ukrainian)

7. Erëmenko A. M., Sneghyrëv V. V. (1997) Lughansk: myfologhyzyrovannoe proshloe y vozmozhnoe budushhee [Lugansk: mythologized past and possible future] Drevnosty Podoncovjja, pp. 81-84.

8. Ghisem O. (2015) Istorija Ukrajiny : pidruchnyk dlja $7 \mathrm{kl}$. zaghaljnoosvit. navch. zakl. [History of Ukraine: a textbook for the 7th form of secondary schools institutions]. Teronpilj: Navchaljna knygha - Boghdan. (in Ukrainian) 
9. Ghisem O. Martynjuk O. (2018) Istorija Ukrajiny : pidruchnyk dlja $10 \mathrm{kl}$. zaghaljnoosvit. navch. zakl. [History of Ukraine: a textbook for the 10th form of secondary schools institutions]. Kharkiv: Ranok. (in Ukrainian)

10. Ghurzhy V., Bilokobyljsjkyj O., Dodonov R., ta in. (2012) "Metafyzyka Donecka" [Metaphysics of Donetsk] Retrieved from: https://donbasstudies.org/book/metafizika-donetska/ (accessed 11 February 2020)

11. Istorija mist i sil Ukrajinsjkoji RSR [History of cities and villages of the Ukrainian SSR]. Retrieved from: http://ukrssr.com.ua/odeska/viniknennya-irozvitok-mista-odesa (accessed 11 February 2020)

12. Jakovlev, D., \& Krojtor, A. (2018). Istorija vyboru ta vybir istoriji. Relighijnyj vybir Kyjeva u pidruchnykakh Ukrajiny. [Choice History and History Choice. Kyiv's religious choice in Ukrainian textbooks] Reghionaljna polityka: istorija, polityko-pravovi zasady, arkhitektura, urbanistyka: zb. nauk. pracj. Kyjiv - Ternopilj: Beskydy, pp. 38-44.

13. Kroytor A., Yakovlev D., Aleksentseva-Timchenko K. (2019) 'Apostles' of indoctrination: ideological peculiarities of representation of religious choice in the secondary education (based on analysis of expert interviews) Ideology and Politics, no. 2 (13), pp. 127 - 146. Retrieved from: https://ideopol.org/wpcontent/uploads/2019/12/ (accessed online 31 December 2019)

14. Levchyshyna O., Pospjelov A. Odesa - moje misto ridne. Navchaljnyj posibnyk dlja uchniv 8-kh klasiv [Odessa is my hometown. Tutorial for 8 grade students]. Retrieved from: http://odessa.gutenbergz.com/ menu.html (accessed 11 February 2020)

15. P. Ricoeur (2004) Pamjatj, ystoryja, zabvenye [Memory, history, forgetting]. Moskva: Yzdateljstvo ghumanytarnoj lyteratury. (in Russian)

16. Shtompka P. (2001) Kuljturnaja travma v postkommunystycheskom obshhestve [Cultural trauma in a post-communist society] Socyologhycheskye yssledovanyja, no. 2, pp. $23-38$.

17. Shtompka P. (2001) Socyaljnoe yzmenenye kak travma (statjja pervaja) [Social change as trauma (article one) SOCYS., no. 1, pp. 6-16.

18. Shvydjko K., Chornobaj P. (2016) Istorija Ukrajiny : pidruchnyk dlja $8 \mathrm{kl}$. zaghaljnoosvit. navch. zakl. [History of Ukraine: a textbook for the 8th form of secondary schools institutions]. Kyjiv: Gheneza. (in Ukrainian)

19. Strukevych O. (2017) Istorija Ukrajiny : pidruchnyk dlja $9 \mathrm{kl}$. zaghaljnoosvit. navch. zakl. [History of Ukraine: a textbook for the 9th form of secondary schools institutions]. Kyjiv: Ghramota. (in Ukrainian)

20. Vlasov V. (2016) Istorija Ukrajiny : pidruchnyk dlja $8 \mathrm{kl}$. zaghaljnoosvit. navch. zakl. [History of Ukraine: a textbook for the 8th form of secondary schools institutions]. Kyjiv: Gheneza. (in Ukrainian) 
21. Vlasov V. Kuljchycjkyj S. (2019) Istorija Ukrajiny : pidruchnyk dlja $11 \mathrm{kl}$. zaghaljnoosvit. navch. zakl. [History of Ukraine: a textbook for the 11th form of secondary schools institutions]. Kyjiv: Litera. (in Ukrainian)

22. Vlasov V., Kuljchycjkyj S. (2014) Istorija Ukrajiny: kompleksne vydannja [History of Ukraine: a comprehensive publication] Kyjiv: Litera. (in Ukrainian) Retrieved from: https://erudyt.net/pidgotovka-do-zno/istoriyaukraini-pidgotovka-do-zno/istoriya-ukrajiny-kompleksne-vydannya-zno2014.html (accessed 11 February 2020)

23. Ystoryja osnovanye Odessy [History foundation of Odessa] Aghenstvo "Tudoj - Sjudoj" Retrieved from: https://tudoy-sudoy.od.ua/istoriyaosnovanie-odessy/ (accessed 11 February 2020)

24.Zakharchenko R. S. (2007) Kam'janyj brid [The stone ford] Encyklopedija istoriji Ukrajiny: u 10 tomakh Tom 4 [Encyclopedia of Ukrainian History: in 10 volumes. Volume 4.

\section{Information about the authors:} Yeremenko O. M., Prof. dr hab., Head of the Department of Philosophy, National University Odessa Law Academy 23, Fontanska str., Odessa, 65009, Ukraine ORCID ID: orcid.org/0000-0002-2922-0643

Kroytor A. V., $\mathrm{PhD}$, Department of Political Science, National University Odessa Law Academy 23, Fontanska str., Odessa, 65009, Ukraine ORCID ID: orcid.org/0000-0003-4652-7441 
NOTES 
Publishing house "Liha-Pres"

9 Kastelivka str., Lviv, 79012, Ukraine

44 Lubicka str., Torun, 87-100, Poland

Printed by the publishing house "Liha-Pres"

Passed for printing: August 31, 2020.

A run of 150 copies. 